\title{
Norway: Staff Report for the 2009 Article IV Consultation
}

The following documents have been released and are included in this package:

- $\quad$ The staff report, prepared by a staff team of the IMF, following discussions that ended on November 23, 2009, with the officials of Iceland on economic developments and policies. Based on information available at the time of these discussions, the staff report was completed on January 5, 2010. The views expressed in the staff report are those of the staff team and do not necessarily reflect the views of the Executive Board of the IMF.

- $\quad$ A Public Information Notice (PIN)

- A statement by the Executive Director for Norway.

The policy of publication of staff reports and other documents allows for the deletion of market-sensitive information.

Copies of this report are available to the public from

International Monetary Fund • Publication Services

$70019^{\text {th }}$ Street, N.W. • Washington, D.C. 20431

Telephone: (202) 623-7430 • Telefax: (202) 623-7201

E-mail: publications@imf.org Internet: http://www.imf.org

\section{International Monetary Fund Washington, D.C.}


INTERNATIONAL MONETARY FUND

NORWAY

\title{
Staff Report for the 2009 Article IV Consultation
}

Prepared by the Staff Representatives for the 2009 Consultation with Norway

Approved by Juha Kähkönen and David Marston

January 5, 2010

\begin{abstract}
Discussions: Oslo, Norway, November 12-23, 2009. The mission met with Finance Minister Sigbjørn Johnsen, Norges Bank Governor Svein Gjedrem, FSA Director General Bjørn Skogstad Aamo, other senior officials, and representatives from labor and business organizations, financial institutions, and academia. Mr. Bergo (OED) participated in some of the meetings. A press conference was held at the end of the mission. The mission's concluding statement was published on November 23, 2009 and can be found at: http:/www.imf.org/external/np/ms/2009/112309.htm
\end{abstract}

Staff team: Ms. Iakova (head), Messrs. Meier, Surti, and Tulin (all EUR).

Political situation: Norway's center-left government coalition won a second term in September 2009 general elections.

Executive summary: Norway's economy has returned to growth after a comparatively short and mild recession. The financial sector has withstood the crisis well, although credit risks remain elevated. The discussions focused on policies to support a sustained economic recovery and preserve the stability of the financial system. Staff advocated: (i) a gradual withdrawal of fiscal and monetary stimulus as the economic recovery takes hold; (ii) reducing the structural nonoil deficit to the fiscal target within the current term of Parliament; (iii) effective steps to curb large inflows into sickness and disability benefit schemes; (iv) further strengthening of the prudential framework for the financial sector. The authorities agreed with the mission on the key policy priorities.

Context of past surveillance: In line with past Fund advice, the authorities combined tighter monetary policy with relative fiscal restraint to curb demand pressures during the preLehman boom in the domestic economy. By contrast, past policy advice on addressing the problem of very high enrollment for sickness and disability benefits has not yet led to a lasting solution.

Exchange rate: Norway has a freely floating exchange rate. The exchange system is free of restrictions on the making of payments and transfers for current international transactions other than restrictions notified to the Fund in accordance with Decision No. 144-(52/51).

Official development assistance: Norway has continued to provide generous ODA, amounting to 0.9 percent of national income in 2008 and 1 percent in 2009. 


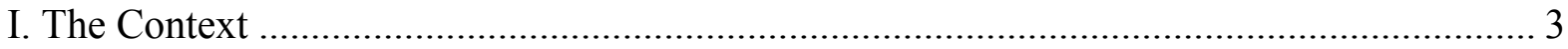

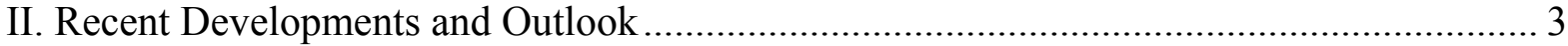

A. Households and Corporations ………………….................................................... 7

B. Financial Institutions .......................................................................................... 10

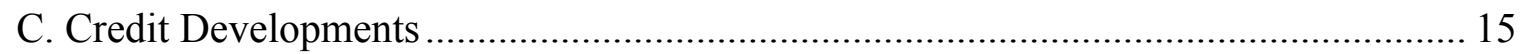

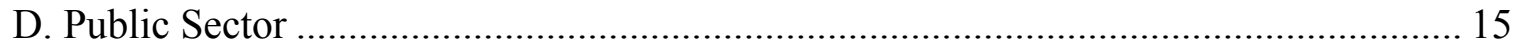

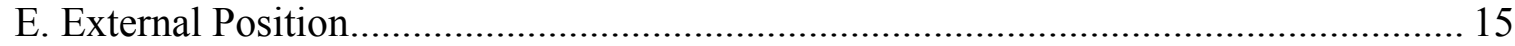

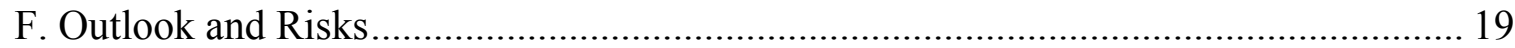

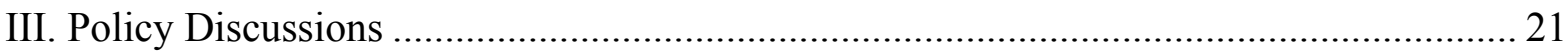

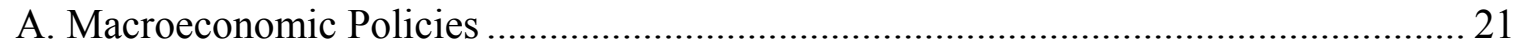

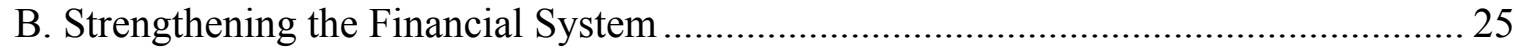

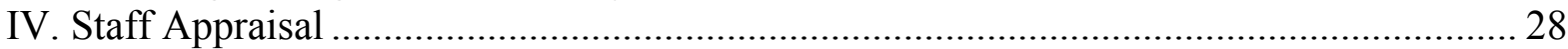

Figures

1. Norway's Relative Performance During the Crisis.......................................................... 4

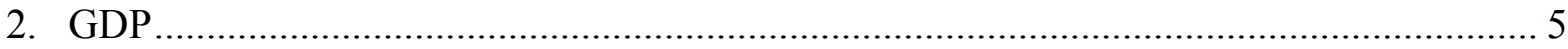

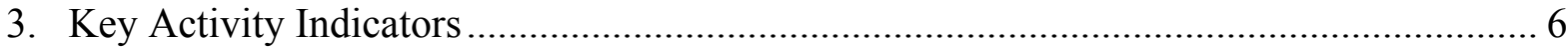

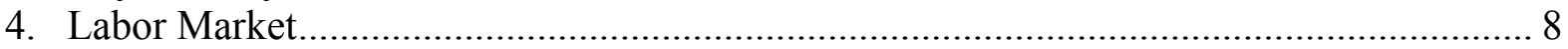

5. Household and Corporate Sector ................................................................................. 9

6. Nordic Banks' Relative Performance: 2003-08 ……................................................. 12

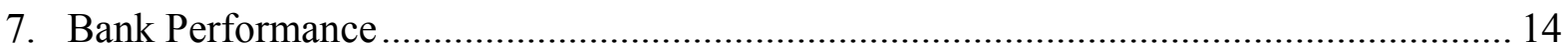

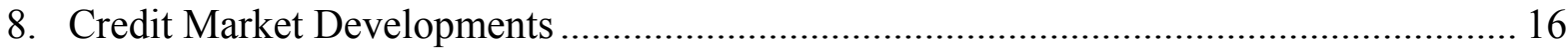

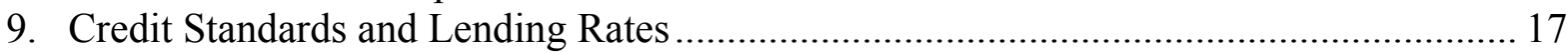

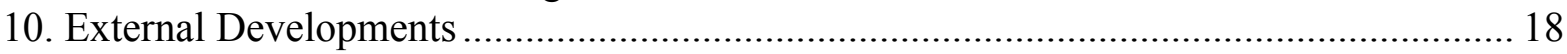

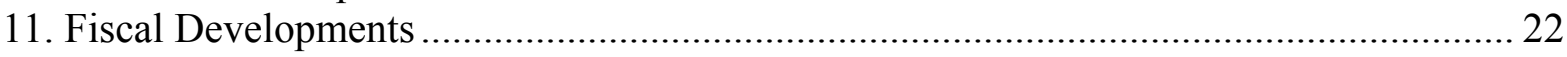

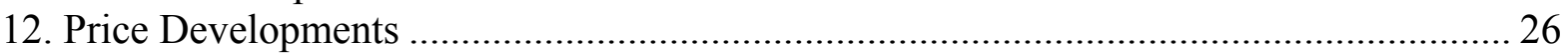

Tables

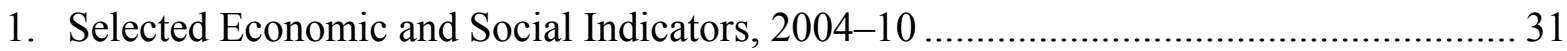

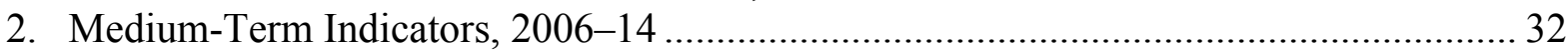

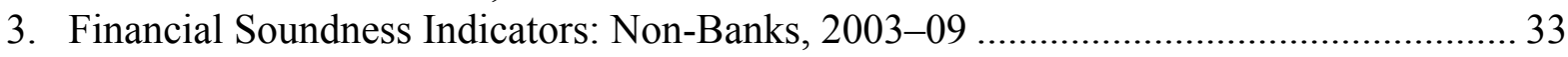

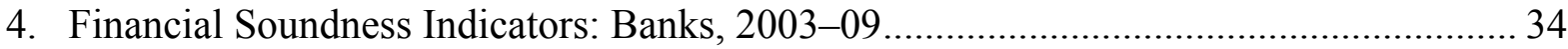

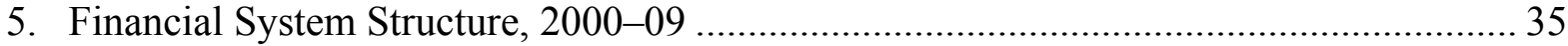

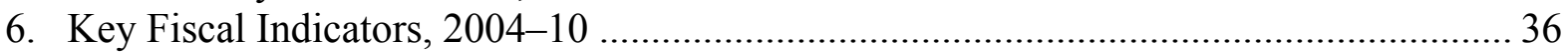

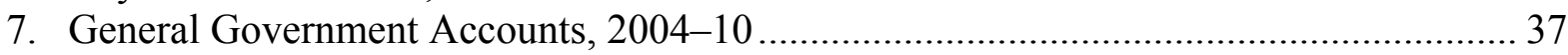

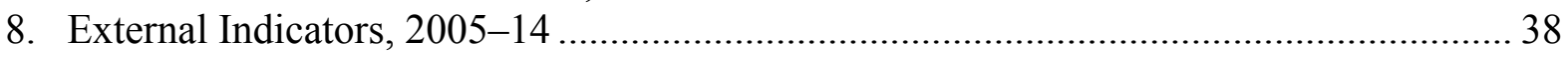

Boxes

1. Structure and Cross-Border Linkages of the Norwegian Banking System....................... 13

2. Real Effective Exchange Rate Assessment..................................................................... 20

Annexes

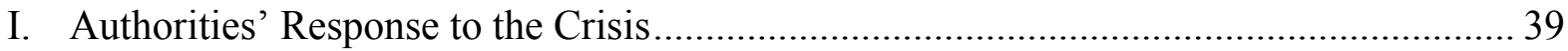

II. Collapse Then-Calm Today: What Has Changed Since the 1988-93 Banking Crisis? . 41

III. Spillovers from the Euro Area to Norway-The Role of Financial Shocks..................... 44

IV. Recent Stress Tests of Norwegian Banks' Portfolios ...................................................... 46 


\section{The ConteXT}

1. Economic growth has resumed after a relatively mild recession. Norway was affected by the global financial crisis, but less severely than most other European economies. After three quarters of declining output, mainland GDP already returned to growth in the second quarter of 2009. Unemployment remains very low and key short-term indicators point to a continued recovery. Norway's resilience has been underpinned by substantial macroeconomic stimulus, buoyant activity in the offshore hydrocarbon sector ${ }^{1}$, high public sector employment, limited dependence on the hardest-hit segments of global manufacturing, and the relative stability of the domestic financial sector (Figure 1).

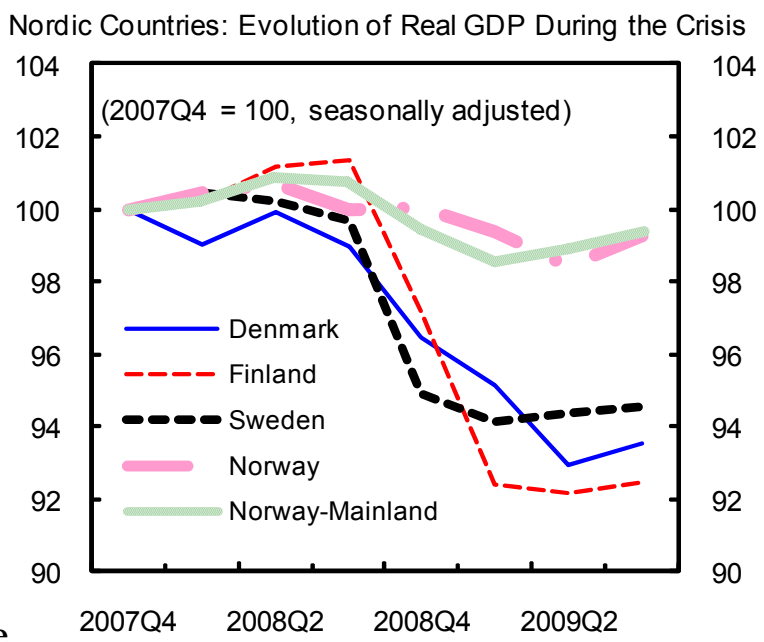

Sources: Haver Analytics; and IMF staff calculations.

2. The mission's discussions focused on policies to ensure a sustained economic recovery and preserve the stability of the financial system. In the near term, the main task is to manage the exit from very loose macroeconomic policies as the recovery takes hold. While the overall policy stance should remain supportive, the relatively limited degree of spare capacity calls for a gradual withdrawal of stimulus. Looking further ahead, Norway faces the challenge of maintaining strong economic performance under potentially more difficult conditions. In recent years, the economy has benefited from significant terms-oftrade gains, rising asset prices, benign demographics, and low global macroeconomic volatility. Going forward, these favorable trends cannot be taken for granted. To maintain the economy's flexibility and resilience, it is crucial that competitiveness remain strong, fiscal space be regained to deal with future shocks and aging-related spending pressures, and the prudential framework be strengthened to preserve a stable financial system.

\section{RECENT DEVELOPMENTS AND OUTLOOK}

3. The economy entered the crisis from a very strong cyclical position. Brisk oil sector activity, rising asset prices, and rapid credit growth had boosted domestic demand. The unemployment rate dropped to 2.5 percent, despite a rise in labor force participation and strong net immigration. Rapid wage growth and surging commodity prices pushed inflation well above the 2.5-percent target by early 2008 (Tables 1 and 2). Output growth slowed sharply only in the second half of 2008 as the global crisis intensified (Figures 2 and 3).

\footnotetext{
${ }^{1}$ Large offshore oil and gas reserves have underpinned Norway's rise to become one of the world's richest economies since exploitation began in 1971. The sector contributed an average 27 percent to total value added in the economy during 2005-08, accounting for nearly half of total exports and about one-third of general government revenue. A large part of the revenue is saved in a sovereign wealth fund which invests the money in international financial markets.
} 
Figure 1. Norway's Relative Performance During the Crisis

Norway experienced a less pronounced recession than most industrialized economies, including its Nordic neighbors.

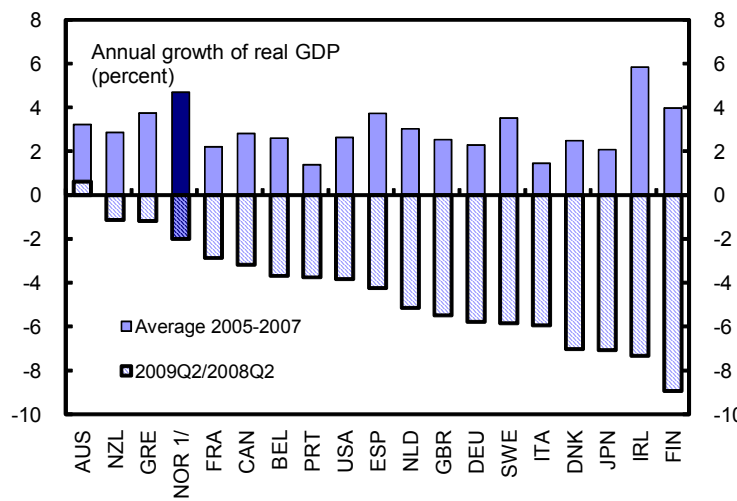

Meanwhile, fiscal policy also provided strong stimulus, centered around discretionary increases in spending.

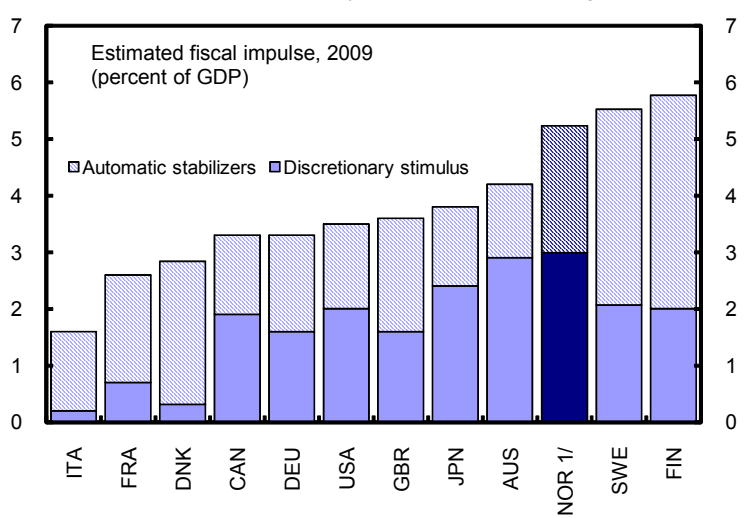

...and limited dependence on manufacturing.

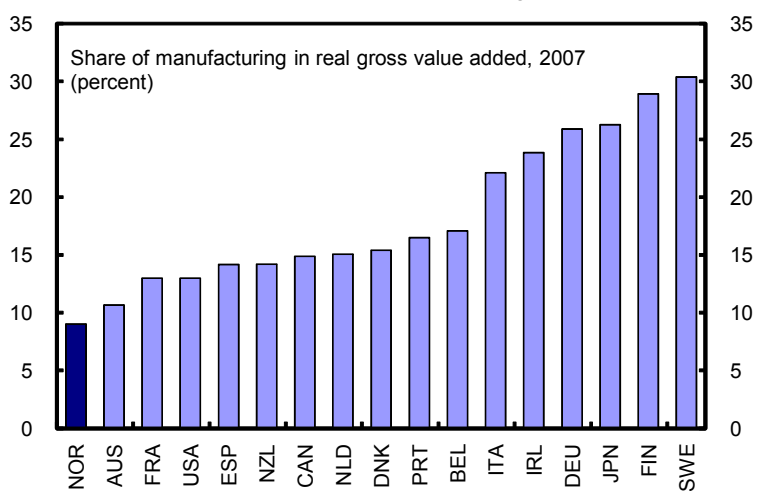

Large policy rate cuts proved very effective by providing quick relief to borrowers, given the dominance of variable-rate mortgages.

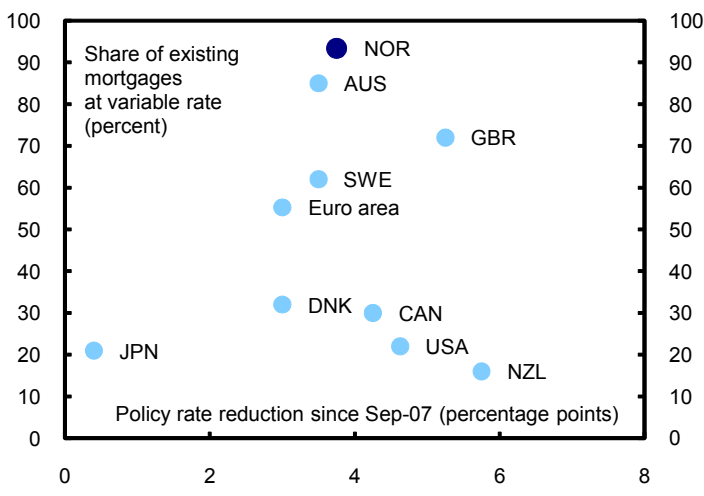

The economy's resilience has been further underpinned by high public sector employment..

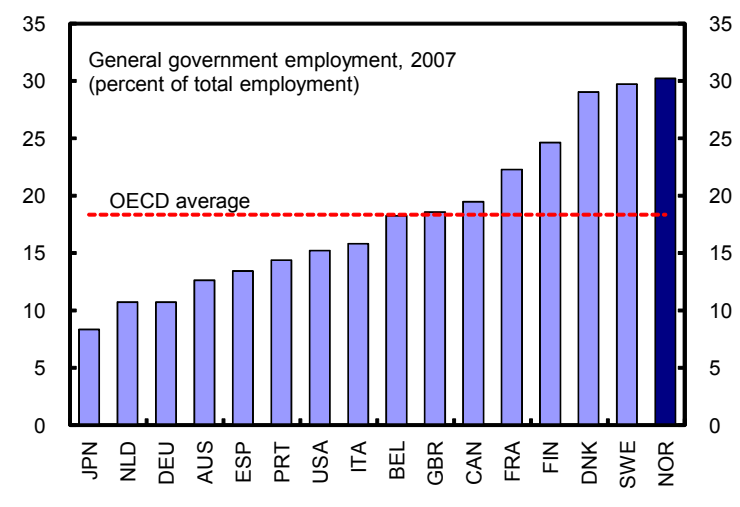

The financial system, in turn, has remained profitable, despite the vulnerabilities arising from strong previous credit growth.

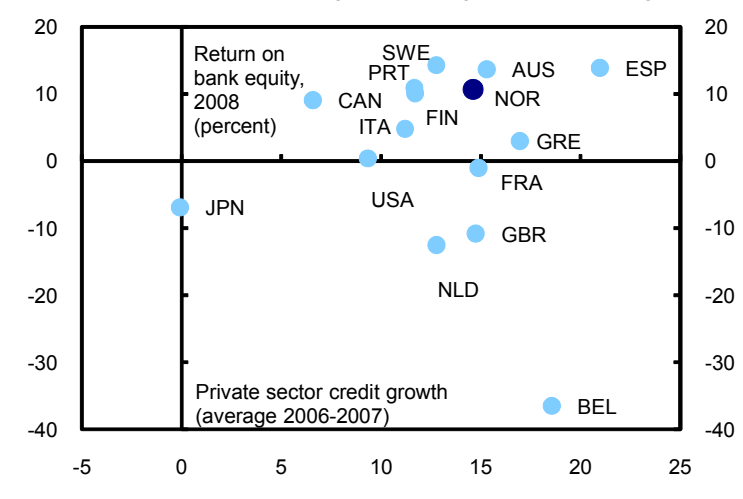

Sources: IMF, Global Financial Stability Report and International Financial Statistics; OECD; and Haver Analytics. 1/ Refers to mainland economy. 
Figure 2. Norway: GDP

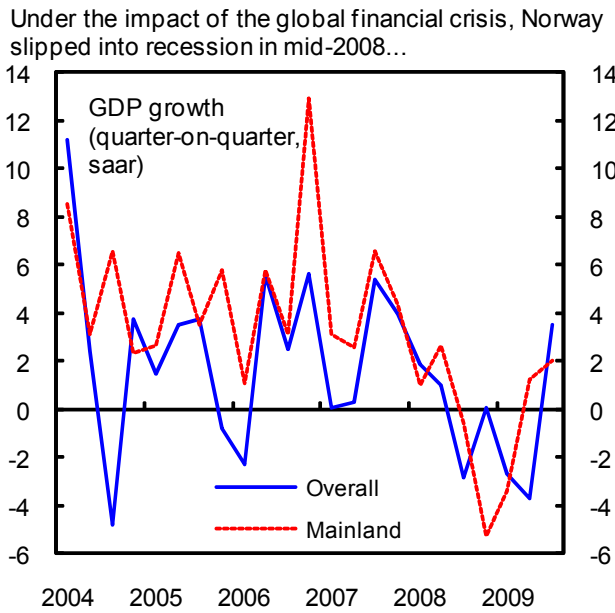

On the production side, the downturn was led by manufacturing and construction, whereas the dominant services and offshore sectors held up relatively well.

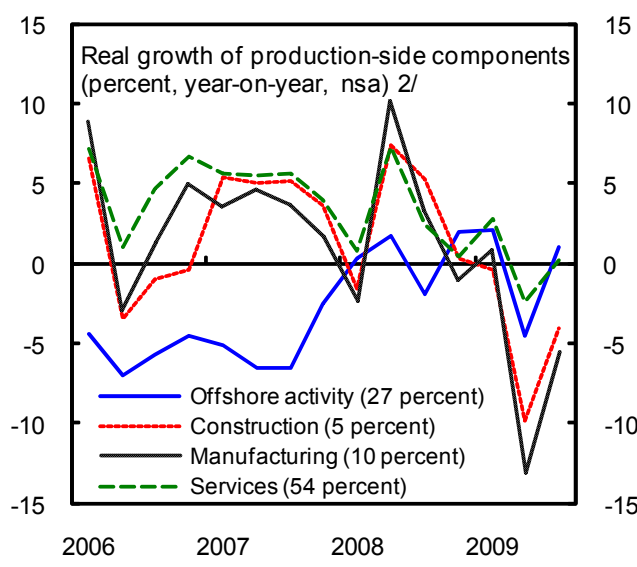

...aided by strong government spending and a recovery of private consumption.

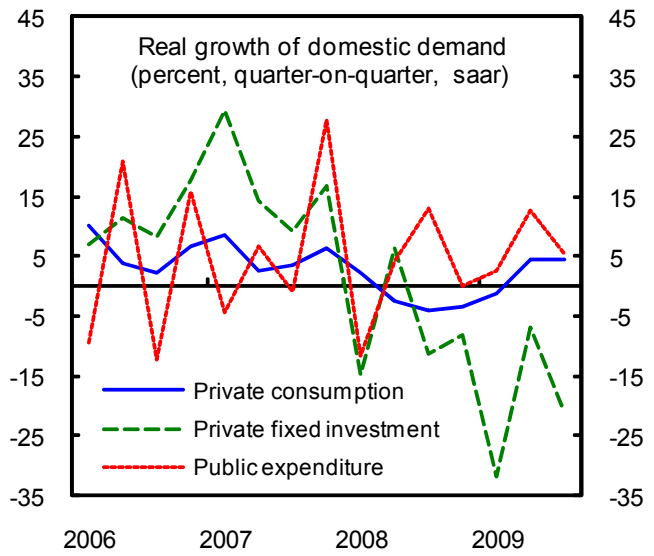

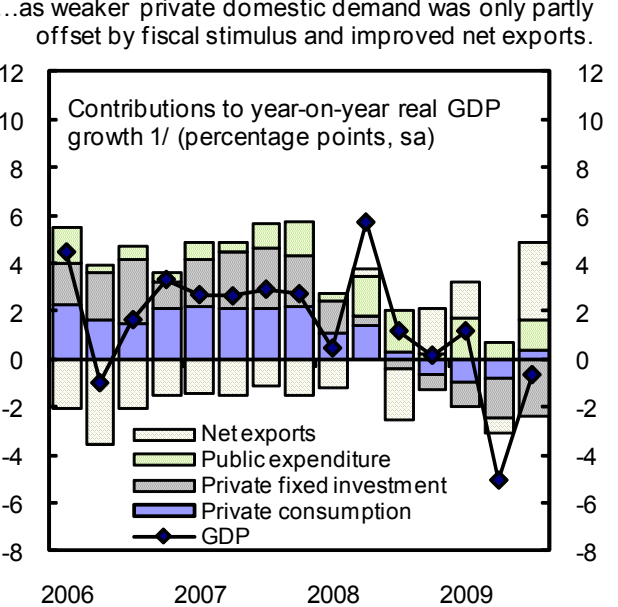

Indeed, rebounding service activity pushed the mainland economy back to growth in

2009Q2..

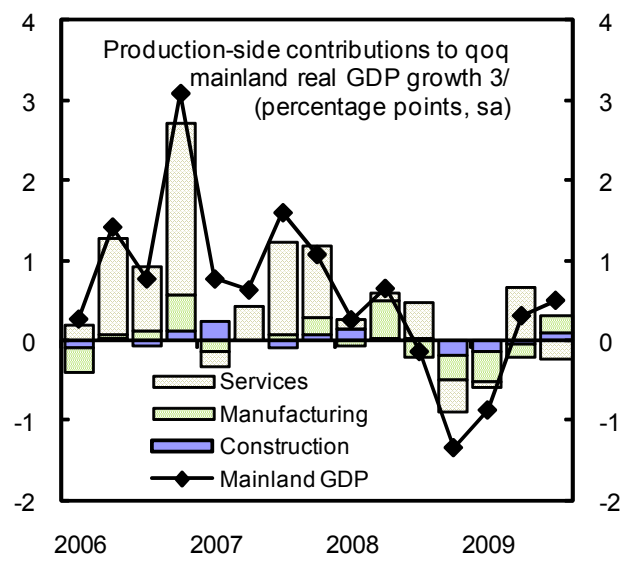

Recent Norwegian recessions have tended to be short and shallow, with the notable exception of the protracted financial crisis during 1988-91.

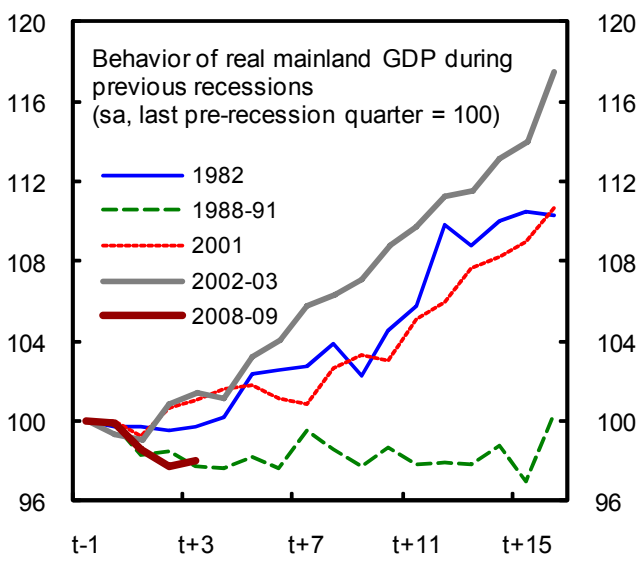

Sources: Statistics Norway, and IMF staff calculations.

1/Difference between GDP growth and sum of components accounted for by inventory investment and statistical discrepancy. 2/Parentheses indicate sectoral share in total value added. Remainder accounted for by agriculture, fishing, mining/quarrying, and utilities.

3/Difference between GDP growth and sum of components accounted for by agriculture, fishing, mining/quarrying, utilities, and taxes minus subsidies. 
Figure 3. Norway: Key Activity Indicators

PMI indicators for manuf acturing have recovered from their 2009Q1 trough, but remain subdued...

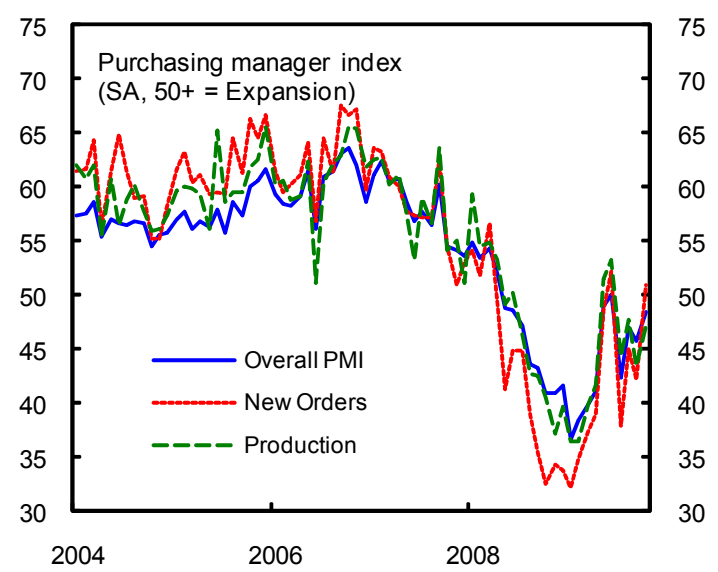

Construction sector activity has also remained weak so far, even as residential house prices have recovered.

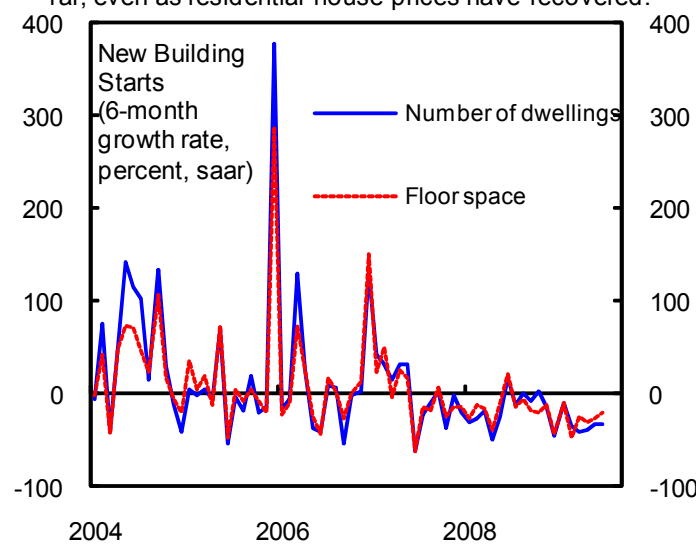

.in sync with a marked improvement in consumer confidence...

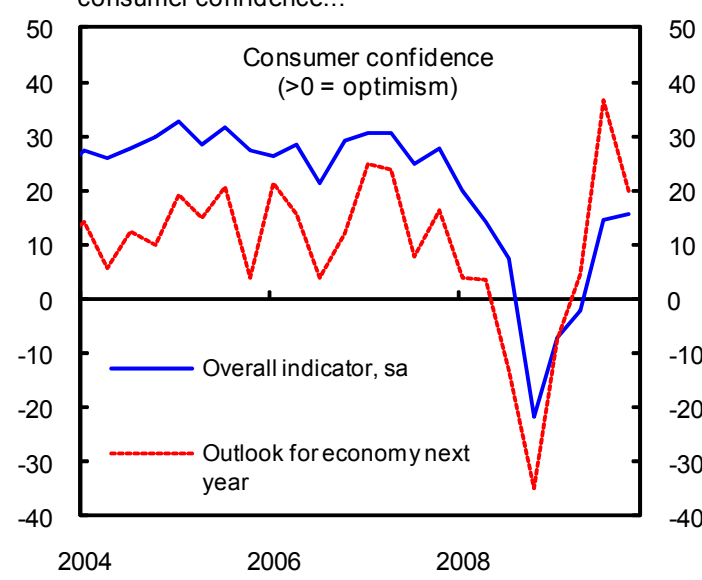

.reflecting a persistently challenging outlook for the industrial sector.

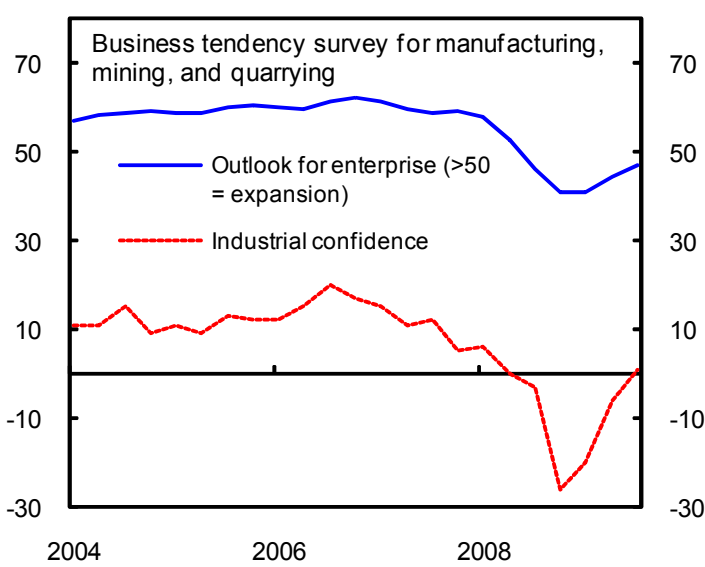

At the same time, retail activity has rebounded

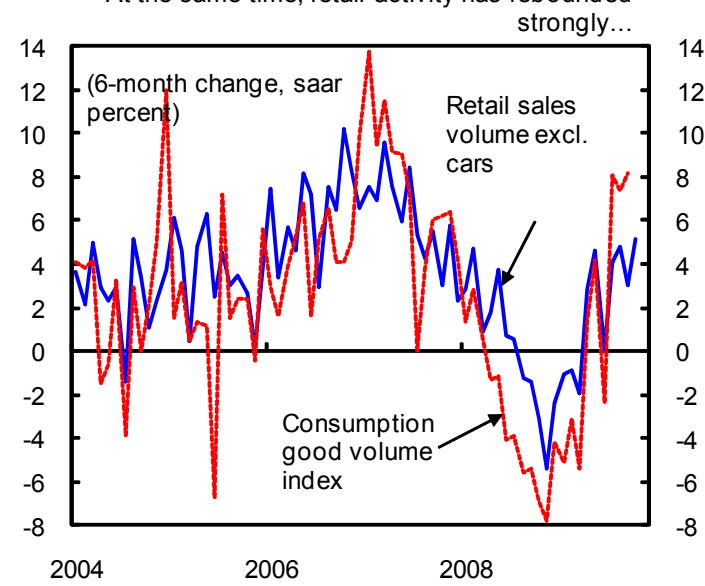

...boding well for a further recovery in consumption.

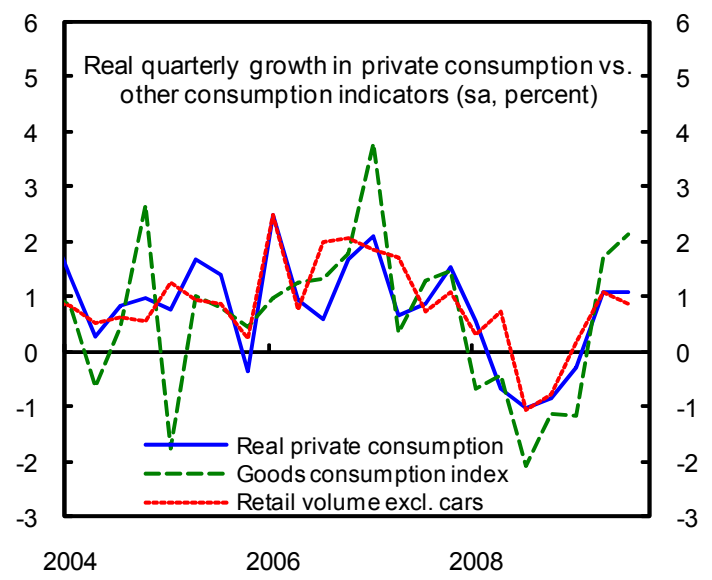

Sources: Haver Analytics, and IMF staff calculations. 
4. The downturn has reduced the pressure on capacity constraints, with some slack emerging in 2009. The authorities responded forcefully to the economic slowdown. They cut interest rates decisively, adopted large fiscal stimulus, and put in place a number of timely measures aimed at shoring up financial intermediation (Annex I). At the same time, the sharp depreciation of the currency in late 2008 supported net exports. Together, these factors have helped keep the recession relatively shallow and short-lived, despite a softening of private consumption and a sharp decline in nonoil private fixed investment. On the production side, construction and manufacturing have contracted significantly and remain subdued, while the decline in service output has been very mild. Unemployment has increased only modestly to about 3 percent and employment has held up, helped by continued net hiring in the public sector. ${ }^{2}$ Still, measures of labor market tightness and capacity utilization suggest that the level of output is now somewhat below potential (Figure 4). Wage pressures have eased, and both headline and core CPI inflation have fallen below the target.

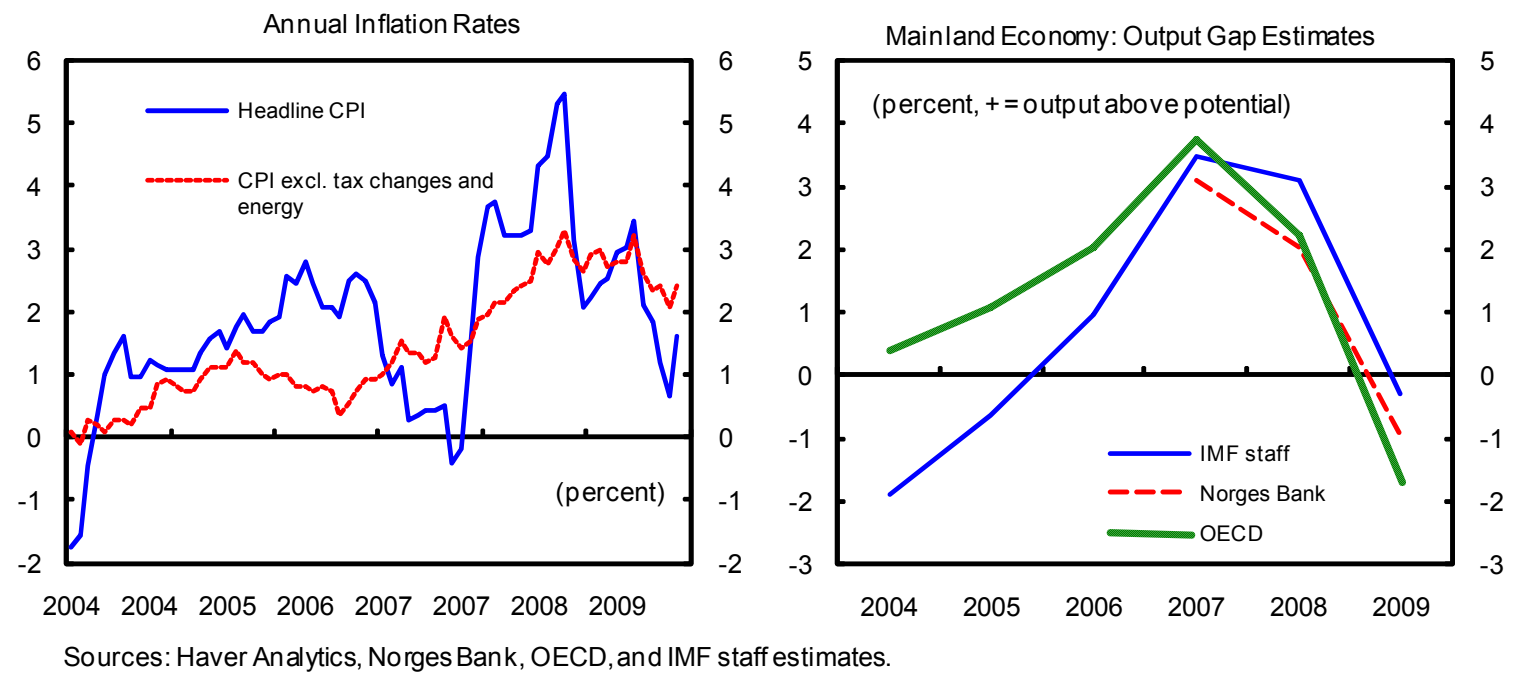

\section{A. Households and Corporations}

5. The private sector is highly indebted. Household debt was close to 200 percent of disposable income at end-2008, one of the highest levels among developed economies. Consumers responded to the combination of falling asset prices and rising uncertainty in late 2008 by raising their saving rates significantly, but improving confidence has recently caused consumption growth to resume. ${ }^{3}$ Corporate debt has also increased rapidly during the boom years (Figure 5 and Table 3 ). In the current environment of low interest rates and continued low unemployment, the debt servicing capacity of households remains relatively strong, but it could deteriorate if downside risks to growth were to materialize or if interest rates rose sharply_more than 90 percent of mortgage loans are at variable rates.

\footnotetext{
${ }^{2}$ The share of public sector employment in total employment is around 30 percent.

${ }^{3}$ The saving rate rose to 8 percent by the third quarter of 2009, from a trough of -1 percent in early 2008 .
} 
Figure 4. Norway: Labor Market

Employment growth has stalled and hours worked have fallen since the beginning of the downturn...

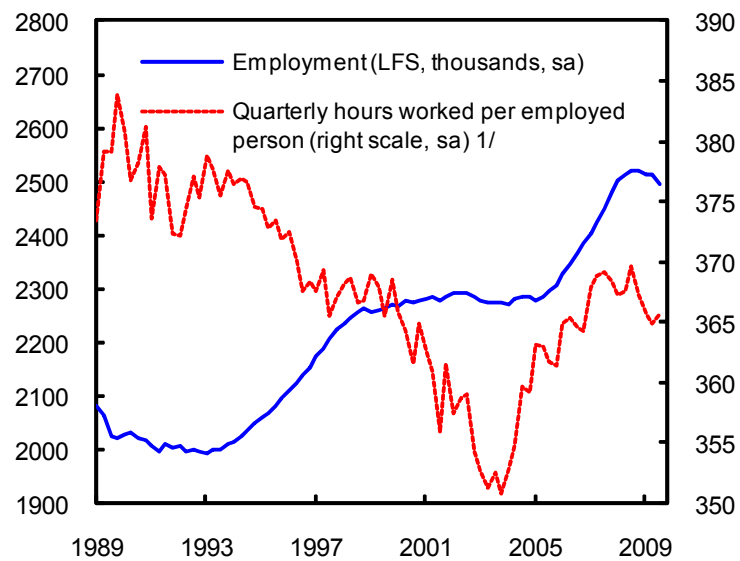

Government demand has provided significant support to employment in recent quarters..

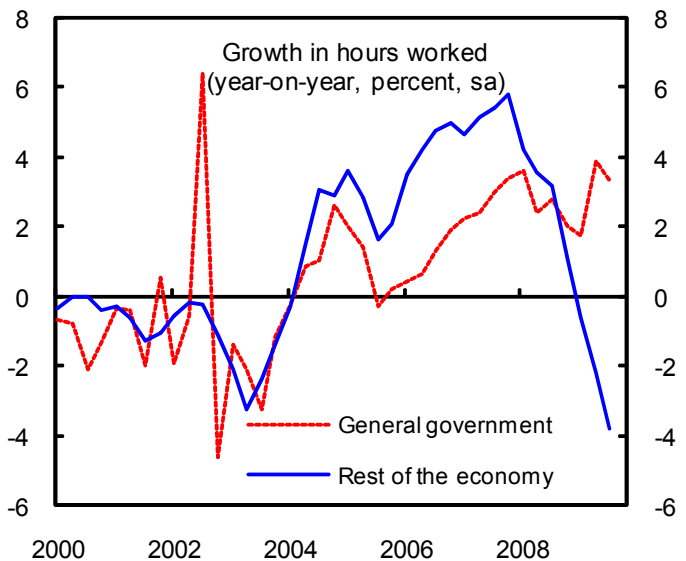

Meanwhile, wage growth has started to ease...

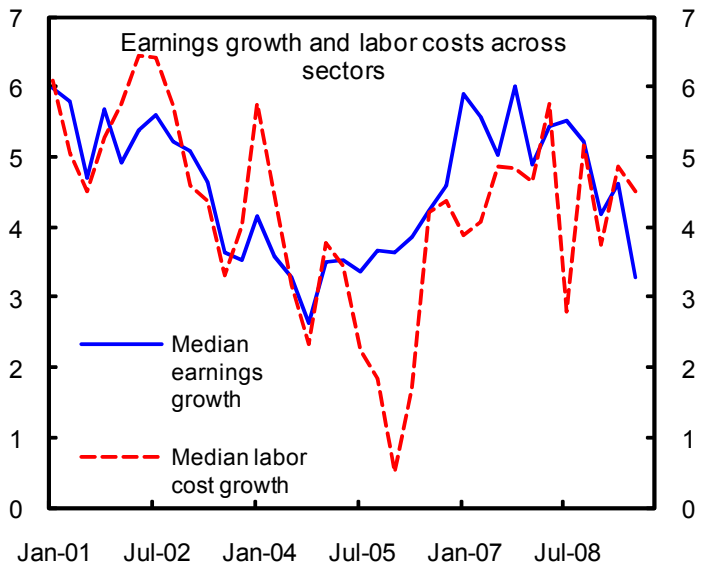

...but unemployment has only risen moderately and remains very low by OECD country standards.

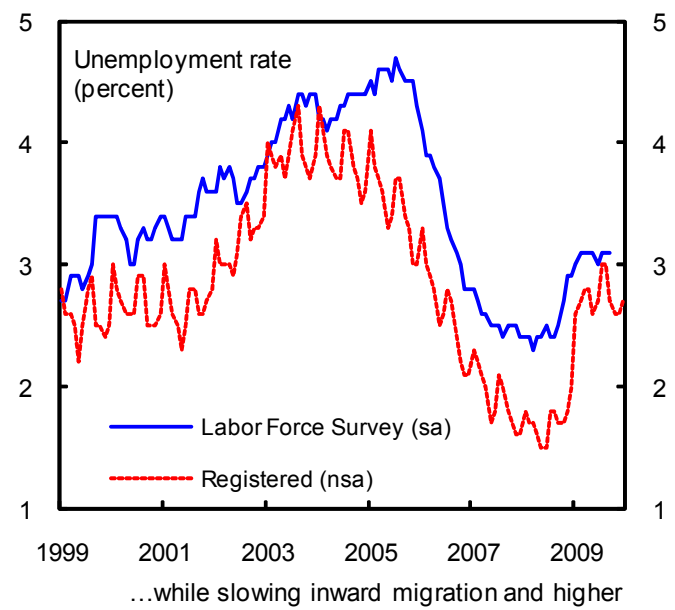
educational enrollment have caused the participation

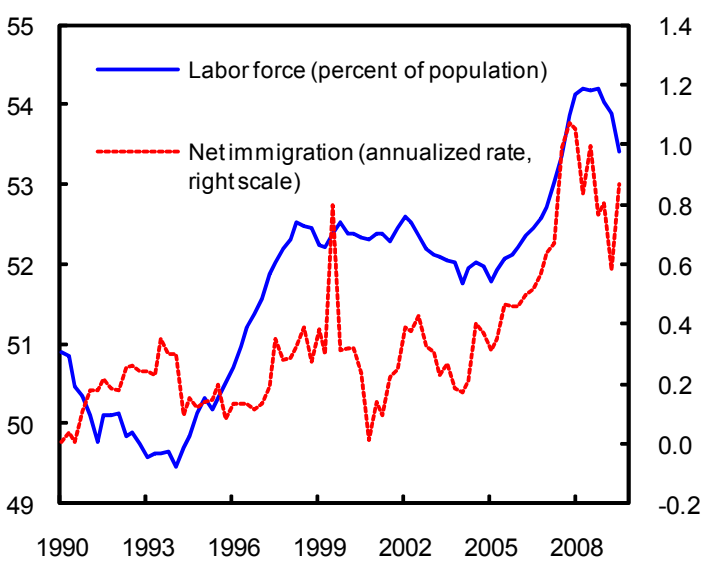

....and bottlenecks have disappeared, although the

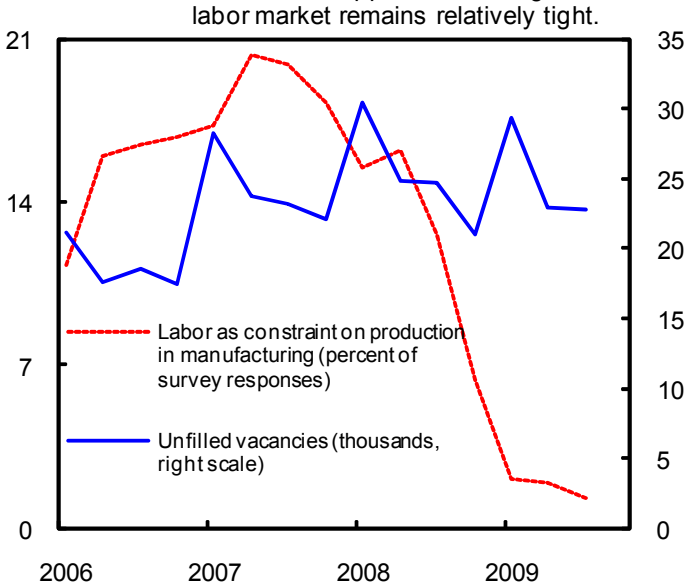

Sources: Haver Analytics, and IMF staff calculations. 
Figure 5. Norway: Household and Corporate Sector

High levels of debt and falling asset prices have weighed on household balance sheets...

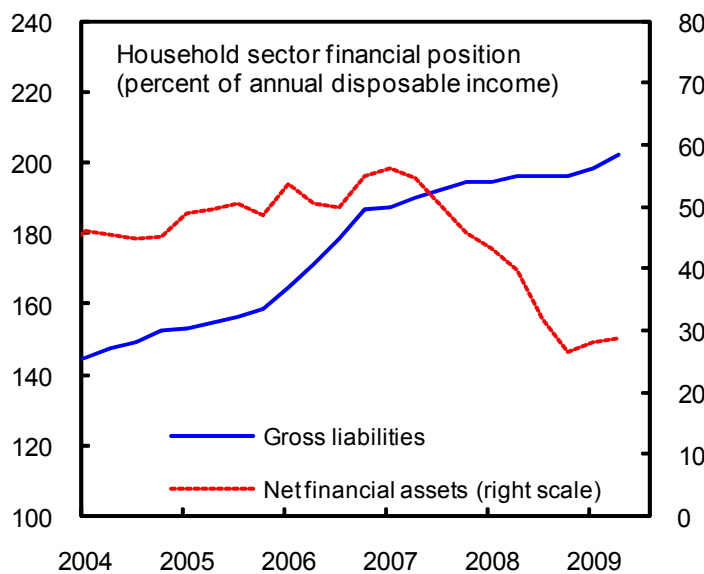

Yet the apparent bottoming-out of house prices, together with continued high employment, should limit further retrenchment of household demand.

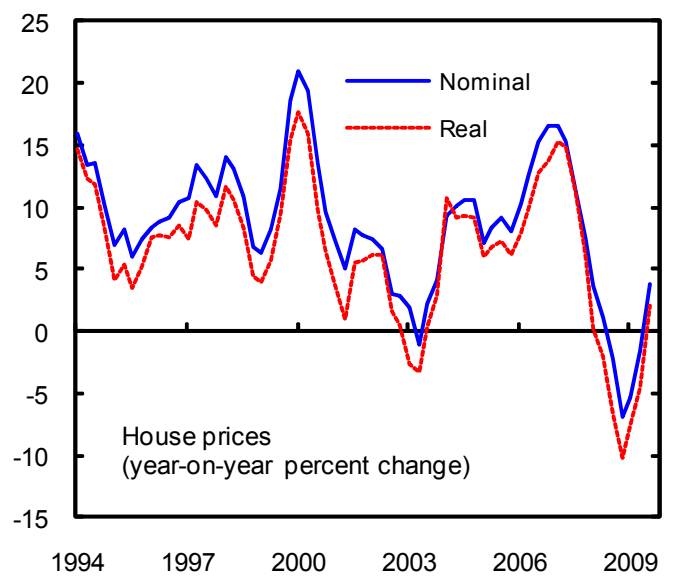

The commercial real estate market has remained weak...

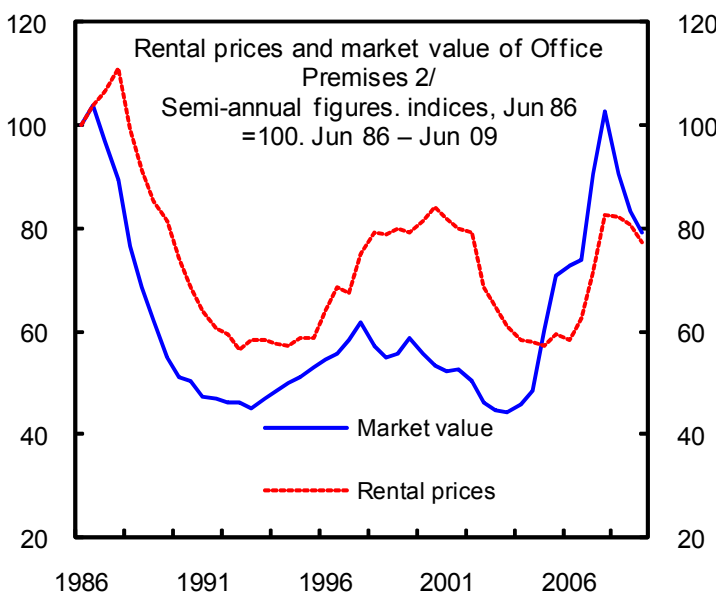

..pushing up the household saving rate.

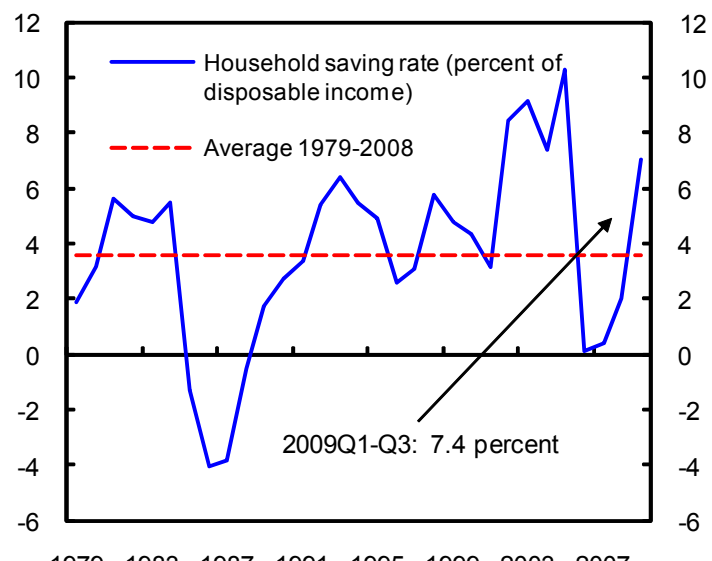

$\begin{array}{llllllll}1979 & 1983 & 1987 & 1991 & 1995 & 1999 & 2003 & 2007\end{array}$

Meanwhile, nonfinancial corporates have started slowing the pace of debt accumulation.

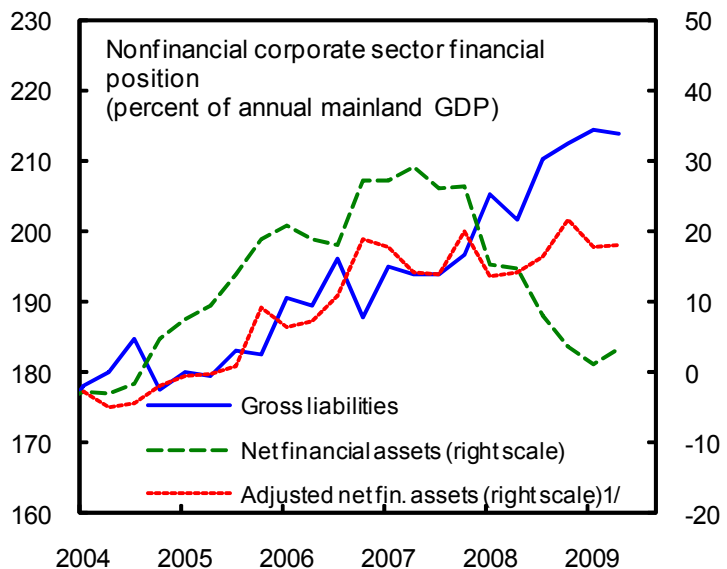

...but corporate bankruptcy rates have increased only moderately from a low base.

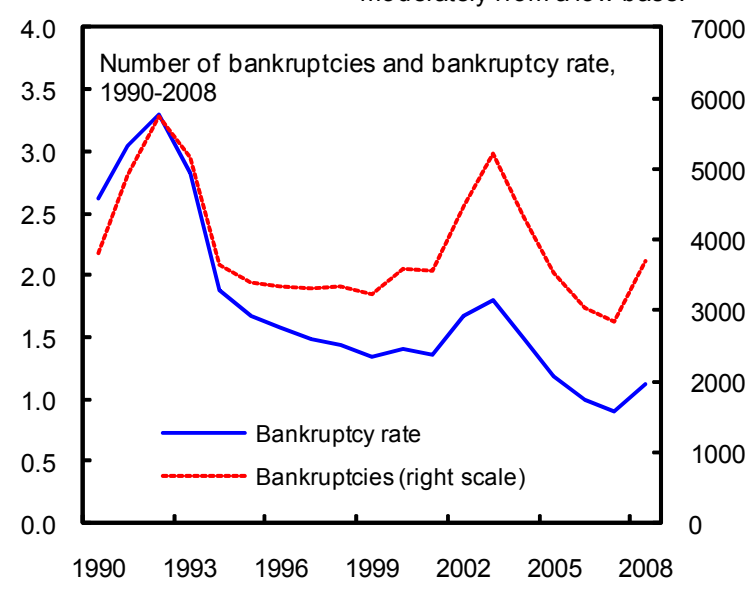

Sources: Haver Analytics, OPAK, Statistics Norway, Norges Bank, and IMF staff calculations.

1/Adjusted so as to reflect only the cumulative effect (since 2004Q1) of transactions in assets and liabilities, thus stripping out valuation effects.

2/High-standard offices centrally located in Oslo. 
6. Residential house prices have recovered after a short-lived correction, but the commercial real estate market remains weak. Prices fell 9 percent below their mid-2007 peak by end-2008, but have rebounded strongly since then. ${ }^{4}$ There is no country-wide index of commercial property prices, but market reports for Oslo suggest that both prices and volumes have fallen in 2008 and remain subdued in 2009. Commercial property accounts for about one third of all corporate loans and the risk on these loans has increased markedly. Since a larger share of commercial property loans are fixed-rate, interest rate reductions have provided less of a respite than in the case of household mortgages.
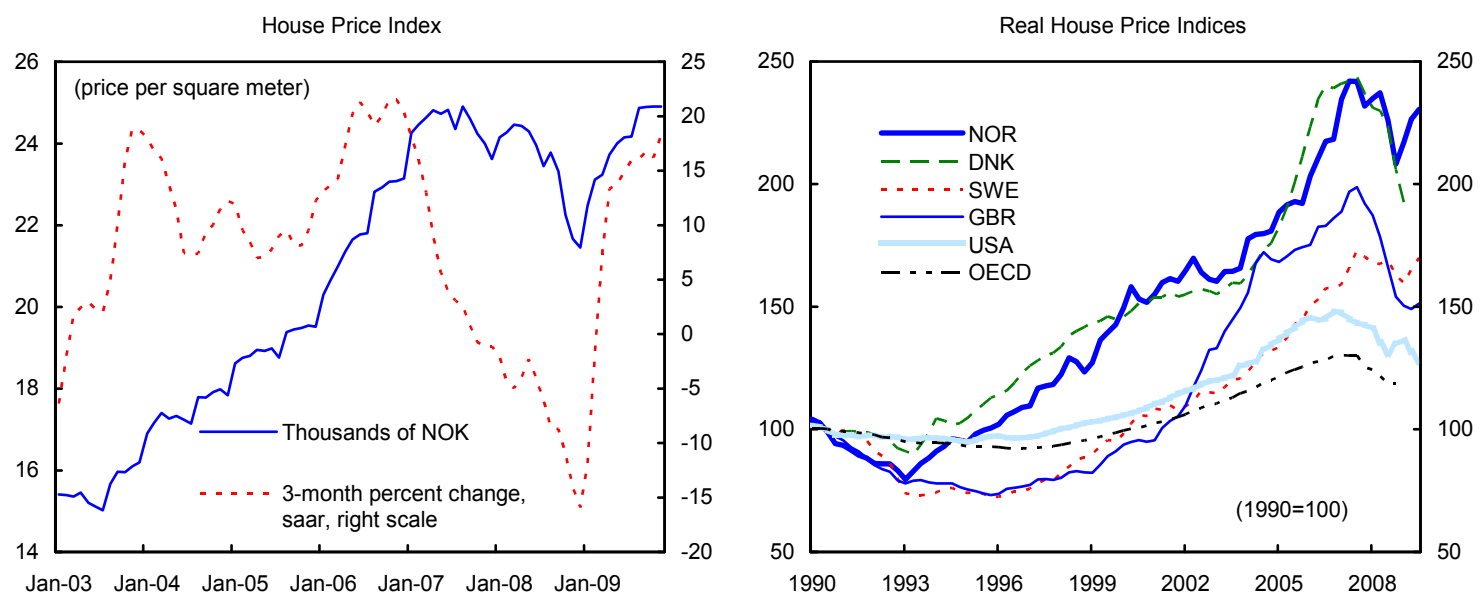

Sources: Norges Eiendomsmeglerforbund (NEF), Eiendomsmeglerforetakenes Forening (EFF), Haver Analytics, OECD, and IMF staff calculations.

\section{B. Financial Institutions}

7. Wide-ranging policy actions have helped contain the effect of the crisis on the domestic financial system. Domestic financial institutions experienced a severe liquidity shortage, although there were no solvency issues. Norway's banks rely on US dollar interbank markets - they fund themselves through a combination of dollar loans and crosscurrency swaps. With the drying up of these markets in the wake of Lehman's bankruptcy, the availability of term funding diminished sharply and spreads surged. The domestic corporate bond market also became highly illiquid. To ease liquidity conditions, the authorities introduced a number of measures, including extended maturities and relaxed collateral requirements for Norges Bank loans, a swap program to provide banks with government securities in exchange for covered bonds, and direct provision of foreigncurrency loans. A Government Bond Fund has been set up to support liquidity and pricing in the corporate bond market. These measures - along with similar steps undertaken in other economies - have helped stabilize financial markets. Interbank lending spreads have come down, and demand for bonds has returned.

\footnotetext{
${ }^{4}$ Based on the methodology used in the April 2008 World Economic Outlook, Norway's house prices appeared to be 5 to 10 percent overvalued in mid-2009.
} 
8. Financial institutions have also benefited from a stable domestic economy, low exposure to toxic assets, and a relatively conservative regulatory regime. The strong macroeconomic stimulus has mitigated the economic downturn and supported borrowers' ability to service their debt. In addition, Norwegian financial institutions had negligible exposure to U.S. subprime mortgages and structured credit products and overall bank leverage is relatively low (Figure 6). Reflecting the legacy of the early 1990s banking crisis (Annex II), the regulatory regime in Norway is rather conservative in several aspects. For example, securitization is essentially limited to covered bonds; and investment banks are subject to similar standards of supervision and capital requirements as commercial banks. These factors have underpinned the relative resilience of domestic

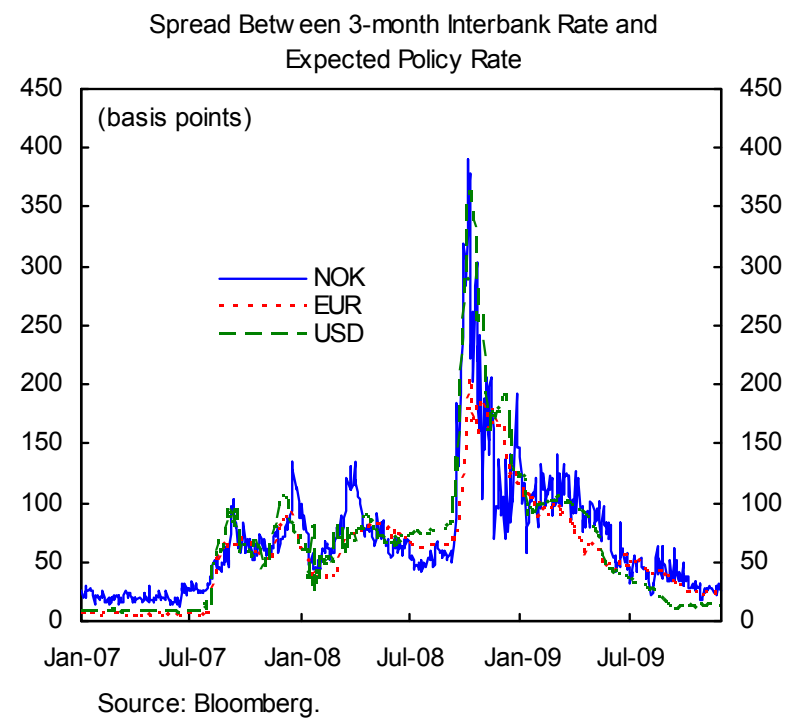
financial institutions.

9. Looking ahead, a cyclical deterioration of credit quality remains a concern. The banking system has large exposure to cyclically-sensitive sectors such as shipping and commercial property. In addition, some of Norway's largest resident banks have operations in recession-hit neighboring economies, although the exposures are relatively small (Box 1). Nonperforming loans have increased only modestly so far (from about $1 / 2$ percent prior to the crisis to just above 1 percent of all loans in the third quarter of 2009), but could rise further as the shipping industry faces significant global excess capacity and commercial real estate markets remain subdued (Figure 7 and Table 4). In addition, households' high indebtedness, combined with a richly valued housing market, makes bank portfolios vulnerable to adverse economic shocks.
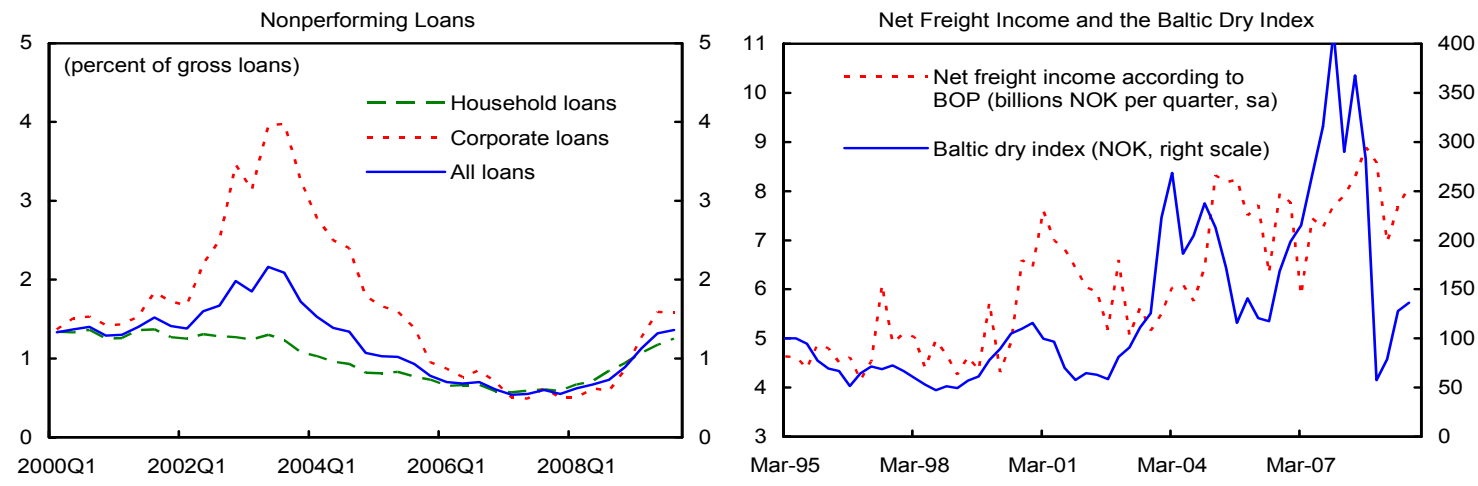

Sources: Bloomberg, Haver Analytics, Norges Bank, Statistics Norway, and IMF staff calculations.

5 These risks triggered Moody's downgrading of several Nordic banks, including DnB NOR, in mid-2009. 
Figure 6. Nordic Banks' Relative Performance: 2003-08
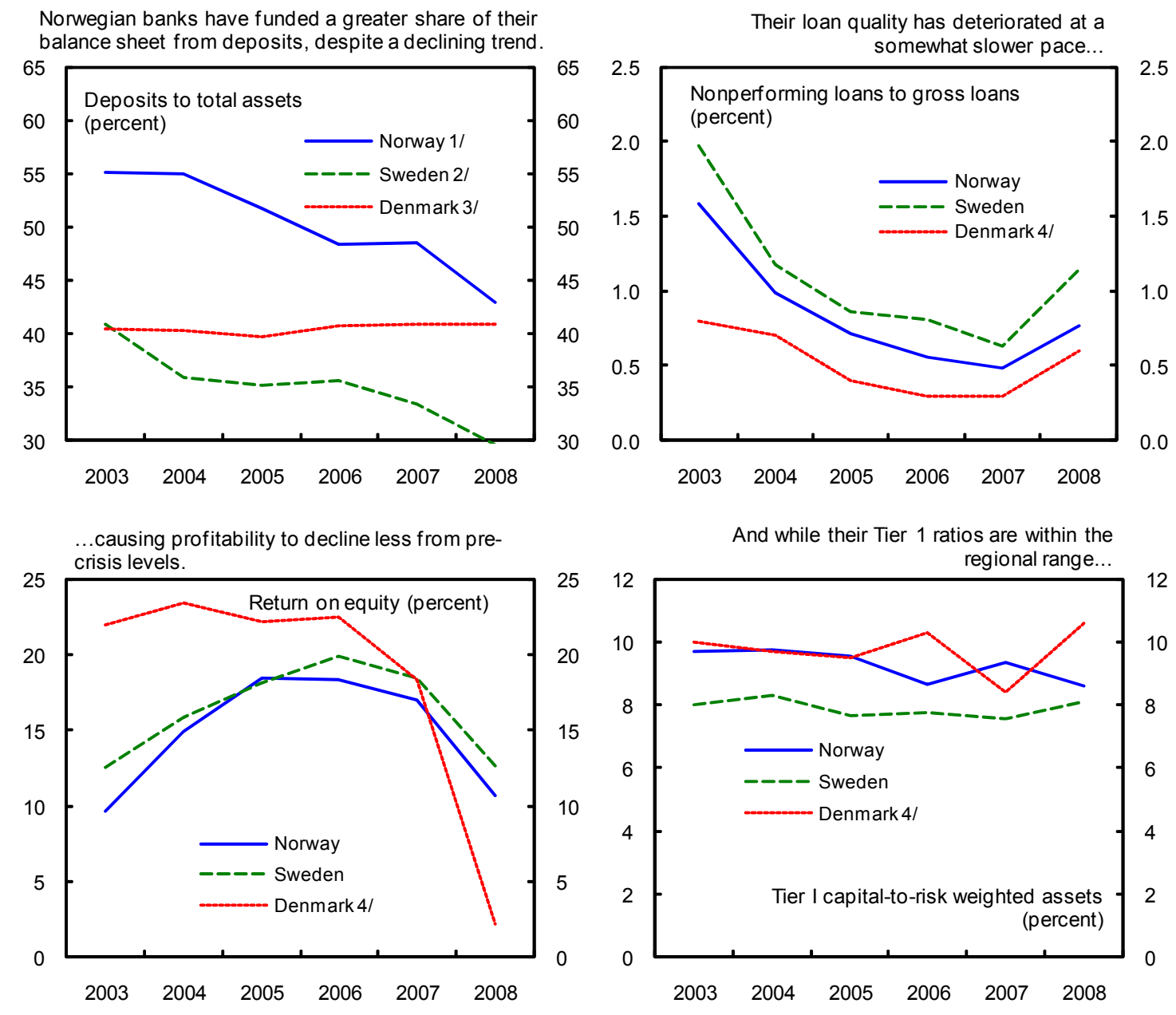

...overall leverage remains somewhat lower in Norway...
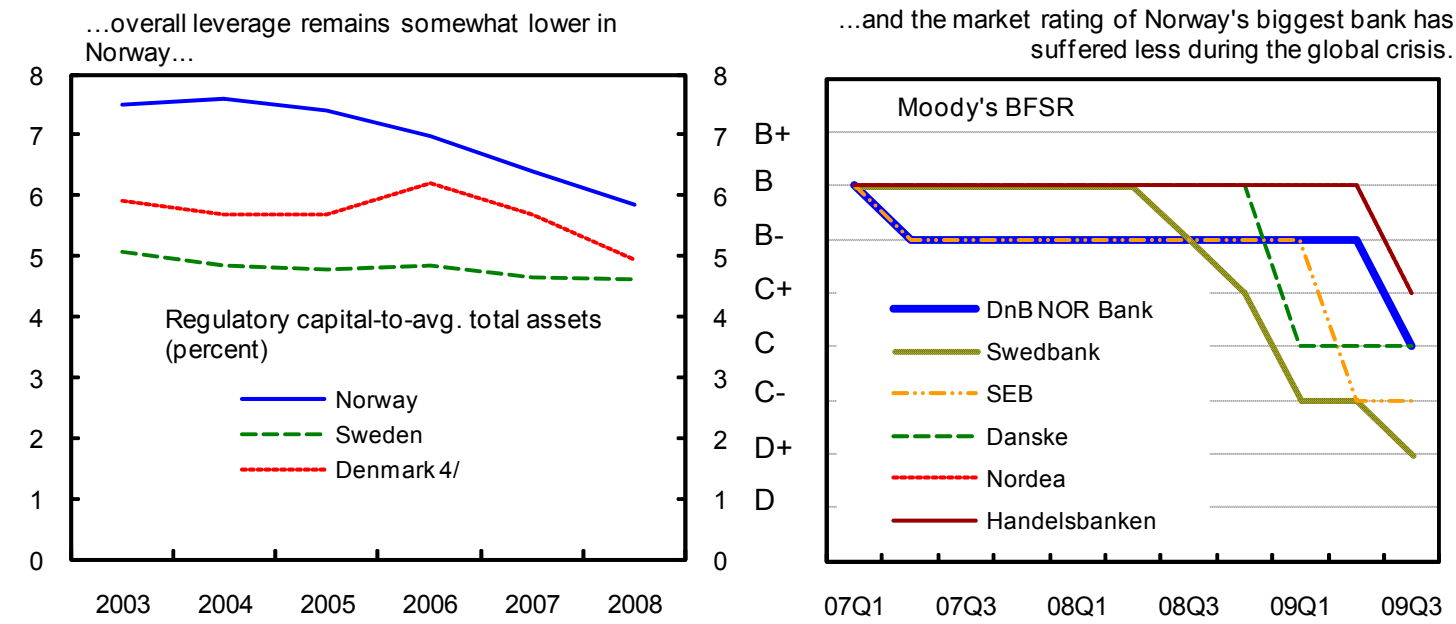

Sources: Norges Bank, Swedish Financial Supervisory Authotity, Riksbank, Danish Financial Supervisory Authority, Danmarks Nationalbank, and IMF staff calculations.

Coverage: All domestic credit institutions and foreign owned branches and subsidiaries in Denmark, Sweden,

and Norway.

$1 /$ Norway $=$ Customer deposits to non-interbank lending * loans-to-assets.

$2 /$ Sweden $=$ Total deposits of the general public (banks) $/$ Total assets (banks)

$3 /$ Denmark $=$ Total deposits (all MFIs) $/$ Total assets (all MFIs).

4/Capital-to-assets and nonperforming loan data for all banks for 2003-07; other information for Group I Banks. 


\section{Box 1. Structure and Cross-Border Linkages of the Norwegian Banking System}

The global financial crisis has highlighted vulnerabilities related to cross-border banking activity. Norway's banking system is integrated into the broader Nordic market, but cross-border exposures remain limited compared to other advanced countries. A key risk is the banks' reliance on foreign wholesale funding, which caused a liquidity squeeze at the peak of the post-Lehman turmoil.

Banks and mortgage credit institutions (MCIs) dominate Norway's financial landscape, accounting for nearly 80 percent of total sector assets at end-September 2009 (Table 5). Partly government-owned DnB NOR is by far the largest player, controlling almost 38 percent of overall bank/MCI assets. The remainder of the sector consists of a few mid-sized banks and a large number of small (savings) banks.

Despite significant regional linkages, Norway's banking system features limited cross-border exposure by international comparison:

- About one-third of the domestic banking system is foreign-owned. This includes a few relatively large lenders with parents from other Nordic countries. Some of these entities operate through branches, heightening the risk of spillovers from foreign markets in which the parent companies conduct business. Indeed, there is anecdotal evidence of some credit retrenchment by foreign-owned branches at the height of the global crisis. ${ }^{1}$

- Among the Norwegian-owned banks, only DnB NOR has nonnegligible foreign operations. Some 25 percent of DnB NOR's total lending is outside of Norway, again mostly in the Nordic region. Around one-fifth of this exposure relates to a Danish subsidiary with operations in the Baltic countries, including crisis-hit Latvia. Despite significant loss rates from these operations, DnB NOR's overall exposure appears limited (text table). More generally, the external claims of the consolidated Norwegian banking system are rather small by international comparison.

\begin{tabular}{|c|c|c|c|c|c|}
\hline Swedbank & SEB & DnB NOR & Nordea & Danske & SHB \\
\hline \multicolumn{6}{|c|}{ (in percent of gross loans at the group level) } \\
\hline 16.9 & 15.0 & 3.5 & 2.9 & 1.7 & 0.1 \\
\hline
\end{tabular}

- Dependence on foreign funding markets represents the Achilles' heel of Norway's banking system. Norwegian banks rely extensively on short-term funding from abroad. As a result, some banks faced a significant liquidity squeeze when these markets seized up in the wake of the Lehman bankruptcy. The Norwegian authorities responded by providing extensive liquidity in domestic and foreign currency, and creating a covered bond swap program. Nonetheless, dependence on foreign wholesale markets remains a structural vulnerability.

${ }^{1}$ The Icelandic bank Kaupthing also had a small branch in Norway. It was successfully unwound-not causing any losses to domestic creditors - in late 2008. 
Figure 7. Norway: Bank Performance
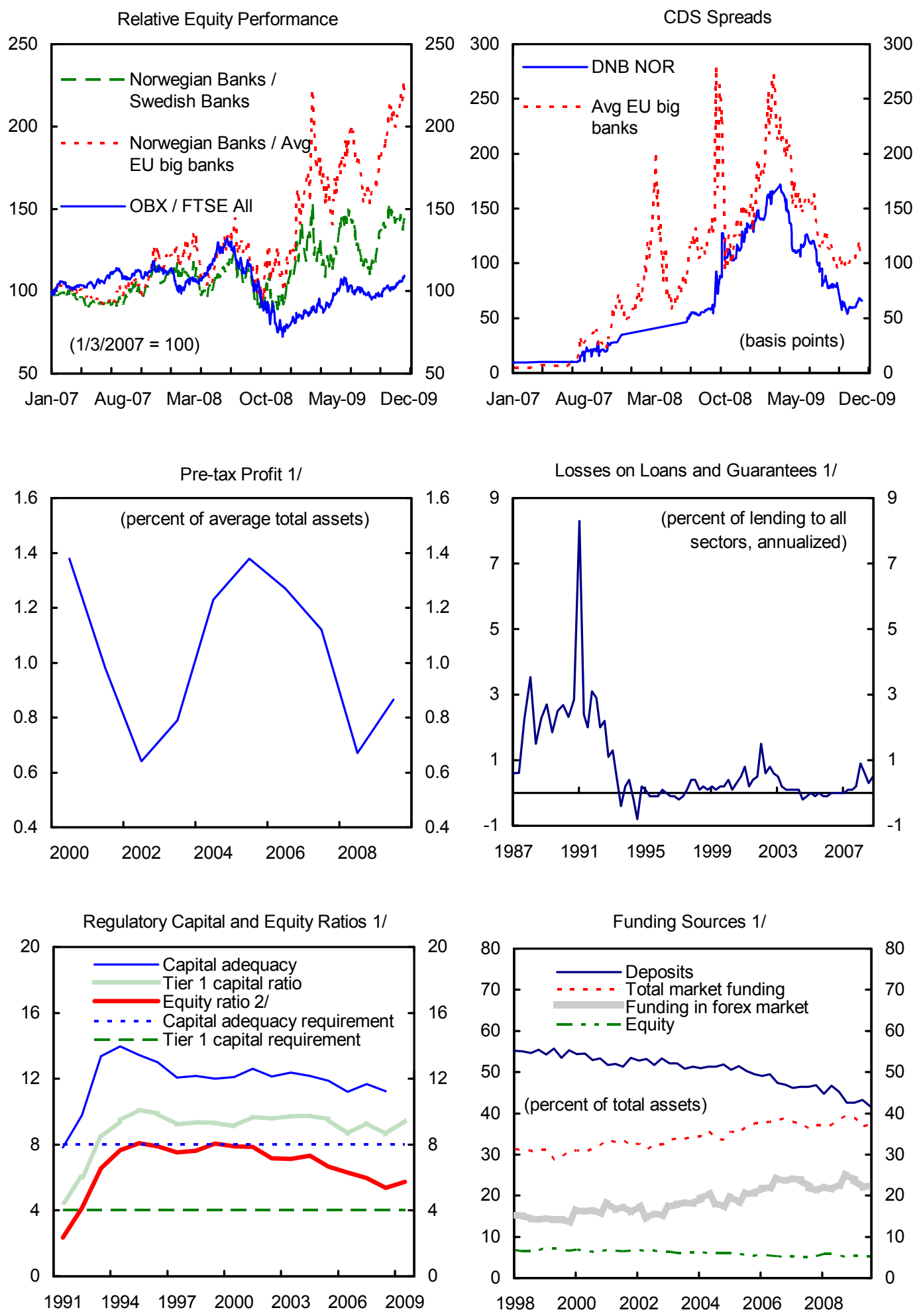

Sources: Bloomberg, Norges Bank.

1/ All banks except branches of foreign banks in Norway. 2009 data through end-September only.

2/ Shareholder equity (including retained earnings)/ total assets. 


\section{Credit Developments}

10. Credit standards have started to ease, although the growth of banks' corporate lending remains subdued (Figures 8 and 9). Norges Bank's survey of bank lending shows that credit standards for both households and corporations started to ease in the second half of 2009 after tightening considerably during the global crisis. The growth of credit to the corporate sector has declined sharply, partly due to weaker demand. Meanwhile, household credit growth has moderated, but remains robust at an annual rate of nearly 7 percent. Looking ahead, banks envisage no further tightening of credit standards and expect some increase in loan demand. Lending rates have fallen broadly in line with the reduction of the policy rate. Corporate bond issuance has strengthened in 2009, boosted by government support measures and returning risk appetite.

\section{Public Sector}

11. Fiscal policy was relatively restrained during 2006-07, but turned very expansionary with the onset of the global crisis. The government maintained a broadly neutral fiscal stance during the period of high economic growth in the first half of its previous four-year term. This relative fiscal restraint, along with rapid asset accumulation in the nation's wealth fund, helped reduce the structural nonoil deficit slightly below 4 percent of wealth fund capital (the benchmark under Norway's fiscal guidelines). Policy rapidly shifted to an expansionary stance as the global crisis set in, with discretionary stimulus close to 3 percent of mainland GDP in 2009. Despite the simultaneous drop in hydrocarbon and cyclical tax revenue, Norway continues to post a significant overall fiscal surplus (Tables 6 and 7).

\section{E. External Position}

\section{Norway's external}

position is strong. The overall current account remains in large surplus, although it narrowed in 2009, mainly reflecting lower prices and volumes of hydrocarbon exports (Table 8 and Figure 10). In recent years, a number of Norway's key manufacturing and food exports have gained market share, indicating continued strong international competitiveness. Norway's net foreign assets have continued to grow in 2008, supported by large inflows into the sovereign wealth fund.

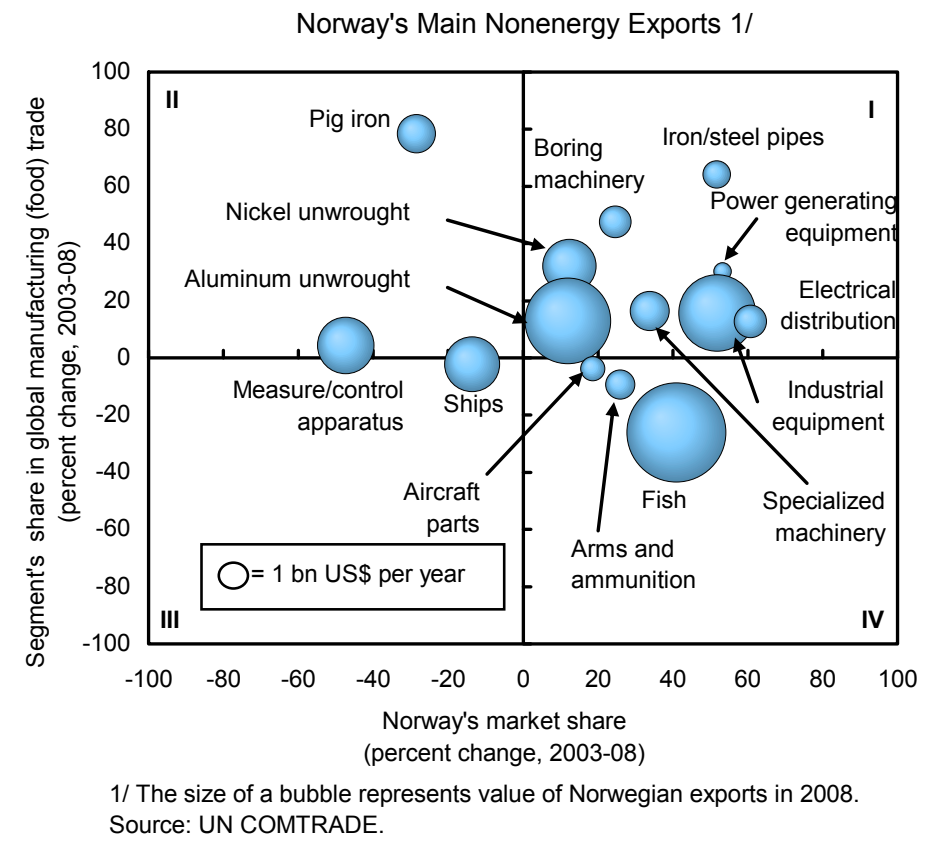


Figure 8. Norway: Credit Market Developments
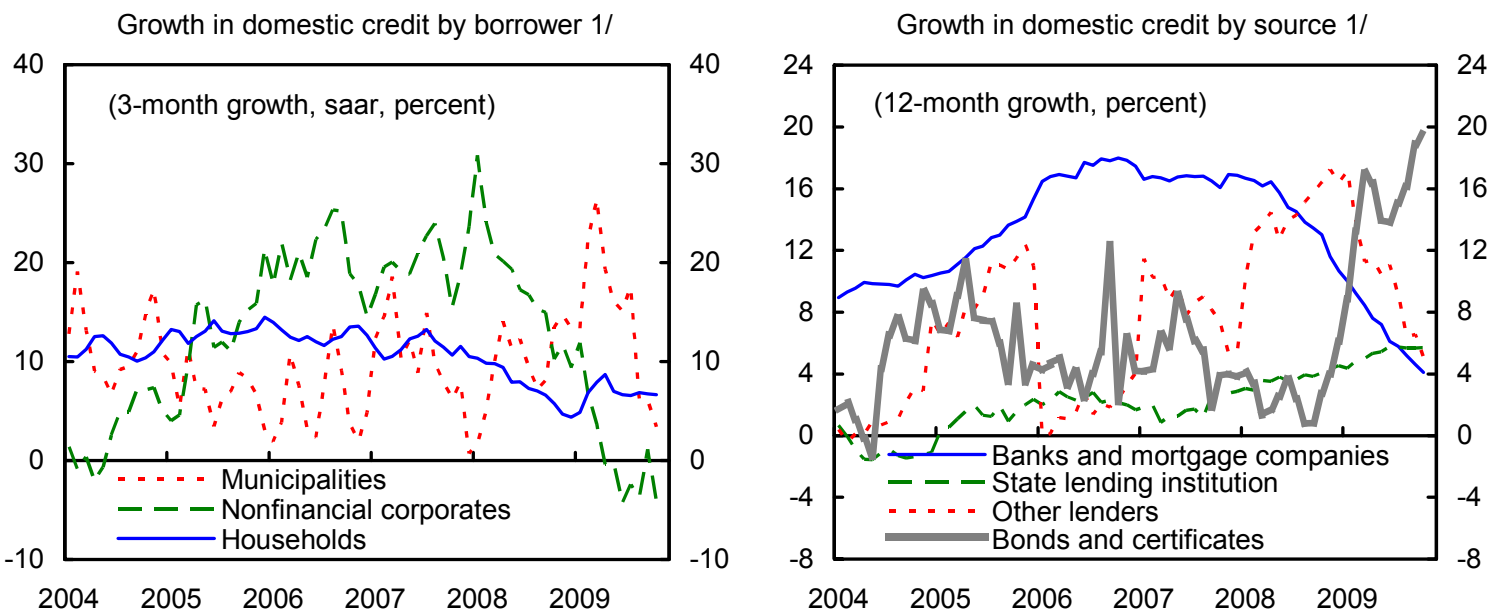

Contribution to Annual Growth in Domestic

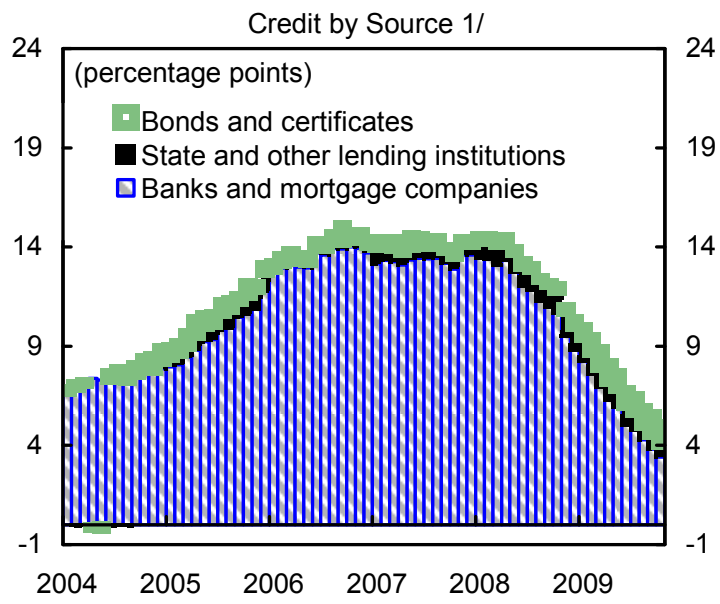

Composition of Domestic Credit by Source

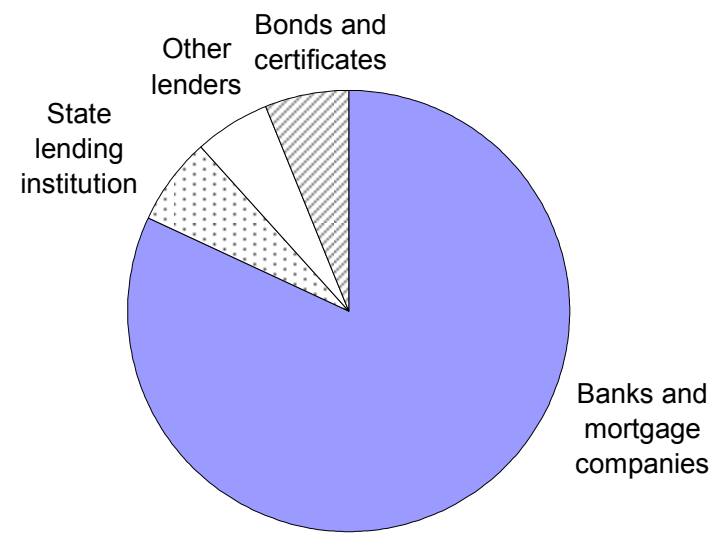

Sources: Statistics Norway, and IMF staff calculations.

1/ Contains FX-denominated debt, as well. Growth rate adjusted for exchange rate movements. 
Figure 9. Norway: Credit Standards and Lending Rates

Credit standards for corporate borrowers have started to ease again..
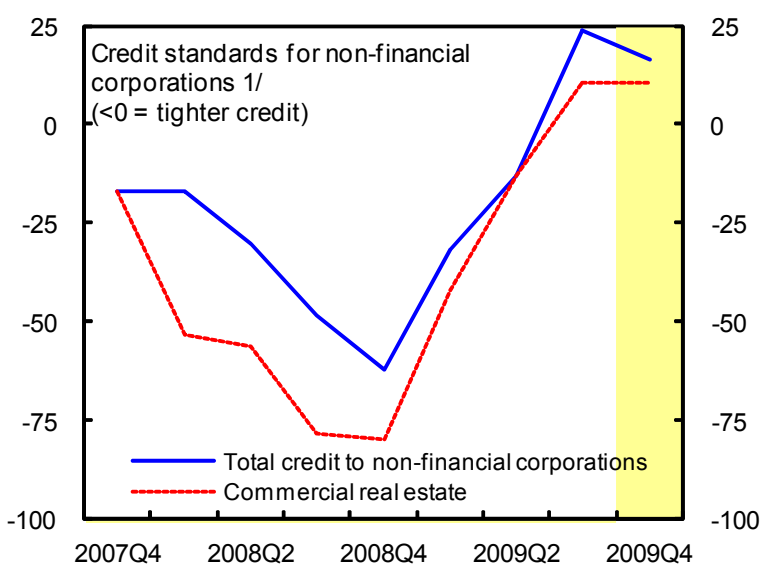

Demand for corporate lending is expected to resume..

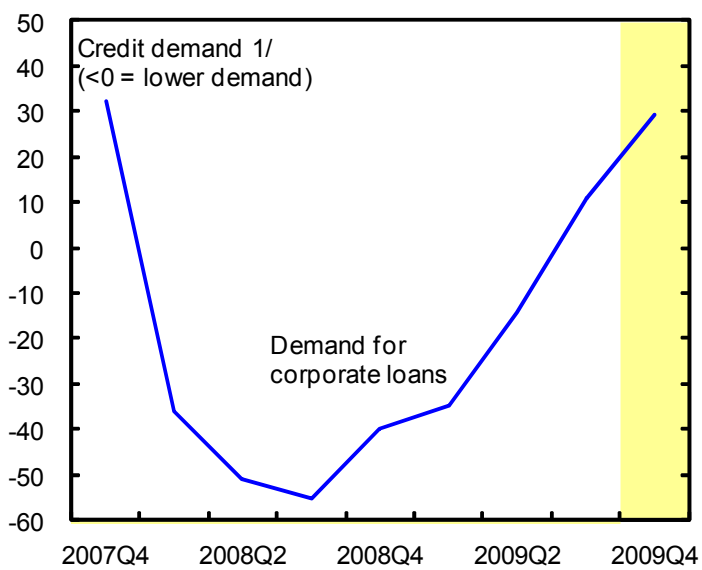

Household credit demand has stabilized, and lending standards have stopped tightening...

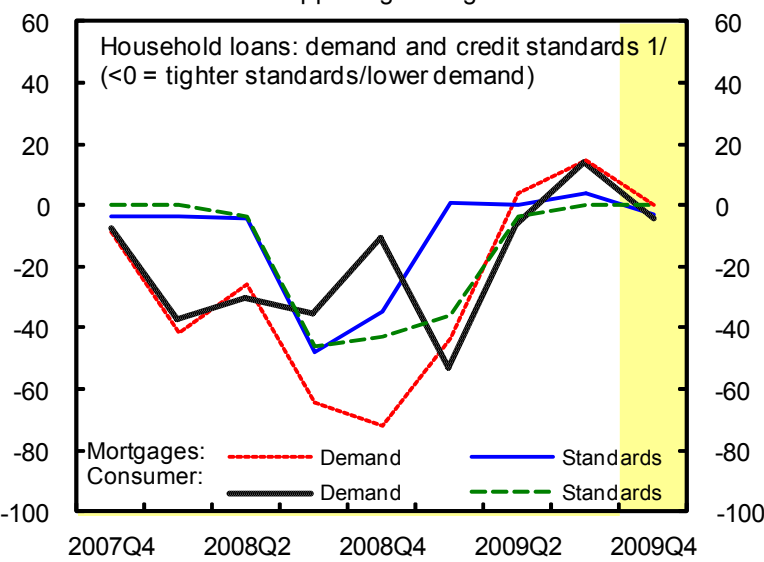

..while sizable policy rate cuts led to lower lending rates for nonfinancial corporations.

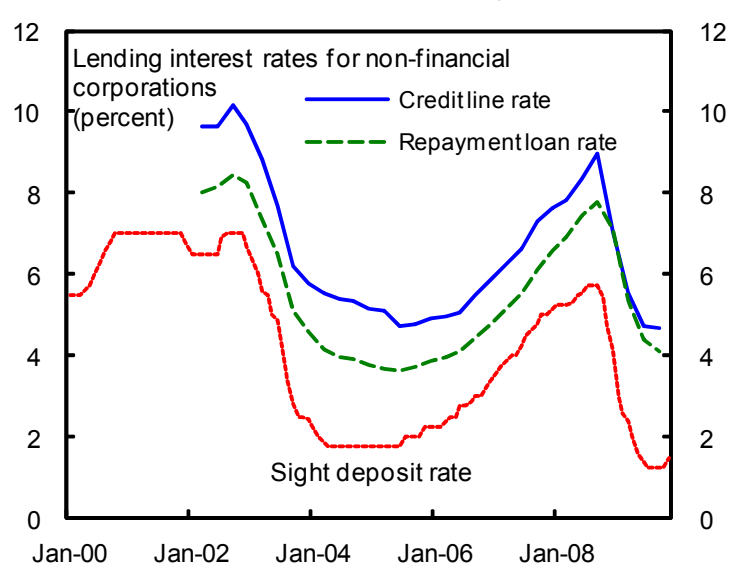

while credit line drawings should stabilize.

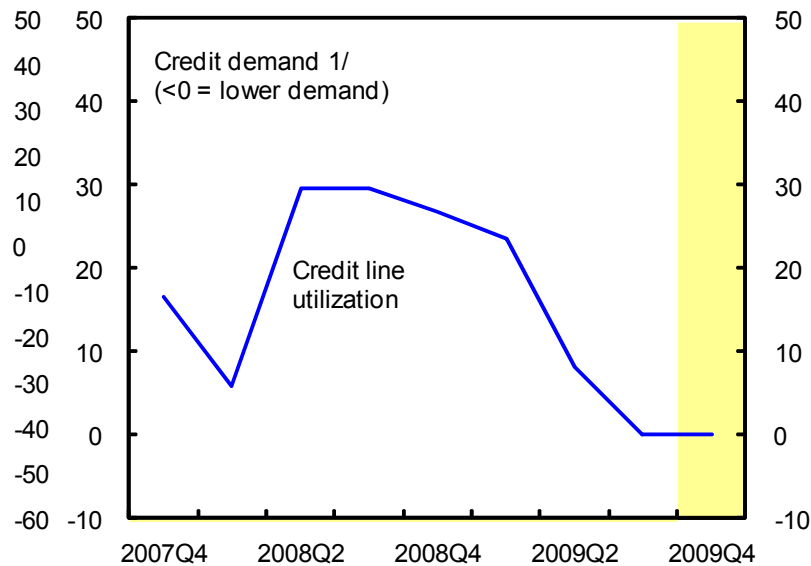

..while interest rates on loans to households have fallen sharply.

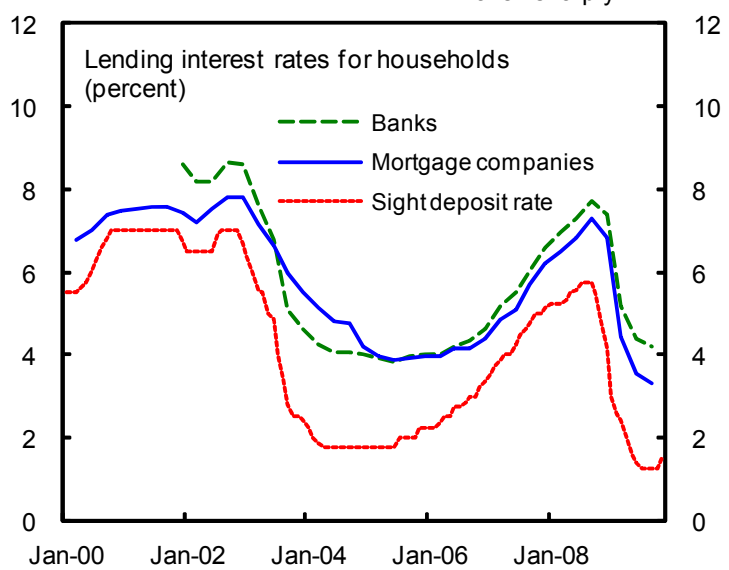

Sources: Haver Analytics, Norges Bank, and IMF staff calculations.

1/Latest shown observations correspond to the expectations for the third quarter of 2009 from the Norges Bank's Survey of Bank Lending conducted in the period 1 July $2009-10$ July 2009. 
Figure 10. External Developments

The krone has strengthened again after a sharp depreciation at the end of 2008

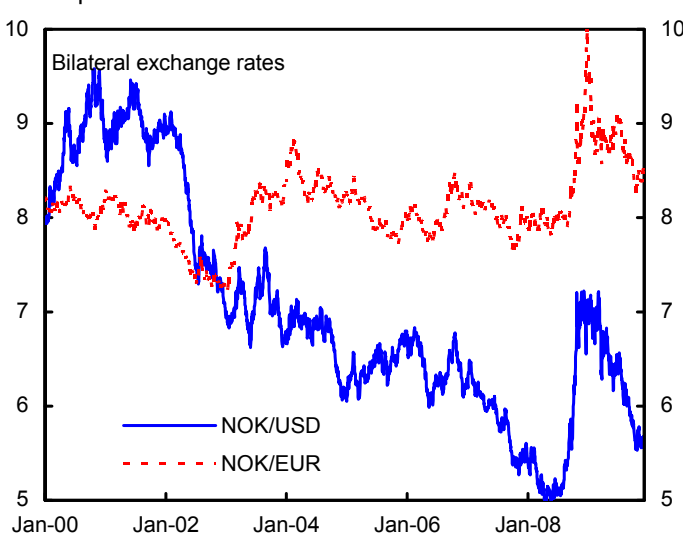

The current account surplus has narrowed somewhat...

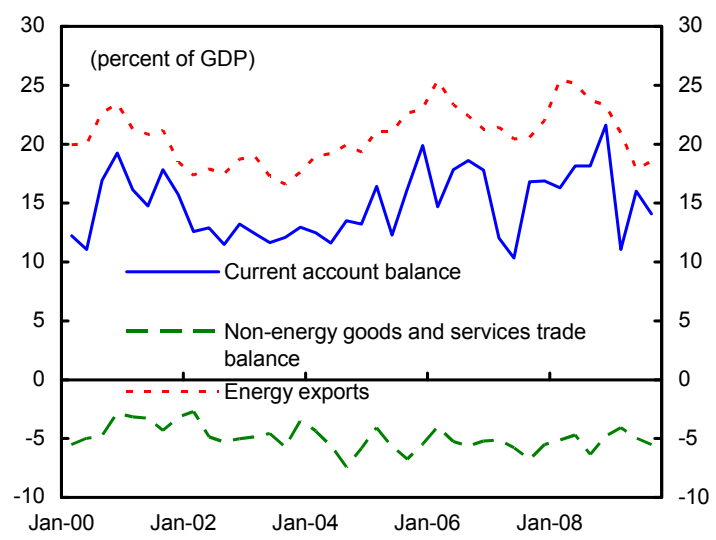

Still, Norway has experienced a less pronounced decline in exports than some of its neighbors...

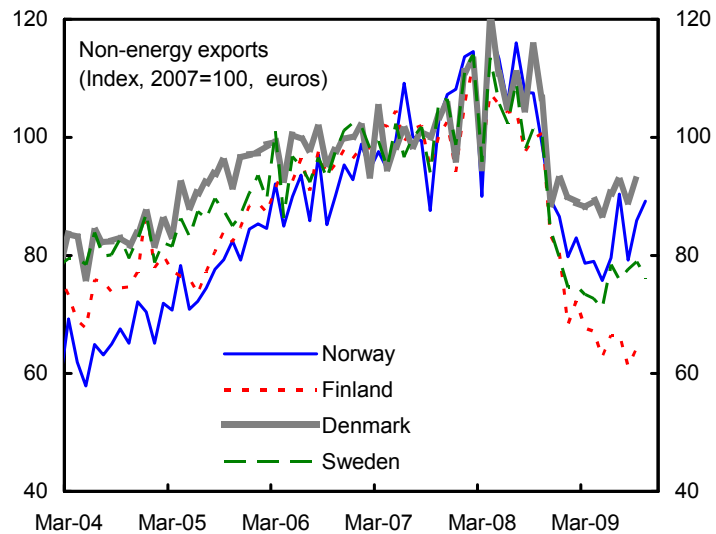

Despite this volatility, the real effective exchange rate is now close to its 10 -year average.

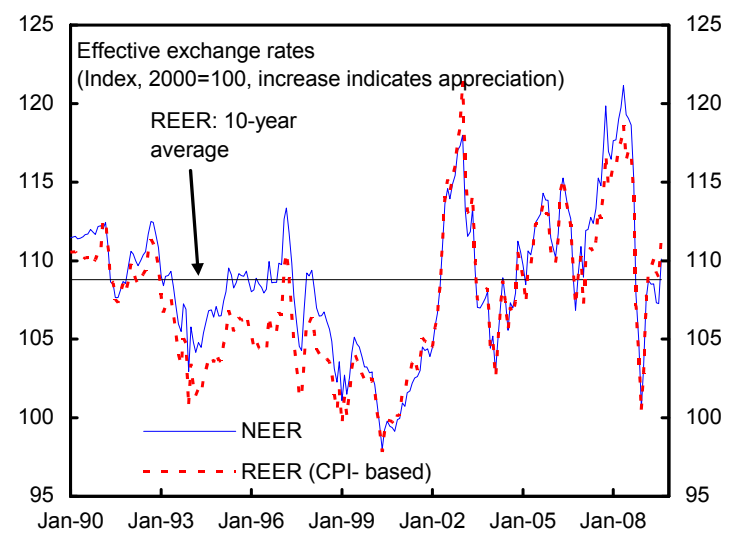

as energy exports have weakened.

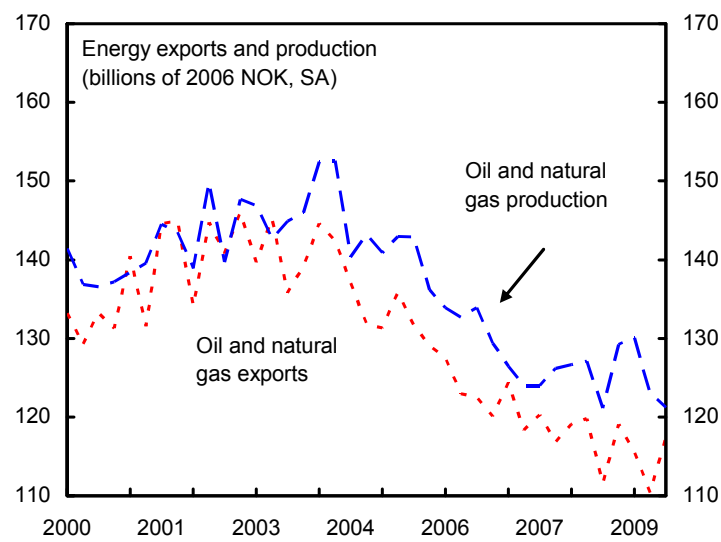

...which is partly explained by a lower share of manufacturing and a higher share of food-related

exports.

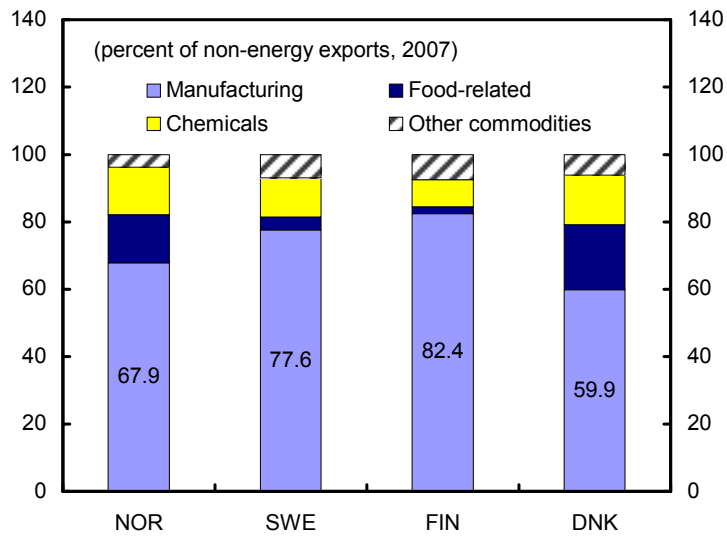

Sources: Bloomberg, Haver Analytics, IMF Information Notice System, and IMF staff calculations. 
13. The value of the krone appears to be broadly in line with fundamentals. The nominal exchange rate depreciated sharply in late 2008 as oil prices dropped and foreign investors sold Norwegian assets in the post-Lehman flight to liquidity. However, the krone has steadily appreciated in the course of 2009, recouping most of the earlier losses. Equilibrium estimates based on CGER methodologies, adjusted for the fact that Norway is an oil and gas exporter, suggest that the krone is now close to equilibrium (Box 2). The CPI-based real effective exchange rate was also close to its long-term average in the third quarter of 2009. The manufacturing ULC-based real effective exchange rate has appreciated more strongly in recent years, reflecting high domestic wage growth. Given very favorable terms-of-trade developments, the resulting cost pressures appear not to have undermined export performance so far. However, continued high wage growth could cause strains in some export-oriented sectors going forward, especially if the terms of trade were to turn around.

\section{F. Outlook and Risks}

14. The economic recovery is expected to continue, with private domestic demand progressively replacing public spending as the main driver of growth. Staff projects mainland growth at $2 \frac{1}{4}$ percent for 2010 , broadly in line with the authorities' and private analysts' forecasts. Private consumption is expected to drive the recovery as households continue to benefit from low interest rates, limited unemployment, and improved asset valuations. A turn in the inventory cycle should also support growth, while fixed investment may remain sluggish for longer, given existing spare capacity and a leveling-off in offshore activity. The contribution from net exports is likely to turn negative as the krone has regained strength and domestic demand is picking up. Near-term inflationary pressures should be kept in check by slower wage growth and the firmer krone, although tight cyclical

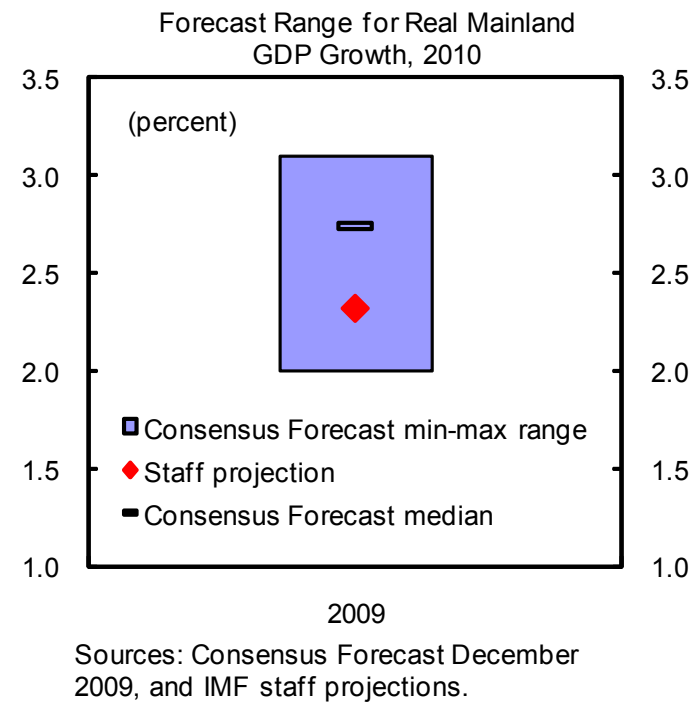
conditions are set to reemerge sooner than in many other advanced economies.

15. The uncertainty around the central forecast is, however, substantial. Mainland growth could pick up faster if the recent rebound in consumer confidence prompted households to considerably lower their saving rates again. A more rapid global recovery would provide a greater boost to exports. Conversely, a renewed weakening of global demand could undermine the recovery, especially if commodity prices were to fall back significantly, dampening offshore investment. Staff analysis also shows that spillovers from financial shocks abroad have a significant effect on Norway's economic growth (Annex III). The main risks to the inflation outlook relate to uncertainty about the speed with which output will return to potential and to exchange rate fluctuations.

Against this background, the mission discussions focused on policies to support a sustained economic recovery and preserve the stability of the financial system. 


\section{Box 2. Real Effective Exchange Rate Assessment}

Staff estimates suggest that the Norwegian krone is broadly in line with fundamentals. The evaluation has been done using the macroeconomic balance approach (MB) and the external sustainability (ES) approach (adjusted for temporary export revenues).

The MB estimates indicate that the exchange rate is close to equilibrium. The equilibrium current account surplus is around 14 percent of GDP, reflecting relatively high hydrocarbon exports and fiscal balances. Staff's medium-term current account projections are in line with this norm.

The standard ERER and ES approaches are not well suited to assessing the krone. These approaches do not take into account the temporary nature of hydrocarbon revenues, and incorrectly interpret large medium-term current account surpluses and net foreign assets (NFA) positions as signs of significant undervaluation.

The adjusted ES approach, in turn, points to a modest overvaluation. ${ }^{1}$ The adjustment incorporates the effect of hydrocarbon reserves depletion on the current account path. Initially, there is a build-up of NFA. When the hydrocarbon resources are exhausted, however, the current account surplus and NFA will decline. The calculated equilibrium exchange rate ensures constant real per capita income from hydrocarbon revenues. The approach suggests overvaluation of 2 percent, based on conservative assumptions about hydrocarbon wealth. $^{2}$

The ULC-based real effective exchange rate appreciation has been somewhat stronger in recent years, reflecting high wage growth in a favorable terms-of-trade environment.

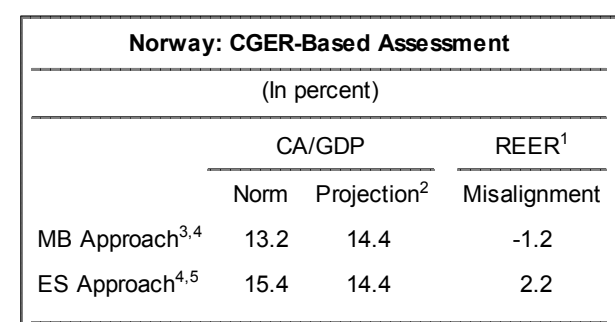

Source: IMF Staff estimates.

${ }^{1}$ Overvaluation is assessed relative to November 2009.

${ }^{2}$ Staff projection of the underlying CA surplus in 2014.

${ }^{3}$ Norway specific oil balance coefficient.

${ }^{4}$ Based on semi-elasticity of the CA/GDP with respect to REER of -0.34

${ }^{5}$ Adjusted for temporary oil-related income. Constant real annuity approach.

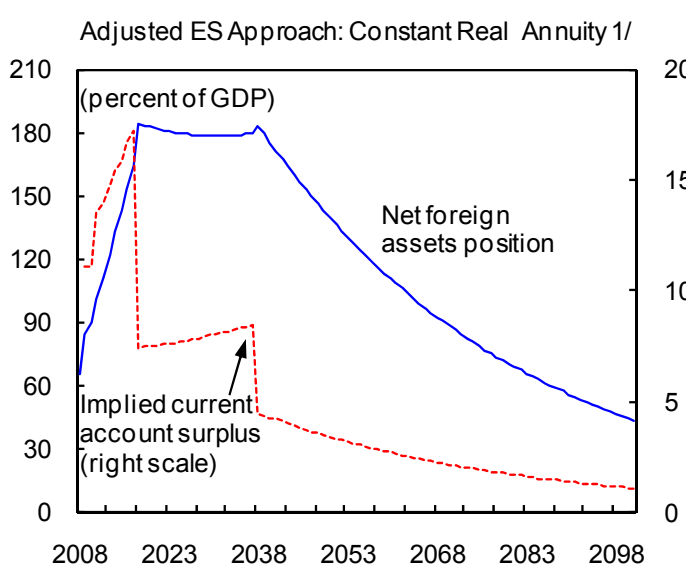

$1 /$ Assuming oil is depleted in 8 and natural gas in 29 years.

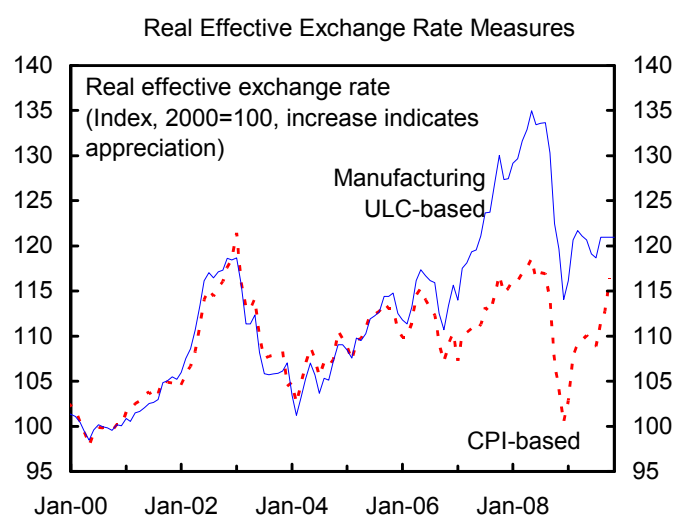

${ }^{1}$ The adjustment methodology is described in IMF WP/09/281 "Exchange Rate Assessments: Methodologies for Oil Exporting Countries" by R. Bems and I. de Carvalho Filho.

${ }^{2}$ Assuming greater hydrocarbon reserves results in a lower estimated overvaluation. 


\section{Policy Discussions}

\section{A. Macroeconomic Policies}

\section{Fiscal Policy}

16. The 2009 fiscal stimulus has been effective in mitigating the economic downturn (Figure 11). The stimulus package was well designed, with an emphasis on timely and, for the most part, temporary spending measures, including stepped-up maintenance work and new public infrastructure investment. The discretionary impulse ( 3 percent of mainland GDP) supplemented automatic stabilizers estimated at $2 \frac{1 / 4}{4}$ percent of mainland GDP.

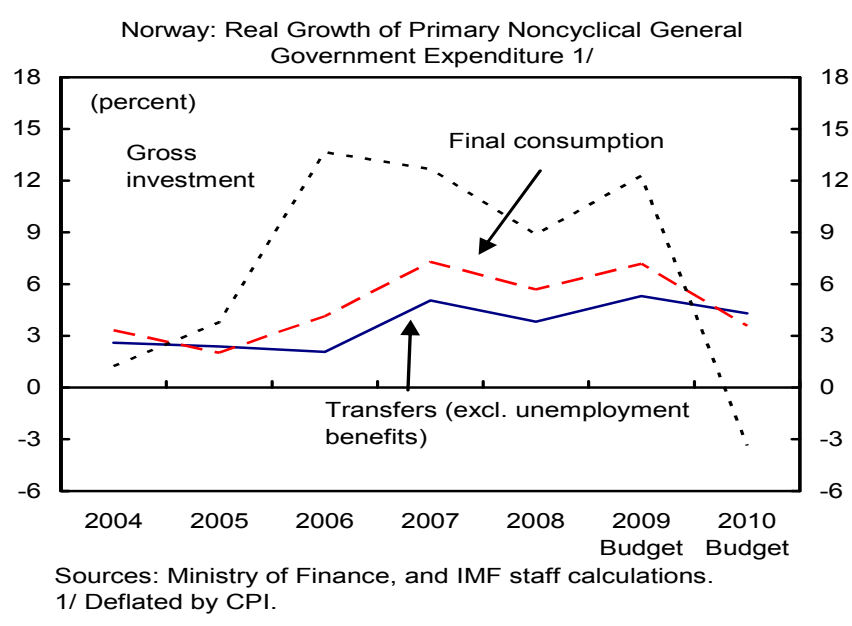

17. The 2010 budget envisages modest additional stimulus. The choice to expand the structural nonoil deficit by a further $1 / 2$ percent of mainland GDP partly reflects the remaining uncertainties about the strength of the recovery. However, staff noted with concern that many of the temporary expenditure measures introduced in 2009 have been replaced by more permanent spending increases, especially for welfare benefits. Given the relatively limited slack in the economy and high nonoil deficit, the mission advocated strict expenditure control in the budget implementation and using any positive revenue surprises for deficit reduction. The authorities concurred that such restraint would also help ensure a more consistent fiscalmonetary policy mix, reducing the risk of excessive exchange rate appreciation. Negative economic surprises, in turn, could be addressed predominantly through monetary policy.

18. Looking beyond 2010, there was agreement that a key policy priority is to reduce the nonoil deficit to the fiscal target. The 2009-10 stimulus has increased the structural nonoil deficit to 5.7 percent of the wealth fund capital, essentially bringing forward the entire fiscal expansion originally envisaged over the next decade under Norway's fiscal guidelines. ${ }^{6}$ Staff and the authorities agreed that reducing the deficit to the 4 percent target in the medium term was important in order to strengthen the credibility of the guidelines, help contain economy-wide cost pressures, regain fiscal space to respond to future adverse shocks, and

\footnotetext{
${ }^{6}$ Norway's fiscal guidelines require the structural nonoil deficit of the central government to be at 4 percent of the (growing) wealth fund capital over time. The goal of the framework is to shield the economy from year-toyear oil price fluctuations, while gradually phasing in the permanent income associated with Norway's hydrocarbon wealth. In addition to allowing free operation of automatic stabilizers, the guidelines permit temporary under- and overshooting of the target for discretionary countercyclical measures. As elaborated in IMF WP 2007/241, the guidelines are broadly appropriate, although staff has cautioned that the implied fiscal expansion over the next decade will necessitate some tightening over the long term to cover the costs of aging.
} 
Figure 11. Norway: Fiscal Developments

To counter the crisis, the government provided very large discretionary fiscal stimulus in 2009 ..

...as witnessed by sharp increases in spending.
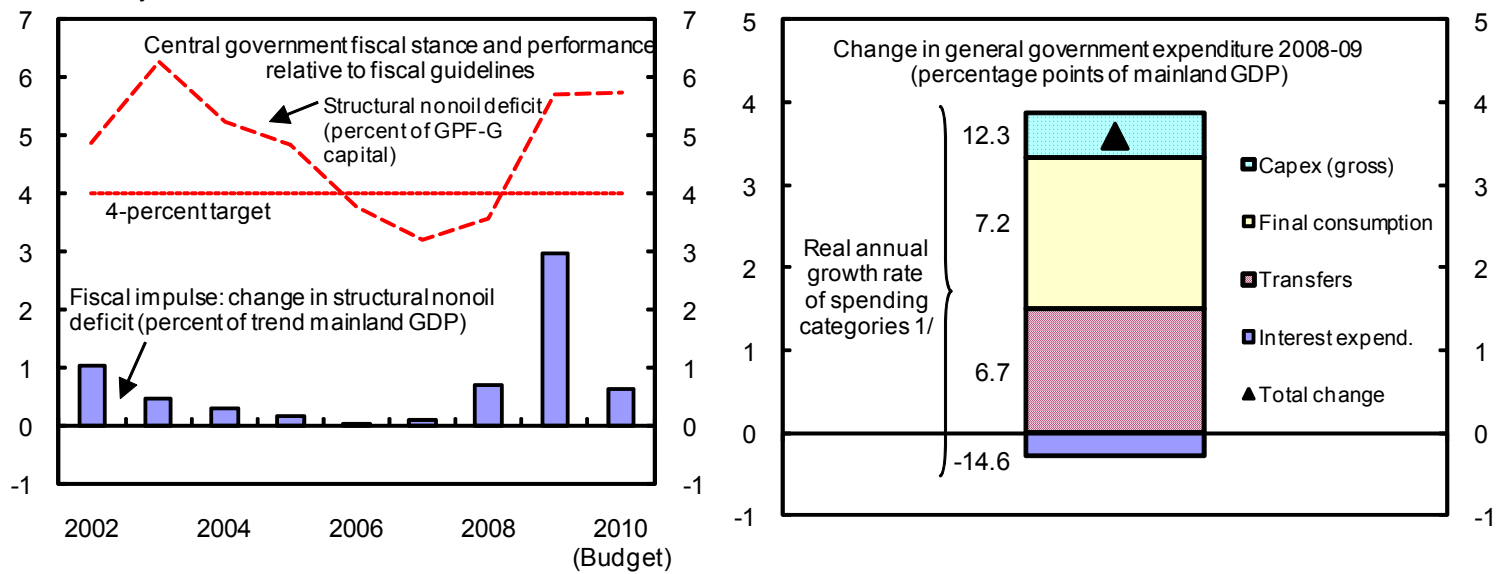

Overall fiscal balances have dropped sharply, but remain in surplus...
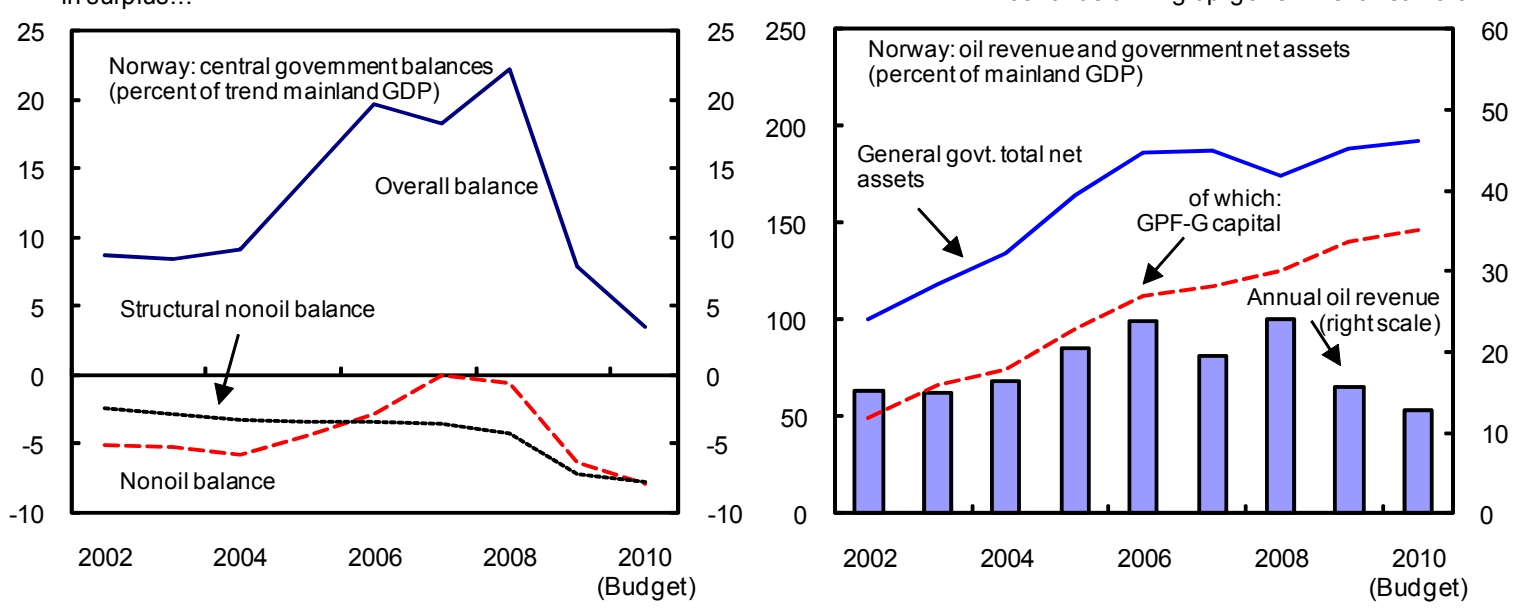

However, the structural nonoil deficit is now well above the 4-percent target, reflecting a legacy of expansionary bias...

...which calls for discretionary tightening in the future, especially given longer-term fiscal challenges.
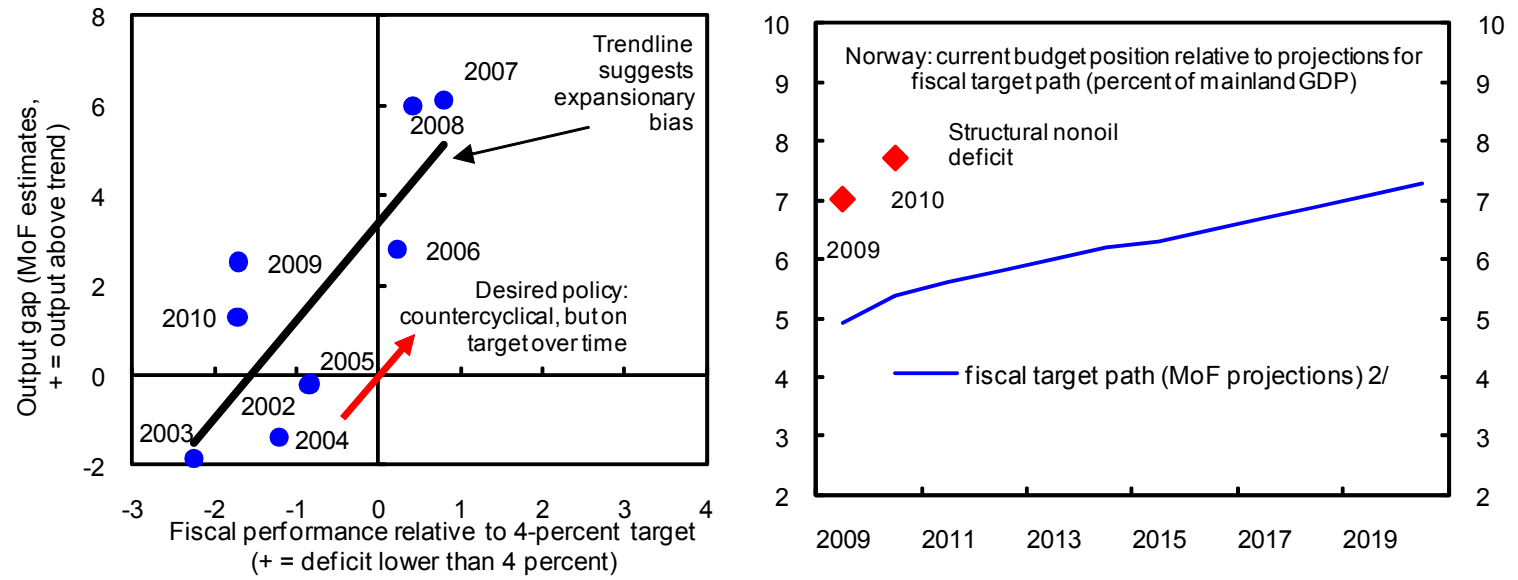

Sources: Ministry of Finance, Norges Bank, and IMF staff calculations. $1 /$ Nominal spending deflated by CPI.

2/ Assumes a constant structural nonoil deficit in real terms until the fiscal target (4 percent of wealth fund capital) is met, and no deviation from the fiscal target thereafter. 
prepare for future aging-related spending increases. Indeed, the Finance Minister publicly announced at the conclusion of the mission that his government is committed to achieving the necessary fiscal consolidation, and that he had an ambition of completing it within the current term of Parliament (by 2013). Staff emphasized that the credibility of this commitment would be strengthened by the early identification of concrete measures. In this context, the government's pledge not to raise the real burden of taxation implies a focus on expenditure-side adjustment.

\section{As a general rule, the flexibility provided under Norway's fiscal guidelines}

should be used symmetrically. The experience of recent years suggests that fiscal loosening during downturns tends to be much more aggressive than the corresponding tightening during good times, implying a slight expansionary bias relative to the 4-percent target. Looking ahead, staff stressed that it was crucial to avoid using the full resource envelope implied by the fiscal guidelines at times of cyclical strength and/or unusually high growth in the fund capital. The authorities agreed and noted that there had been an effort to restrain budget deficits during the boom years.

20. To preserve long-term fiscal sustainability and increase labor supply, the pension reform will need to be supplemented by adjustments in the sickness and disability benefit schemes. Despite the strong current state of Norway's public finances, the fiscal costs of aging are expected to open a sizable financing gap over the longer term. ${ }^{7}$ The authorities' pension reform, to be implemented in 2010-11, aims to encourage longer working lives and limit the rise in pension outlays by tying benefit levels to demographic developments. However, its effectiveness risks being undercut by the large, and rising, inflows into sickness and disability benefit schemes, which have become a major pathway to early retirement. Indeed, the share of Norway's work force receiving such benefits is the highest among all OECD countries.

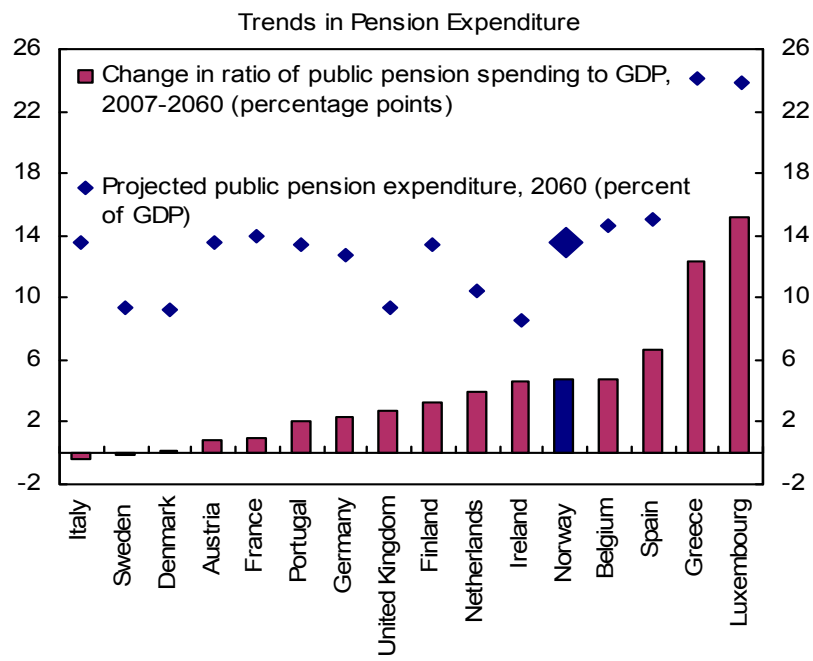

Source: European Commission 2009 Ageing Report.

21. Staff recommended tighter conditionality and enhanced incentives for employees and employers to improve the targeting of benefit schemes. Sickness benefits currently accrue at 100 percent of salaries (up to a cap) and are paid by employers for the first 16 days and by social security thereafter. In line with OECD recommendations, reform efforts could combine stronger oversight by social security physicians, extended employer co-financing,

\footnotetext{
${ }^{7}$ Based on the authorities' projections in the 2010 budget, a financing gap on the order of 6 percent of mainland GDP will emerge by 2060, even after successful implementation of the pension reform. Although these projections are highly sensitive to specific assumptions about oil prices, asset returns, and labor market trends, the projection underscores the need for continued fiscal prudence.
} 
and possibly a moderate reduction in salary replacement rates. Disability benefits should be subject to tighter eligibility requirements, along with more frequent use of partial and temporary benefit awards. The authorities agreed with staff on the urgency of the problem and noted that they are seeking concrete steps to reduce benefit enrollment rates in their negotiations with social partners under the Inclusive Workplace Agreement (to be renewed by March 2010).

22. In the area Property Tax Revenue, 2007

of tax policy, there is a strong case for reducing the massive implicit subsidization of home ownership. Norway's current tax system provides strong incentives to invest in housing as mortgage interest is tax-deductible, the benefit of owneroccupied housing is untaxed, and effective real estate taxes are very low by international standards. As noted

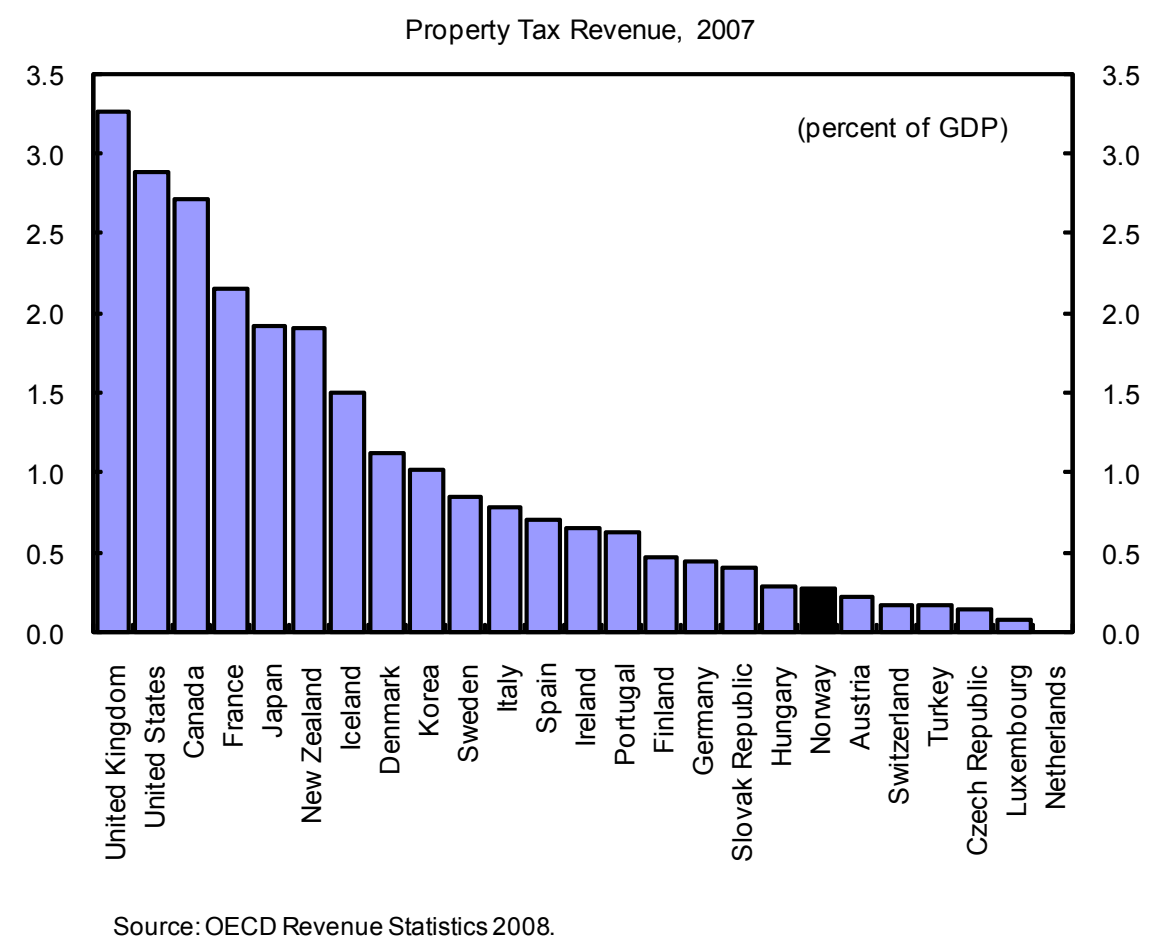
in recent Norges Bank communications, this tax distortion could be a contributing factor to the rich valuation of housing and the high mortgage debt levels in Norway. ${ }^{8}$ To promote efficient private investment decisions and attenuate macroeconomic risk, staff recommended a gradual increase in real estate taxes offset by tax reductions elsewhere. The authorities agreed that such an approach had a theoretical appeal and pointed to changes in the 2010 budget that will bring tax assessments more closely in line with market valuations of housing. Staff welcomed these changes, but noted that as a result of an increase in the taxfree threshold, the net effect was nonetheless a further small cut in effective real estate taxes.

\section{Monetary Policy}

23. Norges Bank responded appropriately to the sharp turn of events in 2008-09 by switching from a fairly tight to a very loose stance within a few months. Through a rapid series of cuts, rates were brought down to a historic low of 1.25 percent by June 2009 . The

\footnotetext{
${ }^{8}$ This view is consistent with the findings of a recent FAD Board paper "Debt Bias and Other DistortionsCrisis-Related Issues in Tax Policy" (SM/09/129, May 2009).
} 
expansionary stance has had a considerable stabilizing effect on activity by providing quick relief to the household sector, whose debt is predominantly at variable rates.

\section{Inflation is expected to remain low in the near term before gradually returning} to target. CPI inflation has recently fallen to 2 percent, although core measures have remained closer to the 2.5 percent target. A strengthening exchange rate, moderating wage growth, and still-subdued demand conditions are expected to keep inflation low over coming months. Looking further ahead, inflation trends will depend on the speed with which the economy returns toward potential and on future exchange rate developments. Under staff's central scenario, inflation would gradually converge to target by end-2011 (Figure 12). Consistent with this outlook, medium-term inflation expectations have remained wellanchored, underscoring the credibility of Norway's monetary policy framework.

25. The strengthening macroeconomic outlook calls for a gradual move to a tighter stance in the coming months. Reflecting Norway's more favorable cyclical position, Norges Bank was among the first central banks to start raising rates again, with two consecutive 25 basis point hikes in October and December 2009. Prospects for a continued economic recovery, a relatively tight labor market, and the macroeconomic risks associated with strong house price appreciation all warrant some further normalization of policy rates over the coming quarters, as foreshadowed in recent Norges Bank communications. However, the tightening should be gradual to avoid undermining the recovery amid stillsignificant uncertainty. Staff also noted that policy rates above the lower bound and a wellfunctioning transmission mechanism imply that monetary policy remains a powerful tool to deal with possible negative demand shocks.

\section{B. Strengthening the Financial System}

26. The Norwegian financial system has weathered the crisis well, although credit risks remain elevated. Even though the economic cycle appears to be turning, some sectors are facing a period of protracted cyclical weakness. There is large overcapacity in shipping, and ship-building orders have declined sharply. Lower collateral values and weaker profitability in commercial real estate may also prompt higher credit losses. These two sectors together account for about half of all commercial loans.

\section{Another potential vulnerability is the high household indebtedness, combined} with a richly valued housing market. Banks view mortgage loans as individually safe, given full recourse and historically low default rates. In fact, nearly a quarter of all newly originated mortgages, excluding refinancing, have loan-to-value ratios above 100 percent. However, there is a considerable systemic risk: even if households continue to service their mortgages in the case

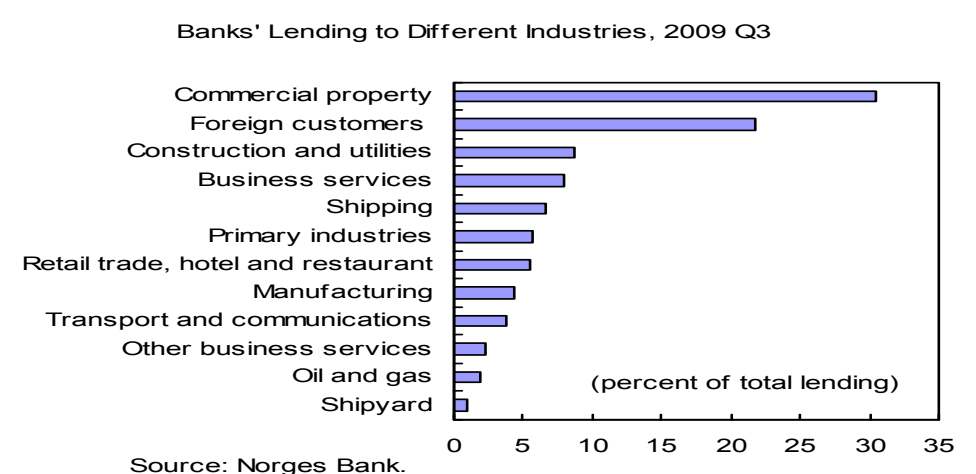


Figure 12. Norway: Price Developments

Headline inflation has eased sharply since mid-2008, and core inflation is now also slightly below the 2.5percent target ...

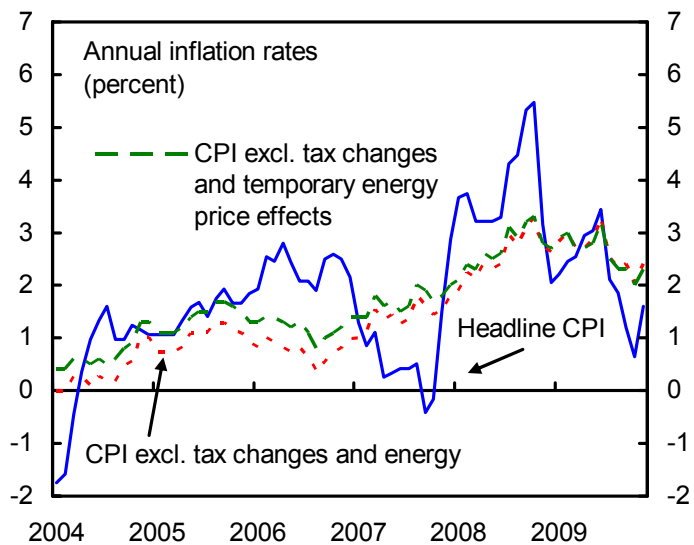

Producer price inflation dropped sharply, but has recently ticked up again, in sync with trends in energy costs.

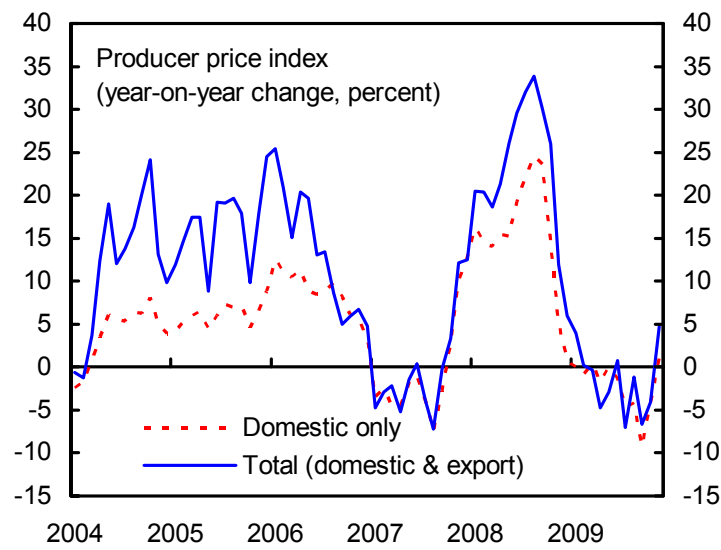

...and subdued growth in money and credit.

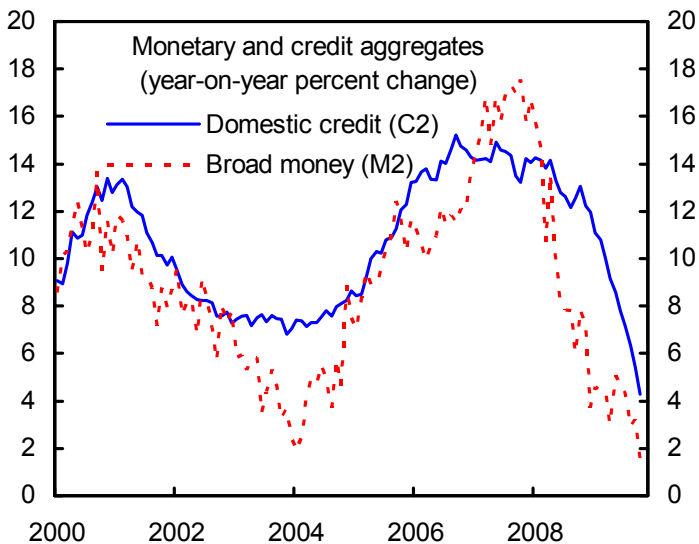

Sources: Haver Analytics, and IMF staff calculations. ...as the import price effect of a (temporarily) weaker krone has been more than offset by lower commodity prices and weaker demand for domestic goods and services.

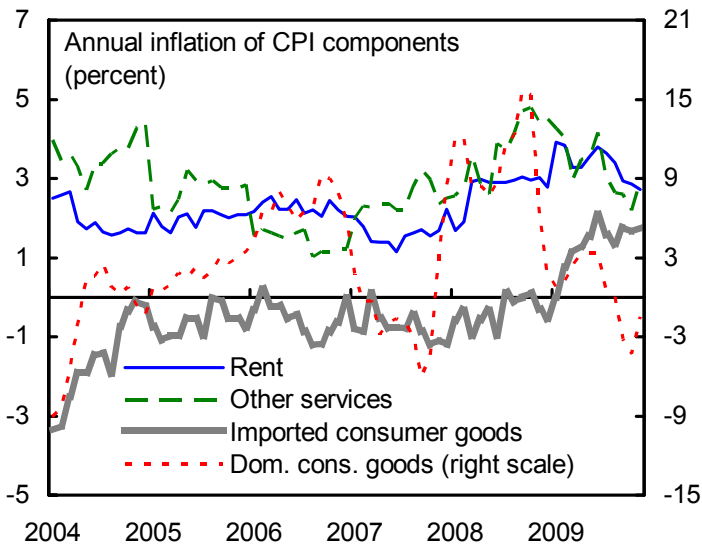

Still, near-term price pressures appear to be contained, given moderating wage dynamics..

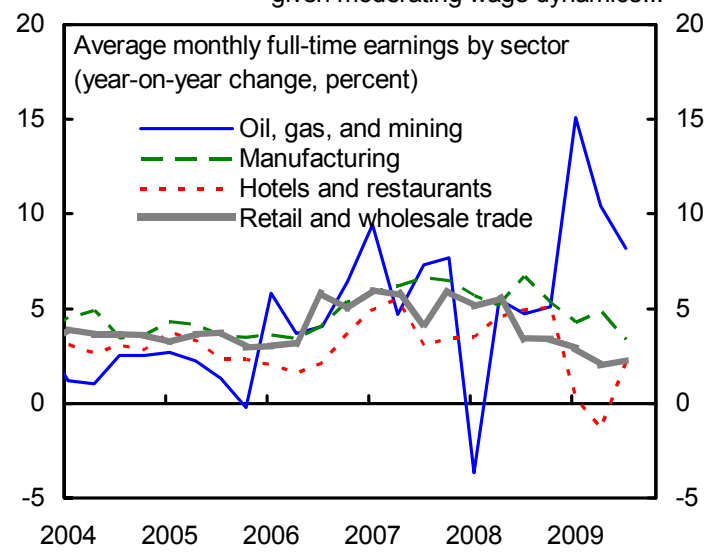

Meanwhile, medium-term inflation expectations have remained in line with the target.

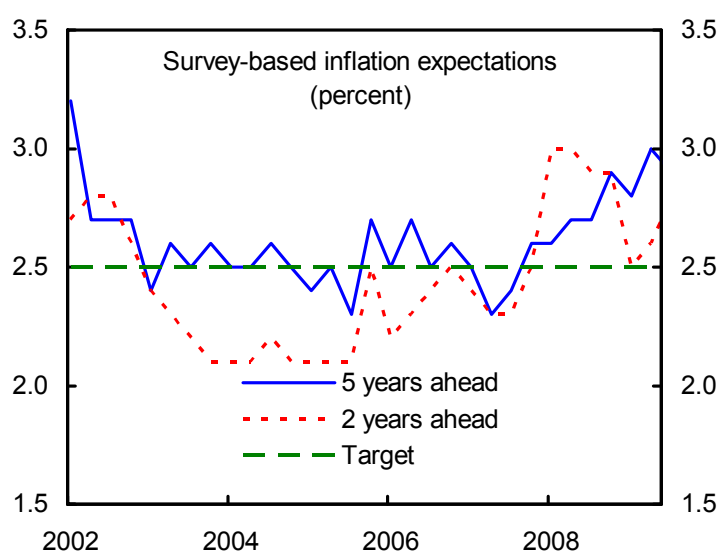


of a negative economic shock, the implied retrenchment of consumption could amplify the downturn, with adverse effects on banks' broader credit portfolios. To contain this risk, staff recommended the introduction of targeted prudential measures, along with a phasing-out of the existing large tax incentives for housing investment. The authorities agreed in principle with the need for macroprudential safeguards.

28. Against this backdrop, banks have taken steps to raise additional capital in recent months. In September 2009, a number of institutions announced their intention to raise capital, both from private sources and from the State Finance Fund. ${ }^{9}$ Stress tests reported in Norges Bank's December 2009 Financial Stability Report suggest that under its baseline macroeconomic scenario (which is close to staff's projections), bank capitalization will remain quite strong. Even in the very low-probability stress scenario, the tier 1 ratio for all large banks would remain above the regulatory minimum over the next three years (Annex IV). Overall, with the strengthening of capital buffers, banks sector appear well placed to absorb possible credit losses, while maintaining credit provision for worthy borrowers.

\section{There is scope for further strengthening of Norway's general prudential}

framework. Norway already implements all relevant European Union directives. Given the regional character of the Nordic financial market, there is a case for seeking even higher common standards across the region where appropriate. A key lesson from the crisis is that there should be greater emphasis on the management of liquidity risks. In addition, excessive balance sheet growth needs to be restrained, for example through the adoption a maximum gross leverage ratio. The authorities confirmed their support for EU-wide initiatives in these areas, and emphasized that any further enhancements in the prudential framework would be most effective if implemented simultaneously across the whole Nordic region.

\section{The crisis has also highlighted the need for close cross-country cooperation in} the supervision, regulation, and resolution of internationally active banks. The Memoranda of Understanding (MoUs) on cross-border financial stability and the agreements within the Nordic-Baltic region and between Norway and the European Union should provide a good foundation for close collaboration. The authorities agreed with staff that it would be especially important for supervisors and regulators across countries to join forces to identify emerging problems early and take coordinated preventive action.

31. With the normalization of market conditions, most crisis measures have already been phased out. The provision of longer-term NOK loans and exceptional foreignexchange funding contributed to the stabilization of market conditions, allowing Norges Bank to stop these operations in early 2009. In October 2009, Norges Bank announced that the temporary relaxation of collateral requirements would be reversed shortly. Finally, the

\footnotetext{
${ }^{9}$ The authorities set up the State Finance Fund in early 2009 to provide public capital to qualifying banks on a voluntary basis. Thirty four banks, accounting for 15 percent of total assets of the banking system, applied for a total of NOK 6.7 billion (US\$1.16 billion) of public capital by the end-September deadline. Separately, two of the largest banks - DnB Nor and Sparebank 1 SR - have announced plans to raise US $\$ 2.6$ billion through rights issues and private placements (increasing their respective capital ratios by about $1 \frac{1}{2}-2$ percentage points).
} 
government's covered bond swap program, which had exhausted about two-thirds of the maximum allocation, was terminated in late 2009. Staff welcomed these timely exit decisions and suggested that plans should be made for winding down the corporate bond purchase program.

\section{Staff Appraisal}

32. The Norwegian economy has already returned to growth after a relatively mild recession. The economy's resilience has been bolstered by substantial fiscal and monetary stimulus, strong activity in the oil and gas sector, limited dependence on the hardest-hit segments of manufacturing, high public-sector employment, and a relatively stable financial system.

33. Looking ahead, the economic recovery is expected to continue. Mainland real GDP is projected to grow at around 2 $\frac{1 / 4}{4}$ percent in 2010, with private domestic demand progressively replacing public spending as the main driver of growth. Private consumption should strengthen as households continue to benefit from low interest rates, steady employment, and higher asset prices. A turn in the inventory cycle should also support activity. Uncertainty about the strength of the global recovery is the main risk to the outlook.

34. Model-based assessments suggest that the value of the krone is broadly in line with fundamentals. In addition, the CPI-based real effective exchange rate was close to its long-term average in the third quarter of 2009. However, the manufacturing ULC-based real effective exchange rate has appreciated more strongly in recent years, reflecting high domestic wage growth is a favorable terms-of-trade environment. Continued increase in wage costs could cause strains in some export-oriented sectors in the future, especially if the terms of trade were to turn around.

35. The large fiscal stimulus implemented in $\mathbf{2 0 0 9}$ has been effective in softening the economic downturn, but may prove difficult to rein in. The 2009 stimulus was timely and well-designed, with an emphasis on expenditure measures. However, it is unfortunate that many of the temporary spending measures introduced in 2009 have been replaced by more permanent expenditure increases in the 2010 budget. The expected rise in social security spending is particularly large. Given the relatively limited slack in the economy and the high nonoil deficit, strict expenditure control in the 2010 budget implementation is warranted. In particular, any upside surprises to revenue should be used to reduce the deficit. Spending restraint will also help ensure a consistent fiscal-monetary policy mix.

36. In the medium term, a steady reduction of the nonoil deficit will be appropriate as the economic recovery takes hold. To reaffirm commitment to the fiscal guidelines, regain flexibility for discretionary action in response to adverse shocks, and help preserve competitiveness, future budget plans should aim to reduce the structural nonoil deficit to the 4-percent target, preferably within the current term of Parliament. The credibility of fiscal plans will be enhanced by the early identification of concrete measures to achieve the desired consolidation. An emphasis on expenditure-side measures, as implied by the government's commitment not to raise the real level of taxes, appears appropriate. 
37. Effective reform of the sickness and disability benefit schemes will be critical to contain expenditure growth. The authorities' pension reform appropriately aims to encourage longer working lives and contain the rise of pension outlays by tying benefits to demographic developments. For the reform to be successful in achieving these goals, however, it will need to be supplemented by concrete steps to curb the very high inflows into sickness and disability benefit schemes. Measures have to be geared toward improving the incentives of employees and employers, in both the private and the public sector, and could include greater use of cost-sharing and increased reliance on specialized social insurance physicians in assessing and verifying eligibility for benefits.

38. Once deficits have been brought down to 4 percent, the flexibility to deviate temporarily from the fiscal target for stabilization purposes should be used more symmetrically. Norway's fiscal guidelines provide a good general fiscal framework. In their implementation, it is important to aim for a more restrictive fiscal stance during periods of strong economic activity to ensure that the 4-percent target is met over time. Excessive public spending can push up already-high cost levels further, with adverse consequences for the competitiveness of the broader economy.

39. Given the relatively favorable cyclical position of Norway's economy, Norges Bank appropriately has been one of the first central banks to start raising rates again. The strengthening outlook, a relatively tight labor market, and the macroeconomic risks implied by strong house price appreciation all point to the need for a continuing withdrawal of the extraordinary monetary stimulus in the period ahead, as envisaged in the October 2009 monetary policy report. Nonetheless, the tightening should proceed at a gradual pace to avoid undermining the economic recovery.

40. The financial system has weathered the global financial crisis well, but

vulnerabilities remain. The timely measures taken by the authorities to support liquidity and bank capital have helped limit the domestic fallout from the global crisis. Norway's financial institutions have also benefited from a robust domestic economy, low exposure to toxic assets, and a sound prudential framework. However, a further deterioration of credit quality in shipping and commercial real estate remains a risk. Against this backdrop, recent efforts to increase capital buffers in the banking system are welcome. With stronger capital positions, banks should be able to absorb possible credit losses, while maintaining credit provision for worthy borrowers. To contain the macroprudential risks associated with high household debt and high loan-to-value ratios for mortgage loans, targeted prudential measures could be considered. The distortion that arises from large existing tax incentives for housing investment also needs to be addressed directly, for example through an increase of property taxes offset by tax reductions elsewhere.

41. Further strengthening of the prudential framework and closer cross-country cooperation in supervision and regulation will enhance the resilience of the financial system. Efforts in this area should be based on international practices as promulgated by the Basel Committee and embodied in amended European Union Directives. Given the regional character of the Nordic financial market, close coordination with Norway's neighbors could be used to ensure higher common standards as appropriate. In this context, particular priority should be placed on strengthening the management of liquidity risks. To limit excessive 
balance sheet growth, supplementing existing capital adequacy rules with a maximum gross leverage ratio could be considered. Finally, enhanced cross-country cooperation would help identify emerging problems early and take coordinated preventive action.

It is proposed that the next Article IV consultation be held on the usual 24-month cycle. 
Table 1. Norway: Selected Economic and Social Indicators, 2004-10

\begin{tabular}{|c|c|c|c|c|c|c|c|}
\hline & 2004 & 2005 & 2006 & 2007 & 2008 & $\begin{array}{c}2009 \\
\text { Proj. }\end{array}$ & $\begin{array}{l}2010 \\
\text { Proj. }\end{array}$ \\
\hline \multicolumn{8}{|l|}{ Real economy (change in percent) } \\
\hline Real GDP & 3.9 & 2.5 & 2.1 & 2.7 & 1.8 & -1.1 & 1.2 \\
\hline Real mainland GDP 1/ & 4.4 & 4.4 & 4.6 & 5.6 & 2.2 & -1.2 & 2.3 \\
\hline Domestic demand & 6.7 & 5.5 & 5.6 & 5.0 & 2.5 & -2.3 & 2.4 \\
\hline Private consumption & 5.6 & 4.0 & 4.8 & 5.4 & 1.3 & -0.1 & 3.3 \\
\hline Private mainland fixed investment & 11.3 & 15.9 & 12.0 & 17.2 & 0.1 & -15.4 & -3.2 \\
\hline Unemployment rate (percent of labor force) & 4.5 & 4.6 & 3.4 & 2.5 & 2.6 & 3.1 & 3.7 \\
\hline Output gap (mainland economy, - = output below potential) & -1.9 & -0.6 & 1.0 & 3.5 & 3.1 & -0.3 & -0.1 \\
\hline CPI (average) & 0.5 & 1.5 & 2.3 & 0.7 & 3.8 & 2.2 & 1.4 \\
\hline CPI (end of period) & 1.1 & 1.8 & 2.2 & 2.8 & 2.1 & 2.0 & 1.6 \\
\hline Gross national saving (percent of GDP) & 32.7 & 37.4 & 39.2 & 39.1 & 41.6 & 35.9 & 36.7 \\
\hline Gross domestic investment (percent of GDP) & 20.0 & 21.2 & 22.0 & 23.6 & 22.7 & 21.8 & 20.8 \\
\hline \multicolumn{8}{|l|}{ Public finance } \\
\hline \multicolumn{8}{|l|}{ Central government (fiscal accounts basis) 2/ } \\
\hline Overall balance (percent of GDP) & 7.1 & 10.8 & 14.4 & 13.9 & 15.9 & 6.2 & 2.6 \\
\hline Structural nonoil balance (percent of mainland trend GDP) $3 /$ & -3.2 & -3.4 & -3.4 & -3.5 & -4.2 & -7.2 & -7.8 \\
\hline in percent of Government Pension Fund-Global capital 4/ & -5.2 & -4.8 & -3.7 & -3.2 & -3.6 & -5.7 & -5.7 \\
\hline \multicolumn{8}{|l|}{ General government (national accounts basis, percent of GDP) 5/ } \\
\hline Overall balance & 11.1 & 15.1 & 18.5 & 17.8 & 18.7 & 7.3 & 8.5 \\
\hline Net financial assets & 86.5 & 99.6 & 109.4 & 115.1 & 112.9 & 134.7 & 136.2 \\
\hline of which: Capital of Government Pension Fund-Global & 58.3 & 71.8 & 82.5 & 88.8 & 89.4 & 109.5 & 112.6 \\
\hline \multicolumn{8}{|l|}{ Money and credit (end of period, 12-month percent change) 6/ } \\
\hline Broad money, M2 & 7.5 & 11.7 & 13.7 & 16.7 & 3.7 & 1.5 & $\ldots$ \\
\hline Domestic credit, C2 & 8.6 & 13.2 & 14.3 & 14.0 & 12.0 & 5.1 & $\ldots$ \\
\hline \multicolumn{8}{|l|}{ Interest rates (year average, in percent) } \\
\hline Three-month interbank rate & 2.0 & 2.2 & 3.1 & 5.0 & 6.2 & 2.5 & $\ldots$ \\
\hline Ten-year government bond yield & 4.4 & 3.7 & 4.1 & 4.8 & 4.5 & 4.0 & $\ldots$ \\
\hline \multicolumn{8}{|l|}{ Balance of payments (percent of mainland GDP) } \\
\hline Current account balance & 16.4 & 21.8 & 23.5 & 18.6 & 26.0 & 18.7 & 21.7 \\
\hline Balance of goods and services & 17.4 & 22.1 & 24.7 & 20.2 & 26.8 & 17.5 & 20.9 \\
\hline Net exports of oil and gas & 24.8 & 29.3 & 31.4 & 27.5 & 33.7 & 24.1 & 27.6 \\
\hline Exports of goods and services (volume change in percent) & 1.1 & 1.1 & 0.0 & 2.3 & 0.9 & -5.2 & 0.2 \\
\hline Imports of goods and services (volume change in percent) & 8.8 & 8.7 & 8.4 & 8.6 & 2.2 & -10.5 & 3.5 \\
\hline Terms of trade (change in percent) & 7.7 & 15.6 & 11.9 & -1.6 & 12.2 & $\ldots$ & $\ldots$ \\
\hline International reserves (end of period, in billions of US dollars) & 44.4 & 47.0 & 56.5 & 61.1 & 51.1 & $\ldots$ & $\ldots$ \\
\hline \multicolumn{8}{|l|}{ Fund position (as of November 30, 2009) } \\
\hline Holdings of currency (percent of quota) & & & & & & & 80.6 \\
\hline Holdings of SDR (percent of allocation) & & & & & & & 102.7 \\
\hline Quota (SDR millions) & & & & & & & $1,671.7$ \\
\hline \multicolumn{8}{|l|}{ Exchange rates (end of period) } \\
\hline Exchange rate regime & & & & & \multicolumn{3}{|c|}{ Free float } \\
\hline Bilateral rate (NOK/USD) 7/ & 6.0 & 6.8 & 6.3 & 5.4 & 7.0 & 5.9 & $\ldots$ \\
\hline Nominal effective rate $(2000=100) 6 /$ & 110.6 & 111.5 & 110.9 & 116.5 & 100.7 & 107.9 & $\ldots$ \\
\hline Real effective rate $(2000=100) 6 /$ & 109.7 & 110.7 & 110.3 & 115.3 & 100.4 & 107.1 & $\ldots$ \\
\hline \multicolumn{8}{|l|}{ Social Indicators (reference year): } \\
\hline \multicolumn{8}{|c|}{ Per capita GDP (2008): $\$ 96,100$; Income distribution (ratio of after-tax income received by top and bottom 20th percentile, 2007): 3.4 ; } \\
\hline \multicolumn{8}{|c|}{ At-risk-of-poverty rate (2007): 11.7; Life expectancy at birth (2008): male: 78.3, female: 82.9 . } \\
\hline Population (2008): 4.69 million; Population density (2008): 14. & ants per & uare $\mathrm{km}$ & & & & & \\
\hline
\end{tabular}

Sources: Ministry of Finance; Norges Bank; Statistics Norway; International Financial Statistics; and IMF staff estimates and projections.

$1 /$ Excludes items related to petroleum exploitation and ocean shipping.

2/ Projections based on authorities' 2010 budget.

3/ Authorities' key fiscal policy variable; excludes oil-related revenue and expenditure, GPF-G income, as well as cyclical effects.

4/ Over-the-cycle deficit target: 4 percent.

5/ Staff projections, incorporating higher 2010 oil price assumption than the authorities' 2010 budget.

$6 / 2009$ data as of end-October.

7/ 2009 data as of December 18, 2009. 
Table 2. Norway: Medium-Term Indicators, 2006-14

\begin{tabular}{|c|c|c|c|c|c|c|c|c|c|}
\hline & nual per & ent cha & ge, unle & s notec & otherwis & & & & \\
\hline & 2006 & 2007 & 2008 & 2009 & 2010 & 2011 & 2012 & 2013 & 2014 \\
\hline & & & & \multicolumn{6}{|c|}{ Projections } \\
\hline Real mainland GDP & 4.6 & 5.6 & 2.2 & -1.2 & 2.3 & 2.3 & 2.4 & 2.5 & 2.5 \\
\hline Real GDP & 2.1 & 2.7 & 1.8 & -1.1 & 1.2 & 1.7 & 1.9 & 2.0 & 2.0 \\
\hline Real Domestic Demand & 5.6 & 5.0 & 2.5 & -2.3 & 2.4 & 2.5 & 2.6 & 2.6 & 2.6 \\
\hline Public consumption & 1.9 & 3.0 & 4.1 & 5.7 & 2.3 & 2.0 & 2.0 & 2.0 & 2.0 \\
\hline Private consumption & 4.8 & 5.4 & 1.3 & -0.1 & 3.3 & 3.0 & 2.8 & 2.8 & 2.8 \\
\hline Gross fixed investment & 11.7 & 12.5 & 1.4 & -7.5 & -2.1 & 2.1 & 2.9 & 3.0 & 3.1 \\
\hline Public & 11.6 & 9.6 & 4.7 & 7.3 & 2.0 & 1.0 & 1.5 & 2.0 & 2.5 \\
\hline Private mainland & 12.0 & 17.2 & 0.1 & -15.4 & -3.2 & 3.6 & 4.2 & 4.3 & 4.3 \\
\hline Private offshore & 11.1 & 4.0 & 2.6 & 2.3 & -2.5 & 0.0 & 1.0 & 1.0 & 1.0 \\
\hline Final domestic demand & 5.7 & 6.9 & 1.9 & -0.7 & 1.7 & 2.5 & 2.6 & 2.6 & 2.6 \\
\hline Stockbuilding $1 /$ & 0.1 & -1.4 & 0.5 & -1.4 & 0.6 & 0.0 & 0.0 & 0.0 & 0.0 \\
\hline External balance 1/ & -2.3 & -1.4 & -0.3 & 0.8 & -0.9 & -0.5 & -0.3 & -0.3 & -0.3 \\
\hline Exports of G\&S & 0.0 & 2.3 & 0.9 & -5.2 & 0.2 & 1.0 & 1.5 & 1.6 & 1.6 \\
\hline Mainland good exports & 6.2 & 8.5 & 4.3 & -8.8 & 2.8 & 2.5 & 2.8 & 3.0 & 3.0 \\
\hline Offshore good exports & -6.2 & -2.5 & -1.7 & -2.9 & -2.2 & -0.5 & -0.1 & -0.1 & -0.1 \\
\hline Imports of G\&S & 8.4 & 8.6 & 2.2 & -10.5 & 3.5 & 3.2 & 3.3 & 3.3 & 3.4 \\
\hline \multicolumn{10}{|l|}{ Labor Market } \\
\hline Employment & 3.2 & 3.4 & 3.3 & -0.4 & -0.3 & 0.6 & 0.7 & 0.8 & 0.8 \\
\hline Unemployment rate (\%) & 3.4 & 2.5 & 2.6 & 3.1 & 3.7 & 3.6 & 3.5 & 3.5 & 3.5 \\
\hline \multicolumn{10}{|l|}{ Prices and Wages } \\
\hline GDP deflator & 8.7 & 2.4 & 10.0 & -5.5 & 5.1 & 2.9 & 2.7 & 2.8 & 2.8 \\
\hline Consumer prices (avg) & 2.3 & 0.7 & 3.8 & 2.2 & 1.4 & 2.1 & 2.5 & 2.5 & 2.5 \\
\hline Consumer prices (eop) & 2.2 & 2.8 & 2.1 & 1.5 & 1.6 & 2.5 & 2.5 & 2.5 & 2.5 \\
\hline \multicolumn{10}{|l|}{ Manufacturing } \\
\hline Hourly compensation & 6.2 & 4.9 & 5.9 & $\ldots$ & $\ldots$ & $\ldots$ & $\ldots$ & $\ldots$ & $\ldots$ \\
\hline Productivity & -2.0 & -0.5 & 0.3 & $\ldots$ & $\ldots$ & $\ldots$ & $\ldots$ & $\ldots$ & $\ldots$ \\
\hline Unit labor costs & 8.4 & 5.4 & 5.5 & $\cdots$ & $\cdots$ & $\cdots$ & $\cdots$ & $\cdots$ & $\cdots$ \\
\hline \multicolumn{10}{|l|}{ Financial Indicators } \\
\hline \multicolumn{10}{|l|}{ Fiscal balance 2/ } \\
\hline General government & 18.5 & 17.8 & 18.7 & 7.3 & 8.5 & 9.3 & 9.6 & 10.0 & 9.9 \\
\hline of which: nonoil & -1.2 & 0.1 & -1.8 & -6.4 & -6.7 & -6.1 & -5.6 & -5.2 & -5.1 \\
\hline \multicolumn{10}{|l|}{ Interest rates (percent) } \\
\hline Short-term & 3.1 & 5.0 & 6.2 & 2.5 & $\ldots$ & $\ldots$ & $\ldots$ & $\ldots$ & $\ldots$ \\
\hline Long-term & 4.1 & 4.8 & 4.5 & 4.0 & $\ldots$ & $\ldots$ & $\ldots$ & $\ldots$ & $\ldots$ \\
\hline Exchange rate (NOK/US\$) & 6.4 & 5.9 & 5.6 & $\cdots$ & $\cdots$ & $\cdots$ & $\cdots$ & $\cdots$ & $\cdots$ \\
\hline \multicolumn{10}{|l|}{ External Sector 2/ } \\
\hline Current account balance & 17.2 & 14.1 & 18.6 & 14.1 & 15.9 & 15.5 & 15.0 & 14.8 & 14.4 \\
\hline Trade balance & 74.8 & 76.2 & 77.0 & 68.8 & 69.5 & 70.0 & 70.2 & 70.5 & 70.7 \\
\hline
\end{tabular}

Source: WEO.

$1 /$ Contribution to growth.

2/ National accounts definition; in percent of GDP. 
Table 3. Norway: Financial Soundness Indicators: Non-Banks, 2003-09

(End-period, in percent)

\begin{tabular}{|c|c|c|c|c|c|c|c|}
\hline & 2003 & 2004 & 2005 & 2006 & 2007 & 2008 & $20091 /$ \\
\hline \multicolumn{8}{|l|}{ Insurance sector } \\
\hline \multicolumn{8}{|l|}{ Solvency ratio (margin/required margin) } \\
\hline Life insurance companies & 160.0 & 171.0 & 175.0 & 193.0 & 244.0 & 223.0 & $\ldots$ \\
\hline Non-life insurance companies & 512.0 & 549.0 & 613.0 & 616.0 & 632.0 & 601.0 & $\ldots$ \\
\hline \multicolumn{8}{|l|}{ Households } \\
\hline Household debt burden as percent of gross disposable income 2/ & 146.1 & 156.3 & 166.4 & 179.3 & 187.9 & 194.0 & $\ldots$ \\
\hline Household interest burden as percent of gross disposable income 2/ & 6.7 & 4.8 & 4.4 & 4.7 & 6.1 & 8.0 & \\
\hline Household net financial wealth as percent of after-tax income & $\ldots$ & 48.0 & 53.0 & 53.0 & 44.0 & 25.0 & $\ldots$ \\
\hline \multicolumn{8}{|l|}{ Nonfinancial enterprises } \\
\hline Return on equity $3 /$ & 2.1 & 8.7 & 21.0 & 26.1 & 19.0 & -26.1 & 26.5 \\
\hline Operating margin $3 /$ & 0.0 & 3.0 & 9.7 & 12.4 & 10.1 & -4.0 & 16.2 \\
\hline Total debt to equity (percent, without financial corporations) & 169.5 & 166.7 & 148.8 & 148.1 & 146.9 & 225.7 & $\ldots$ \\
\hline Bankruptcy rate & 1.8 & 1.5 & 1.2 & 1.0 & 0.9 & 1.1 & $\ldots$ \\
\hline \multicolumn{8}{|l|}{ Memorandum items } \\
\hline Total financial system assets (in billions of NOK) 4/ & $2,927.6$ & $3,122.1$ & $3,618.9$ & $4,235.1$ & $5,003.7$ & $6,109.5$ & $6,146.2$ \\
\hline of which: five largest banks (in percent of total assets) & 35.9 & 35.2 & 36.5 & 38.7 & 39.4 & 40.9 & 39.0 \\
\hline
\end{tabular}

Sources: Eurostat, Norges Bank, Statistics Norway; and IMF staff calculations and projections.

1/ For 2009, annualized figures, where applicable for income statement, end-of-Q3 for balance-sheet, and IMF staff projections for GDP.

2/ Average level for each calendar year.

3/ Projection for 2009 Q3

4/ Excludes mutual funds assets. 
Table 4. Norway: Financial Soundness Indicators: Banks, 2003-09

(End-period, in percent)

\begin{tabular}{|c|c|c|c|c|c|c|c|}
\hline & 2003 & 2004 & 2005 & 2006 & 2007 & 2008 & $20091 /$ \\
\hline \multicolumn{8}{|l|}{ Capital Adequacy } \\
\hline \multirow{2}{*}{$\begin{array}{l}\text { Regulatory capital to risk-weighted assets } 2 / \\
\text { of which: Five largest banks }\end{array}$} & 12.4 & 12.2 & 11.9 & 11.2 & 11.7 & 11.2 & 12.1 \\
\hline & 11.3 & 10.8 & 10.9 & 10.3 & 11.1 & 10.5 & 11.3 \\
\hline \multirow{2}{*}{$\begin{array}{l}\text { Regulatory Tier I capital to risk-weighted assets } 2 / \\
\text { of which: Five largest banks }\end{array}$} & 9.7 & 9.8 & 9.5 & 8.7 & 9.3 & 8.6 & 9.5 \\
\hline & 8.4 & 8.1 & 8.1 & 7.1 & 8.3 & 7.4 & 8.3 \\
\hline \multirow{2}{*}{$\begin{array}{l}\text { Regulatory Capital/Total assets } \\
\text { of which: Five largest banks }\end{array}$} & 7.5 & 7.6 & 7.4 & 7.0 & 6.4 & 5.9 & 6.0 \\
\hline & 7.4 & 7.3 & 7.3 & 7.0 & 6.2 & 5.8 & 5.8 \\
\hline \multicolumn{8}{|l|}{ Asset quality and exposure $3 /$} \\
\hline \multirow{2}{*}{$\begin{array}{l}\text { Nonperforming loans to total gross loans } \\
\text { of which: Five largest banks }\end{array}$} & 1.6 & 1.0 & 0.7 & 0.6 & 0.5 & 0.8 & 1.1 \\
\hline & 1.4 & 0.9 & 0.5 & 0.4 & 0.4 & 0.6 & 1.0 \\
\hline \multirow{2}{*}{$\begin{array}{l}\text { Nonperforming loans net of loan-loss provisions to Tier I Capital } \\
\text { of which: Five largest banks }\end{array}$} & 0.7 & -3.3 & -0.9 & 2.1 & 2.4 & 5.4 & 6.3 \\
\hline & -0.6 & -3.6 & -1.7 & 2.4 & 2.3 & 5.6 & 6.4 \\
\hline \multirow{2}{*}{$\begin{array}{l}\text { Loan-loss provisions to nonperforming loans } \\
\text { of which: Five largest banks }\end{array}$} & 96.8 & 124.7 & 109.3 & 74.2 & 67.0 & 53.5 & 60.3 \\
\hline & 102.8 & 127.1 & 120.4 & 64.7 & 60.4 & 40.8 & 55.5 \\
\hline Loans-to-assets (percent) & 79.5 & 81.3 & 81.0 & 77.6 & 77.0 & 68.1 & 64.9 \\
\hline \multicolumn{8}{|l|}{ Sectoral distribution of bank credit (percent of gross lending) } \\
\hline Households & 60.2 & 64.1 & 63.5 & 62.2 & 56.6 & 49.3 & 49.2 \\
\hline Residential mortgages & 52.0 & 55.6 & 56.1 & 55.2 & 50.8 & 43.6 & 43.1 \\
\hline Non Bank Financial Institutions & 8.2 & 6.4 & 5.7 & 4.2 & 6.8 & 9.3 & 10.1 \\
\hline Property companies & 11.7 & 12.2 & 12.7 & 14.2 & 15.7 & 16.6 & 16.6 \\
\hline Shipping & 1.8 & 1.8 & 1.9 & 1.9 & 2.0 & 3.1 & 3.3 \\
\hline Manufacturing, trade, and services & 8.7 & 7.9 & 7.2 & 7.2 & 7.2 & 8.3 & 7.5 \\
\hline Fishing and fish farming & 2.0 & 1.7 & 1.5 & 1.3 & 1.2 & 1.4 & 1.4 \\
\hline Norwegian public sector (general govt and SOEs) & 0.8 & 0.9 & 1.5 & 1.6 & 1.9 & 1.8 & 1.5 \\
\hline Large exposures as percent of tier 1 capital & 86.8 & 61.5 & 57.0 & 68.0 & 65.0 & 62.0 & \\
\hline of which: Five largest banks & $\cdots$ & $\cdots$ & $\cdots$ & $\cdots$ & $\cdots$ & $\cdots$ & \\
\hline Earnings and profitability $1 /$ & & & & & & & \\
\hline Return on assets (Net income as percent of average total assets) & 0.6 & 0.9 & 1.0 & 0.9 & 0.8 & 0.5 & 0.6 \\
\hline of which: Five largest banks & 0.6 & 0.9 & 1.0 & 1.0 & 0.8 & 0.6 & 0.5 \\
\hline Return on equity (Net income as percent of average equity capital) & 9.6 & 14.9 & 18.4 & 18.4 & 17.0 & 10.7 & 13.3 \\
\hline of which: Five largest banks & 10.6 & 17.6 & 21.1 & 21.6 & 20.0 & 14.8 & 14.0 \\
\hline Net interest income as percent of gross income & 68.4 & 66.5 & 62.9 & 64.5 & 66.1 & 79.0 & 64.2 \\
\hline of which: Five largest banks & 65.0 & 62.9 & 59.2 & 60.6 & 60.8 & 72.8 & 61.1 \\
\hline Noninterest expenses as percent of gross income & 58.7 & 58.2 & 53.7 & 53.6 & 51.4 & 54.5 & 46.6 \\
\hline of which: Five largest banks & 59.2 & 59.3 & 52.3 & 52.4 & 48.0 & 49.0 & 44.0 \\
\hline Noninterest income as percent of total income & 31.6 & 33.5 & 37.1 & 35.5 & 33.9 & 21.0 & 35.8 \\
\hline of which: Five largest banks & 35.0 & 37.1 & 40.8 & 39.4 & 39.2 & 27.2 & 38.9 \\
\hline Trading income and foreign exchange gains (losses) to gross income & 23.9 & 25.8 & 28.7 & 28.0 & 24.4 & 14.3 & 30.5 \\
\hline of which: Five largest banks & 25.7 & 27.9 & 31.5 & 31.3 & 26.2 & 21.7 & 30.9 \\
\hline Personnel expenses as percent of noninterest expenses & 53.2 & 52.0 & 53.3 & 54.8 & 55.1 & 55.9 & 56.5 \\
\hline of which: Five largest banks & 55.3 & 52.2 & 54.9 & 57.1 & 58.0 & 60.1 & 60.9 \\
\hline Liquidity & & & & & & & \\
\hline Liquid assets as percent of total assets & 16.8 & 15.4 & 15.9 & 19.5 & 20.0 & 26.2 & 19.7 \\
\hline of which : Five largest banks & 16.0 & 15.0 & 14.9 & 20.4 & 22.0 & 27.1 & 29.7 \\
\hline Liquid assets as percent of short-term liabilities & 61.5 & 62.2 & 54.8 & 66.6 & 57.9 & 64.5 & 68.8 \\
\hline of which: Five largest banks & 56.9 & 55.8 & 46.3 & 65.9 & 58.0 & 60.8 & 64.7 \\
\hline Customer deposits as a percent of total (non-interbank) loans & 69.3 & 67.6 & 63.8 & 62.3 & 63.0 & 63.1 & 68.0 \\
\hline of which: Five largest banks & 67.9 & 66.3 & 61.8 & 62.0 & 63.9 & 64.0 & 69.8 \\
\hline Noninterbank loans to noninterbank deposits & 144.3 & 147.9 & 156.8 & 160.5 & 158.8 & 158.5 & 147.0 \\
\hline of which: Five largest banks & 147.3 & 150.9 & 161.7 & 161.3 & 156.5 & 156.2 & 143.3 \\
\hline Foreign exchange risk & & & & & & & \\
\hline Foreign currency-denominated loans as percent of total loans & 10.3 & 8.4 & 8.5 & 10.0 & 10.1 & 15.5 & 12.8 \\
\hline Foreign currency-denominated assets as percent of total assets & 14.5 & 11.7 & 12.5 & 17.5 & 16.9 & 25.6 & 21.0 \\
\hline Foreign currency-denominated liabilities as percent of total liabilities & 25.9 & 24.9 & 27.1 & 29.0 & 29.1 & 35.1 & 29.3 \\
\hline Net open position in foreign exchange to regulatory capital 4/ & -152.4 & -174.6 & -196.7 & -166.1 & -190.2 & -162.6 & \\
\hline Exposure to derivatives & & & & & & & \\
\hline Gross asset position in derivatives as percent of tier 1 capital & 49.4 & 31.6 & 37.4 & 36.8 & 57.2 & 94.4 & 56.3 \\
\hline Gross liability position in derivatives as percent of tier 1 capital & 64.3 & 48.1 & 46.8 & 38.0 & 52.9 & 76.0 & 56.5 \\
\hline
\end{tabular}

Sources: Norges Bank; and IMF staff calculations.

1/ For 2009, annualized figures, where applicable for income statement, and end-of-Q3 for balance-sheet.

2/ From 2007, calculation of the capital base and tier I capital follows rules under Basel II.

3/ Does not report performance of asset base of foreign subsidiaries and branches.

4/ Does not include off-balance sheet hedging. 
Table 5. Norway: Financial System Structure, 2000-09

\begin{tabular}{|c|c|c|c|c|c|c|c|c|c|c|c|c|c|c|c|c|}
\hline & & 20 & $\overline{00}$ & & & & 005 & & & 200 & 008 & & & 2009 & & \\
\hline & $\begin{array}{l}\text { Number of } \\
\text { institutions }\end{array}$ & $\begin{array}{l}\text { Total } \\
\text { assets (in } \\
\text { millions of }\end{array}$ & $\begin{array}{l}\text { Percent of } \\
\text { total assets }\end{array}$ & $\begin{array}{l}\text { Percent of } \\
\text { GDP }\end{array}$ & $\begin{array}{l}\text { Number of } \\
\text { institutions }\end{array}$ & $\begin{array}{c}\text { Total } \\
\text { assets (in } \\
\text { millions of }\end{array}$ & $\begin{array}{l}\text { Percent of } \\
\text { total assets }\end{array}$ & $\begin{array}{l}\text { Percent of } \\
\text { GDP }\end{array}$ & $\begin{array}{l}\text { Number of } \\
\text { institutions }\end{array}$ & $\begin{array}{l}\text { Total } \\
\text { assets (in } \\
\text { millions of }\end{array}$ & $\begin{array}{l}\text { Percent of } \\
\text { total assets }\end{array}$ & $\begin{array}{l}\text { Percent of } \\
\text { GDP }\end{array}$ & $\begin{array}{l}\text { Number of } \\
\text { institutions }\end{array}$ & $\begin{array}{c}\begin{array}{c}\text { Total assets } \\
\text { (in millions of } \\
\text { NOK) }\end{array} \\
\end{array}$ & $\begin{array}{l}\text { Percent of } \\
\text { total assets }\end{array}$ & $\begin{array}{l}\text { Percent of } \\
\text { GDP }\end{array}$ \\
\hline \multicolumn{17}{|l|}{$\begin{array}{l}\text { Financial conglomerates } \\
\text { Consolidated basis } 21\end{array}$} \\
\hline \multicolumn{17}{|l|}{$\begin{array}{l}\text { Consolidated basis } 2 / \\
\text { DnB NOR }\end{array}$} \\
\hline Sparebank 1 alliance & & 207,853 & 8.6 & 14.0 & & 323,691 & 8.3 & 16.6 & & 487,553 & 7.6 & 19.2 & & 490,837 & 7.5 & 20.7 \\
\hline Nordea Bank Norge & & 236,184 & 9.8 & 15.9 & & 310,360 & 8.0 & 16.0 & & 549,076 & 8.6 & 21.6 & & 507,567 & 7.8 & 21.4 \\
\hline Fokus Bank & & 48,713 & 2.0 & 3.3 & & 98,412 & 2.5 & 5.1 & & 289,583 & 4.5 & 11.4 & & 195,811 & 3.0 & 8.2 \\
\hline Storebrand & & 113,181 & 4.7 & 7.6 & & 222,758 & 5.7 & 11.4 & & 372,636 & 5.8 & 14.7 & & 368,523 & 5.6 & 15.5 \\
\hline Terra alliance & & 69,228 & 2.9 & 4.7 & & 122,488 & 3.1 & 6.3 & & 178,597 & 2.8 & 7.0 & & 186,785 & 2.9 & 7.9 \\
\hline Total conglomerates & & $1,162,053$ & 48.1 & 78.5 & & $2,036,649$ & 52.3 & 104.7 & & $3,530,547$ & 55.2 & 138.8 & & $3,411,785$ & 52.3 & 143.6 \\
\hline \multicolumn{17}{|l|}{ Institutions in Norway $3 /$} \\
\hline Banks & 152 & $1,331,139$ & 55.1 & 89.9 & 148 & $2,147,138$ & 55.2 & 110.4 & 147 & $3,818,326$ & 59.6 & 150.1 & 150 & $3,707,693$ & 56.8 & 156.1 \\
\hline savings banks & 130 & 559,343 & 23.2 & 37.8 & 126 & $1,409,603$ & 36.2 & 72.4 & 121 & $2,355,948$ & 36.8 & 92.6 & 121 & $2,412,729$ & 37.0 & 101.6 \\
\hline commercial banks & 11 & 623,567 & 25.8 & 42.1 & 8 & 74,590 & 1.9 & 3.8 & 13 & 168,891 & 2.6 & 6.6 & 15 & 178,588 & 2.7 & 7.5 \\
\hline foreign subsidiaries in Norway & 2 & 64,062 & 2.7 & 4.3 & 6 & 434,358 & 11.2 & 22.3 & 3 & 563,185 & 8.8 & 22.1 & 3 & 528,383 & 8.1 & 22.2 \\
\hline foreign branches in Norway & 9 & 84,167 & 3.5 & 5.7 & 8 & 228,587 & 5.9 & 11.7 & 10 & 730,302 & 11.4 & 28.7 & 11 & 587,992 & 9.0 & 24.8 \\
\hline Insurance companies & 68 & 476994 & 19.7 & 32.20 & 57 & 741123 & 19.0 & 38.10 & 56 & 912852 & 14.3 & 35.90 & 57 & 955,570 & 14.6 & 40.2 \\
\hline Mortgage credit institutions & 12 & 211,719 & 8.8 & 14.3 & 13 & 403,980 & 10.4 & 20.8 & 16 & $1,000,591$ & 15.6 & 39.3 & 27 & $1,103,849$ & 16.9 & 46.5 \\
\hline Other credit market companies $4 /$ & 54 & 73,497 & 3.0 & 5.0 & 48 & 125,741 & 3.2 & 6.5 & 51 & 154,706 & 2.4 & 6.1 & 50 & 146,702 & 2.2 & 6.2 \\
\hline \multicolumn{17}{|l|}{$\begin{array}{l}\text { Nonbank financial institutions } \\
\text { Insurance companies }\end{array}$} \\
\hline Life insurance & 15 & 381,493 & 15.8 & 25.8 & 11 & 609,804 & 15.7 & 31.3 & 10 & 739,744 & 11.6 & 29.1 & 12 & 776,418 & 11.9 & 32.7 \\
\hline Nonlife insurance $5 /$ & 53 & 95,501 & 4.0 & 6.4 & 46 & 131,320 & 3.4 & 6.7 & 46 & 173,108 & 2.7 & 6.8 & 45 & 179,152 & 2.7 & 7.5 \\
\hline Mutual funds $6 / 71$ & 380 & 142,223 & 5.9 & 9.6 & 467 & 273865 & 7.0 & 14.1 & 582 & 291,784 & 4.6 & 11.5 & 568 & 382,185 & 5.9 & 16.1 \\
\hline Other nonbank credit institutions $8 /$ & 3 & 179,884 & 7.4 & 12.1 & 3 & 200,897 & 5.2 & 10.3 & 3 & 223,043 & 3.5 & 8.8 & 3 & 232,409 & 3.6 & 9.8 \\
\hline \multirow{2}{*}{\multicolumn{17}{|c|}{$\begin{array}{l}\text { Memorandum item: } \\
\text { Nominal GDP (in millions of NOK) }\end{array}$}} \\
\hline & & $1,481,241$ & & & & $1,945,715$ & & & & $2,543,188$ & & & & $2,375,316$ & & \\
\hline Total financial system 9/ & 669 & $2,415,455$ & 100.0 & 163.10 & 736 & $3,892,744$ & 100.0 & 200.10 & 855 & $6,401,303$ & 100.0 & 251.70 & 855 & $6,528,409$ & 100.0 & 274.8 \\
\hline
\end{tabular}

$1 /$ As of end-September 2009.

For

$5 /$ Excluding minor loca

6/ Market value of funds.

8/ State lending institutions.

9/ Number of institutions on an unconsolidated basis; only the parent banks in the DnB NOR, Nordea, and Storebrand groups are included in the calculation of the asset base. 
Table 6. Norway: Key Fiscal Indicators, 2004-10

(Percent of mainland GDP, unless otherwise indicated)

\begin{tabular}{|c|c|c|c|c|c|c|c|}
\hline & \multirow[b]{2}{*}{2004} & \multirow[b]{2}{*}{2005} & \multirow[b]{2}{*}{2006} & \multirow[b]{2}{*}{2007} & \multirow[b]{2}{*}{2008} & \multicolumn{2}{|c|}{ Proj. } \\
\hline & & & & & & 2009 & 2010 \\
\hline \multicolumn{8}{|l|}{ Central Government 1/ } \\
\hline Revenue & 55.1 & 59.3 & 62.9 & 59.7 & 65.1 & 55.2 & 50.5 \\
\hline Oil revenue & 16.4 & 20.5 & 23.8 & 19.6 & 24.1 & 15.7 & 12.7 \\
\hline Nonoil revenue & 38.7 & 38.9 & 39.1 & 40.2 & 41.0 & 39.5 & 37.8 \\
\hline Expenditure & 45.9 & 44.8 & 43.2 & 41.5 & 42.8 & 47.3 & 47.1 \\
\hline of which: oil expenditure & 1.4 & 1.5 & 1.3 & 1.2 & 1.2 & 1.4 & 1.3 \\
\hline Balance & 9.2 & 14.5 & 19.7 & 18.3 & 22.2 & 7.9 & 3.5 \\
\hline $\begin{array}{l}\text { Nonoil balance } \\
\text { less adjustments: }\end{array}$ & -5.8 & -4.5 & -2.8 & -0.1 & -0.6 & -6.4 & -8.0 \\
\hline Extraordinary items 2/ & 0.2 & 0.2 & 0.4 & 0.2 & 0.0 & -0.4 & 0.0 \\
\hline Cyclical correction 3/ & -2.8 & -1.3 & 0.2 & 3.0 & 3.3 & 1.0 & -0.2 \\
\hline Structural nonoil balance & -3.3 & -3.4 & -3.3 & -3.3 & -4.0 & -7.0 & -7.7 \\
\hline In percent of Pension Fund Global capital 4/ & -5.2 & -4.8 & -3.8 & -3.2 & -3.6 & -5.7 & -5.7 \\
\hline In percent of trend mainland GDP 5/ & -3.2 & -3.4 & -3.4 & -3.5 & -4.2 & -7.2 & -7.8 \\
\hline Fiscal impulse (percent of trend mainland GDP) 5/ & 0.3 & 0.2 & 0.0 & 0.1 & 0.7 & 3.0 & 0.6 \\
\hline \multicolumn{8}{|l|}{ General Government 6/ } \\
\hline Revenue & 69.2 & 73.1 & 77.2 & 74.1 & 78.8 & 65.6 & 64.8 \\
\hline Oil revenue & 19.1 & 23.5 & 26.9 & 23.3 & 28.7 & 17.6 & 17.0 \\
\hline Nonoil revenue & 50.0 & 49.6 & 50.2 & 50.8 & 50.1 & 48.1 & 47.8 \\
\hline Expenditure & 54.8 & 52.9 & 51.9 & 50.7 & 52.7 & 56.3 & 56.7 \\
\hline of which: oil expenditure & 0.1 & 0.1 & 0.1 & 0.1 & 0.1 & 0.1 & 0.1 \\
\hline Balance & 14.3 & 20.2 & 25.3 & 23.4 & 26.1 & 9.4 & 8.2 \\
\hline Nonoil balance & -4.7 & -3.2 & -1.6 & 0.2 & -2.5 & -8.1 & -8.8 \\
\hline Gross debt & 67.8 & 65.8 & 82.7 & 77.1 & 78.5 & 94.8 & 91.1 \\
\hline Net financial assets & 134.3 & 164.1 & 186.3 & 187.8 & 174.6 & 188.4 & 192.8 \\
\hline of which: Pension Fund Global capital & 74.6 & 95.8 & 112.8 & 117.1 & 125.4 & 140.1 & 146.4 \\
\hline
\end{tabular}

Sources: Ministry of Finance; Statistics Norway; Norges Bank; and IMF staff estimates.

1/ Budget definition; excludes Pension Fund Global. Projections are based on the draft 2010 budget, published October 13, 2009

2/ Includes exceptional transactions with local government and accounting discrepancies.

3/ Estimated by Ministry of Finance. Includes cyclical adjustments for transfers from Norges Bank and net interest income.

4/ Key policy indicator under Norway's fiscal guidelines, which set an over-the-cycle target for the structural nonoil deficit of 4 percent.

5/ Trend output as estimated by the Ministry of Finance.

6/ National accounts definition. In addition to central government, includes also Government Pension Fund, other social security and central government accounts, state enterprises, and local government. Projections are based on the draft 2010 budget. 
Table 7. Norway: General Government Accounts, 2004-10

\begin{tabular}{|c|c|c|c|c|c|c|c|}
\hline & \multirow[b]{2}{*}{2004} & \multirow[b]{2}{*}{2005} & \multirow[b]{2}{*}{2006} & \multirow[b]{2}{*}{2007} & \multirow[b]{2}{*}{2008} & \multicolumn{2}{|c|}{ Proj. 1/ } \\
\hline & & & & & & 2009 & 2010 \\
\hline \multicolumn{8}{|l|}{ (Billions of NOK) } \\
\hline Total revenue & 937.3 & $1,061.5$ & $1,219.7$ & $1,278.1$ & $1,432.4$ & $1,216.6$ & $1,250.1$ \\
\hline Oil revenue & 259.0 & 341.4 & 425.9 & 401.8 & 521.6 & 325.7 & 328.5 \\
\hline of which: investment income on the GPF-Global & 33.3 & 36.9 & 55.7 & 74.3 & 97.8 & 103.5 & 100.7 \\
\hline Nonoil revenue & 678.3 & 720.1 & 793.9 & 876.3 & 910.8 & 890.9 & 921.6 \\
\hline Financial income & 51.4 & 53.4 & 60.3 & 68.4 & 78.4 & 67.2 & 63.0 \\
\hline Tax revenue & 617.1 & 656.4 & 722.8 & 796.5 & 817.9 & 812.2 & 846.2 \\
\hline Other current revenue & 8.6 & 9.4 & 9.1 & 10.3 & 10.4 & 10.7 & 11.0 \\
\hline Capital revenue & 1.7 & 1.8 & 2.1 & 2.6 & 2.0 & 2.2 & 1.4 \\
\hline Total expenditure & 743.2 & 767.9 & 820.6 & 874.3 & 957.4 & $1,042.9$ & $1,092.8$ \\
\hline of which: oil expenditure & 1.2 & 0.7 & 1.2 & 1.1 & 1.8 & 1.1 & 1.4 \\
\hline Interest expenditure & 24.6 & 23.5 & 33.1 & 29.8 & 36.4 & 31.7 & 31.6 \\
\hline Transfers & 326.7 & 337.6 & 348.8 & 366.9 & 395.0 & 430.7 & 458.0 \\
\hline Final consumption & 340.9 & 353.1 & 376.2 & 406.6 & 445.9 & 488.4 & 513.1 \\
\hline Capital expenditure (gross) & 51.0 & 53.8 & 62.5 & 71.0 & 80.2 & 92.0 & 90.2 \\
\hline Capital expenditure (net) & 18.7 & 19.6 & 25.8 & 30.4 & 35.8 & 44.3 & 41.8 \\
\hline Overall balance & 194.1 & 293.5 & 399.1 & 403.9 & 475.0 & 173.8 & 157.3 \\
\hline Nonoil balance 2/ & -63.6 & -47.1 & -25.5 & 3.1 & -44.8 & -150.8 & -169.8 \\
\hline \multicolumn{8}{|l|}{ (Percent of mainland GDP) } \\
\hline Total revenue & 69.2 & 73.1 & 77.2 & 74.1 & 78.8 & 65.6 & 64.8 \\
\hline Oil revenue & 19.1 & 23.5 & 26.9 & 23.3 & 28.7 & 17.6 & 17.0 \\
\hline of which: return on the GPF-Global & 2.5 & 2.5 & 3.5 & 4.3 & 5.4 & 5.6 & 5.2 \\
\hline Nonoil revenue & 50.0 & 49.6 & 50.2 & 50.8 & 50.1 & 48.1 & 47.8 \\
\hline Financial income & 3.8 & 3.7 & 3.8 & 4.0 & 4.3 & 3.6 & 3.3 \\
\hline Tax revenue & 45.5 & 45.2 & 45.7 & 46.2 & 45.0 & 43.8 & 43.9 \\
\hline Other current revenue & 0.6 & 0.6 & 0.6 & 0.6 & 0.6 & 0.6 & 0.6 \\
\hline Capital revenue & 0.1 & 0.1 & 0.1 & 0.1 & 0.1 & 0.1 & 0.1 \\
\hline Total expenditure & 54.8 & 52.9 & 51.9 & 50.7 & 52.7 & 56.3 & 56.7 \\
\hline of which: oil expenditure & 0.1 & 0.1 & 0.1 & 0.1 & 0.1 & 0.1 & 0.1 \\
\hline Interest expenditure & 1.8 & 1.6 & 2.1 & 1.7 & 2.0 & 1.7 & 1.6 \\
\hline Transfers & 24.1 & 23.3 & 22.1 & 21.3 & 21.7 & 23.2 & 23.7 \\
\hline Final consumption & 25.2 & 24.3 & 23.8 & 23.6 & 24.5 & 26.3 & 26.6 \\
\hline Capital expenditure (gross) & 3.8 & 3.7 & 4.0 & 4.1 & 4.4 & 5.0 & 4.7 \\
\hline Capital expenditure (net) & 1.4 & 1.4 & 1.6 & 1.8 & 2.0 & 2.4 & 2.2 \\
\hline Overall balance & 14.3 & 20.2 & 25.3 & 23.4 & 26.1 & 9.4 & 8.2 \\
\hline Nonoil balance $2 /$ & -4.7 & -3.2 & -1.6 & 0.2 & -2.5 & -8.1 & -8.8 \\
\hline \multicolumn{8}{|l|}{ Memorandum items: } \\
\hline \multicolumn{8}{|l|}{ General government gross debt } \\
\hline Billions of NOK & 1,374 & 1,454 & 1,537 & 1,625 & 1,715 & 1,808 & 1,904 \\
\hline Percent of GDP & 78.9 & 74.7 & 71.2 & 71.5 & 67.4 & 76.1 & 75.4 \\
\hline \multicolumn{8}{|l|}{ General government net assets } \\
\hline Billions of NOK & 1,820 & 2,381 & 2,944 & 3,238 & 3,174 & 3,492 & 3,718 \\
\hline Percent of GDP & 104.4 & 122.4 & 136.3 & 142.5 & 124.8 & 147.0 & 147.2 \\
\hline Nominal GDP (billions of NOK) & 1,743 & 1,946 & 2,160 & 2,272 & 2,543 & 2,375 & 2,526 \\
\hline Nominal mainland GDP (billions of NOK) & 1,355 & 1,451 & 1,581 & 1,724 & 1,818 & 1,854 & 1,928 \\
\hline Mainland output gap (IMF staff estimates and projections) & -1.9 & -0.6 & 1.0 & 3.5 & 3.1 & -0.3 & -0.1 \\
\hline
\end{tabular}

Sources: Ministry of Finance; Statistics Norway; and IMF staff estimates.

1/ Fiscal projections are based on the draft 2010 budget, published October 13, 2009.

2/ Also excludes the return on the GPF-Global. 
Table 8. Norway: External Indicators, 2005-14

\begin{tabular}{|c|c|c|c|c|c|c|c|c|c|c|}
\hline & & & & & \multicolumn{6}{|c|}{ Projections $1 /$} \\
\hline & 2005 & 2006 & 2007 & 2008 & 2009 & 2010 & 2011 & 2012 & 2013 & 2014 \\
\hline & \multicolumn{10}{|c|}{ (Billions of USD) } \\
\hline Current account balance & 49.1 & 58.0 & 54.7 & 83.8 & 52.0 & 64.0 & 64.0 & 63.6 & 64.8 & 64.5 \\
\hline Balance of goods and services & 49.7 & 60.8 & 59.4 & 86.4 & 48.6 & 61.8 & 63.1 & 63.4 & 64.3 & 64.7 \\
\hline Trade balance & 46.8 & 55.9 & 53.1 & 79.2 & 44.4 & 57.1 & 58.5 & 58.7 & 59.4 & 59.6 \\
\hline Trade balance (goods excl. oil and nat. gas) & -19.7 & -21.8 & -28.7 & -30.9 & -23.4 & -25.5 & -26.9 & -28.3 & -29.6 & -31.1 \\
\hline Services balance & 3.0 & 4.9 & 6.3 & 7.2 & 4.2 & 4.7 & 4.6 & 4.7 & 4.9 & 5.1 \\
\hline Exports & 134.8 & 156.3 & 177.4 & 216.8 & 151.1 & 170.5 & 175.9 & 180.5 & 185.9 & 191.2 \\
\hline Goods & 103.7 & 122.0 & 135.7 & 169.8 & 113.7 & 131.1 & 135.3 & 138.5 & 142.4 & 146.1 \\
\hline o/w: oil and natural gas & 66.4 & 77.7 & 81.9 & 110.0 & 67.8 & 82.6 & 85.4 & 87.0 & 88.9 & 90.6 \\
\hline Non-factor services & 31.0 & 34.3 & 41.7 & 47.0 & 37.4 & 39.4 & 40.6 & 42.0 & 43.5 & 45.1 \\
\hline Imports & 85.1 & 95.5 & 118.0 & 130.4 & 102.4 & 108.7 & 112.8 & 117.2 & 121.6 & 126.5 \\
\hline Goods & 57.0 & 66.2 & 82.5 & 90.6 & 69.3 & 74.0 & 76.8 & 79.9 & 83.0 & 86.5 \\
\hline Non-factor services & 28.1 & 29.4 & 35.5 & 39.8 & 33.2 & 34.8 & 36.0 & 37.3 & 38.6 & 40.0 \\
\hline Balance on income and transfers & -0.6 & -2.7 & -4.7 & -2.6 & 3.4 & 2.2 & 0.9 & 0.2 & 0.5 & -0.2 \\
\hline Capital account balance & -0.3 & -0.1 & -0.2 & -0.2 & -0.2 & -0.2 & -0.2 & -0.2 & -0.2 & -0.2 \\
\hline Financial account balance & -38.7 & -40.1 & -25.0 & -77.6 & -65.8 & -59.9 & -59.9 & -59.6 & -60.9 & -60.7 \\
\hline Net errors and omissions & -5.7 & -12.4 & -28.1 & 1.5 & 0.0 & 0.0 & 0.0 & 0.0 & 0.0 & 0.0 \\
\hline \multirow[t]{2}{*}{ Change in reserves (- $=$ increase) } & -4.4 & -5.4 & -1.5 & -7.6 & 14.0 & -4.0 & -3.9 & -3.8 & -3.8 & -3.7 \\
\hline & \multicolumn{10}{|c|}{ (Percent of mainland GDP) } \\
\hline Current account balance & 21.8 & 23.5 & 18.6 & 26.0 & 18.7 & 21.7 & 21.1 & 20.3 & 20.1 & 19.4 \\
\hline Balance of goods and services & 22.1 & 24.7 & 20.2 & 26.8 & 17.5 & 20.9 & 20.8 & 20.3 & 19.9 & 19.4 \\
\hline Trade balance (goods) & 20.8 & 22.7 & 18.1 & 24.6 & 16.0 & 19.3 & 19.3 & 18.8 & 18.4 & 17.9 \\
\hline Trade balance (goods excl. oil and nat. gas) & -8.7 & -8.9 & -9.8 & -9.6 & -8.4 & -8.6 & -8.9 & -9.0 & -9.2 & -9.3 \\
\hline Services balance & 1.3 & 2.0 & 2.1 & 2.2 & 1.5 & 1.6 & 1.5 & 1.5 & 1.5 & 1.5 \\
\hline Exports & 59.8 & 63.4 & 60.3 & 67.2 & 54.3 & 57.7 & 58.0 & 57.7 & 57.6 & 57.5 \\
\hline Goods & 46.1 & 49.5 & 46.1 & 52.7 & 40.9 & 44.3 & 44.6 & 44.3 & 44.1 & 43.9 \\
\hline o/w: oil and natural gas & 29.5 & 31.5 & 27.8 & 34.1 & 24.4 & 28.0 & 28.2 & 27.8 & 27.6 & 27.2 \\
\hline Non-factor services & 13.8 & 13.9 & 14.2 & 14.6 & 13.4 & 13.3 & 13.4 & 13.4 & 13.5 & 13.6 \\
\hline Imports & 37.8 & 38.8 & 40.1 & 40.4 & 36.8 & 36.8 & 37.2 & 37.5 & 37.7 & 38.0 \\
\hline Goods & 25.3 & 26.8 & 28.0 & 28.1 & 24.9 & 25.0 & 25.3 & 25.5 & 25.7 & 26.0 \\
\hline Non-factor services & 12.5 & 11.9 & 12.1 & 12.3 & 11.9 & 11.8 & 11.9 & 11.9 & 12.0 & 12.0 \\
\hline Balance on income and transfers & -0.3 & -1.1 & -1.6 & -0.8 & 1.2 & 0.7 & 0.3 & 0.1 & 0.2 & 0.0 \\
\hline Capital account balance & -0.1 & -0.1 & -0.1 & -0.1 & -0.1 & -0.1 & -0.1 & -0.1 & -0.1 & -0.1 \\
\hline Financial account balance & -17.2 & -16.3 & -8.5 & -24.1 & -23.6 & -20.3 & -19.8 & -19.1 & -18.9 & -18.2 \\
\hline Net errors and omissions & -2.5 & -5.0 & -9.5 & 0.5 & 0.0 & 0.0 & 0.0 & 0.0 & 0.0 & 0.0 \\
\hline Change in reserves $(-=$ increase $)$ & -2.0 & -2.2 & -0.5 & -2.4 & 5.0 & -1.3 & -1.3 & -1.2 & -1.2 & -1.1 \\
\hline Stock of net foreign assets & 77.4 & 80.7 & 71.0 & 91.0 & $\ldots$ & $\ldots$ & $\ldots$ & $\ldots$ & $\ldots$ & $\ldots$ \\
\hline Direct investment & 6.7 & 8.3 & 7.1 & 13.6 & $\ldots$ & $\ldots$ & $\ldots$ & $\ldots$ & $\ldots$ & $\ldots$ \\
\hline Portfolio investment & 57.1 & 77.6 & 69.8 & 106.8 & $\ldots$ & $\ldots$ & $\ldots$ & $\ldots$ & $\ldots$ & $\ldots$ \\
\hline Other investment & -8.4 & -27.5 & -25.1 & -52.3 & $\ldots$ & $\ldots$ & $\ldots$ & $\ldots$ & $\ldots$ & $\ldots$ \\
\hline Official reserves & 22.0 & 22.4 & 19.2 & 22.9 & $\ldots$ & $\ldots$ & $\ldots$ & $\ldots$ & $\ldots$ & $\ldots$ \\
\hline \multicolumn{11}{|l|}{ Government Pension Fund - Global } \\
\hline Based on 2010 National Budget assumptions & 95.8 & 112.8 & 117.1 & 125.4 & 144.7 & 151.9 & $\ldots$ & $\ldots$ & $\ldots$ & $\ldots$ \\
\hline Nominal effective exchange rate $(2000=100)$ & 111.8 & 111.5 & 114.3 & 115.1 & $\ldots$ & $\ldots$ & $\ldots$ & $\ldots$ & $\ldots$ & $\ldots$ \\
\hline Real effective exchange rate $(2000=100) 2 /$ & 111.2 & 111.3 & 112.3 & 113.4 & $\ldots$ & $\ldots$ & $\ldots$ & $\ldots$ & $\ldots$ & $\ldots$ \\
\hline Terms of Trade (annual percent change) & 15.6 & 11.9 & -1.6 & 12.2 & $\ldots$ & $\ldots$ & $\ldots$ & $\ldots$ & $\ldots$ & $\ldots$ \\
\hline
\end{tabular}

Sources: Statistics Norway; Ministry of Finance; and IMF staff estimates.

1/ IMF staff projections as of December 2009.

2/ Based on CPI. 


\section{ANNEX I. AUTHORITIES' RESPONSE TO THE CRISIS ${ }^{10}$}

\section{Macroeconomic policies}

- Between October 2008 and June 2009, Norges Bank cut the policy rate by 450 basis points to 1.25 percent.

- The revised 2009 Budget programs discretionary fiscal stimulus equivalent to 3 percent of mainland GDP. An additional 0.6 percent of mainland GDP is foreseen in the 2010 budget.

\section{Measures to shore up banks' NOK liquidity position}

- In October 2008, Norges Bank eased collateral requirements — by waiving requirements related to minimum credit ratings, listing on an exchange, and minimum volumes outstanding - to increase banks' access to its liquidity facilities. In October 2009, Norges Bank announced its intention to reverse these changes in the near future.

- In order to ease banks' funding operations, the authorities created a NOK 350 billion bond swap program under which banks could obtain government securities in exchange for covered bonds. The securities could be sold, used as collateral for obtaining funding, or just kept to strengthen the balance sheet of the banks. The program was phased out in December 2009, with a total utilization of NOK 230 billion.

- In order to ease liquidity conditions for small banks, Norges Bank established a longer-term F-Loan program, with maturities up to three years. The last such auction took place in February 2009.

- Norges Bank temporarily provided NOK liquidity through cross-currency swaps.

- The Norwegian government granted a special deposit guarantee to depositors in the Norwegian branch of Kaupthing Bank up to the amount guaranteed by the Icelandic deposit guarantee scheme. In the event, Kaupthing's Norwegian assets were sufficient to cover all liabilities.

\section{Measures to reduce stress in US\$ funding markets}

- Backed by a swap agreement with the U.S. Federal Reserve, Norges Bank provided banks with US\$ liquidity through cross-currency swaps and term loans (with maturity of 84 days). The program was discontinued in October 2009.

\section{Measures to strengthen banks' capital and avert a credit crunch}

In March 2009, the government set up the State Finance Fund to provide core capital support of up to NOK 50 billion to banks. The public capital injection takes the form of Tier I preference shares or hybrid Tier I capital. 34 banks applied for a total of NOK 6.7 billion from the Fund by the September 30 deadline. The capital injections are scheduled to be finalized by January 15, 2010.

\footnotetext{
${ }^{10}$ Prepared by Andre Meier and Jay Surti.
} 
- In March 2009, the government also created the Government Bond Fund in order to address illiquidity in the domestic corporate bond market. The Fund is buying corporate bonds in the primary and secondary markets up to a maximum amount of NOK 50 billion. As of August 17, the Fund had invested NOK 6.2 billion.

- The government increased the export guarantee scheme of the central government export guarantee agency (GIEK) by NOK 50 billion. It also extended a loan agreement for NOK 50 billion to Eksportfinans (semi-private export finance institution) to support the extension of CIRR-loans.

\section{Measures to curb disruptive market speculation}

A ban on short-selling of bank and insurance sector shares was imposed in October 2008 in order to prevent excess market volatility. The ban was lifted in September 2009. 


\section{Annex II. Collapse Then—Calm Today: What Has Changed Since The 1988-93 BANKING CRISIS? ${ }^{11}$}

Norway's banking system suffered a protracted crisis during 1988-93, which at its peak led to the nationalization of three large banks. Recent years have seen a credit and asset price boom reminiscent of developments leading up to that earlier crisis. Why then has Norway fared so much better during the latest global financial turmoil? This annex highlights improvements in risk management and prudential standards, yet the key difference is a more flexible and responsive macroeconomic framework. Even so, the banking system faces important vulnerabilities today, underscoring the need for policymakers to remain vigilant and heed the lessons from past crises.

Mounting losses on bad loans pushed Norway's banking system into financial crisis two decades ago. The crisis started with an economic slowdown amid sharply falling real estate prices in 1988. It initially affected only smaller banks, whose failures could be handled by the existing private bank guarantee funds. Over time, however, larger banks also came under pressure, especially from their sizeable exposures to commercial real estate. By the fall of 1991, the rate of bad loans had risen to 9 percent, and the country's three largest commercial banks - accounting for more than half of total lending - had effectively depleted most or all of their equity capital. In its rescue operation, the government wiped out private shareholders (though none of the creditors, including those with subordinated claims), and recapitalized the banks under public ownership. Loan losses continued to rise for another year, and more public capital was injected in 1992, but conditions started gradually improving from there.

The crisis followed several years of a credit-fuelled asset boom in a newly deregulated market. In 1984, the authorities started to phase out long-standing regulations that had put limits on credit growth. Large pent-up loan demand subsequently coincided with strong competition among banks and low real interest rates, driving real credit growth up above 20 percent. The credit boom fueled, and was in turn reinforced by, a surge in real estate prices, especially for commercial property. Yet, banks were conducting their expansion from a limited capital base, including strong reliance on subordinated debt instruments. At the same time, supervisory standards were lagging behind, reflecting the long history of a relatively safe and sheltered banking system. Indeed, on-site supervision had been all but abandoned in favor of off-site monitoring by the mid-1980s.

\section{Norway's most recent credit and asset price boom bears some parallels with trends in the mid-1980s, but the banking system has avoided a solvency crisis this time. Residential house prices rose by a cumulative 50 percent in real terms from end-2003 through end-2007, underpinned by real credit growth on the same order of magnitude. As a result, household debt reached 190 percent of disposable income by end-2007, one of the highest ratios among OECD countries. Although data on commercial real estate are more limited, there are clear indications that the boom in this market was even stronger. The trend}

\footnotetext{
${ }^{11}$ Prepared by Andre Meier and Jay Surti.
} 
only turned when successive interest rate hikes and a weaker economy significantly cooled demand in late 2007, prompting a correction in prices (if only short-lived in the case of the residential market). Still, banks have not faced any significant asset quality problems during the current downturn, and have maintained capital adequacy even as many of their peers in other advanced economies suffered severe solvency risks.

The system's resilience today is partly due to lessons learnt from the previous crisis. On the regulatory side, the crisis of the early 1990s ushered in a period of relative conservatism. Although generally following Basle and European Union standards, the Norwegian authorities imposed slightly tighter constraints on domestic banks in some areas. They have limited, for example, banks' freedom to count subordinated debt toward their capital requirements, ensuring better average quality of bank capital. In addition, the FSA has maintained a strong emphasis on capital buffers above minimum requirements, while practicing a conservative approach to the approval of IRB models. Similarly, the authorities have taken a restrictive approach on securitization, effectively precluding any issuance of products other than covered bonds. The greater conservatism on the regulator's side may have been matched by a relatively cautious practice in banks, as at least some of the risk managers in charge today still have personal memories of the previous crisis. Thus, Norwegian banks did not have, for instance, any significant exposure to the toxic foreign securities which triggered the global financial crisis. Corporate borrowers, in turn, have generally maintained higher equity ratios than during the 1980s, providing a buffer for adverse shocks and limiting loan losses during the downturn.

However, some of the earlier tightening of prudential standards and risk management practices has been partially reversed in recent years. Although the Norwegian authorities adopted a particularly conservative approach following Norway's financial crisis of 1988-93, some of this extra conservatism may have gradually worn off again under pressure from regulatory competition associated with foreign bank branches operating in Norway. A relevant example is the FSA's decision in 2001 to reverse an earlier tightening of restrictions on subordinated debt. Around the same time, the FSA also raised the maximum loan-to-value ratio for loans with a 50 percent capital risk weight. On the banks' side, recent years have seen a boom in more risky lending practices, including mortgages with loan-to-value ratios of 100 percent or more. Many banks also feature quite large exposures to certain vulnerable sectors, notably shipping.

Indeed, changes in the macroeconomic policy framework are likely to have been a more important reason for the benign outcome in $\mathbf{2 0 0 8 / 0 9}$. At the time of the domestic financial crisis 20 years ago, macroeconomic policy was in the straitjacket of an exchange rate peg (against the ECU) that provided no room for monetary easing as the economy slid into recession. In fact, the subsequent rise in German policy rates (to moderate the boom associated with reunification) imposed a strongly procyclical tightening on the Norwegian economy at the height of the crisis. Fiscal policy also turned expansionary only in the later stages of the crisis. This experience contrasts markedly with the swift policy response since late 2008, which has combined large fiscal stimulus with significant policy rate cuts. 
The strongly expansionary policy response in 2008/09 kept Norway's recession shallow, effectively averting a real stress test of the financial sector. Given the nature of the residential mortgage market with full-recourse loans at variable interest rates, significant default rates are very unlikely as long as both unemployment and interest rates stay low. Commercial real estate markets, in turn, also derive a strong boost from robust domestic demand and low policy rates, even though the share of fixed-rate loans in this market is somewhat higher. Accordingly, it is not very surprising that banks have faced limited asset quality problems thus far. Without downplaying the direct contribution from sound risk management and regulation, it seems fair to state that the Norwegian banking system simply has not been put to a very harsh macroeconomic stress test this time.

\section{In conclusion, sound prudential standards and a strong macroeconomic policy} framework represent significant advances, but challenges remain. Despite the greater resilience of the system, banks are vulnerable to credit risk from their exposures to commercial real estate and certain cyclically-weak sectors, notably shipping. Moreover, households' high debt levels could work as an amplifier of any adverse macroeconomic shock. Indeed, such systemic vulnerabilities may be increasing further to the extent that the current low interest rates induce borrowers to ramp up, rather than reduce, their indebtedness. The swift turnaround in residential house prices, which are now slightly above their mid2007 peak, is one warning sign in this regard.

This underscores the need for policymakers to remain vigilant and proactive, including in the area of macroprudential regulation. Efforts to preserve financial stability should concentrate, first, on finding appropriate tools to avoid excessive price and debt dynamics in the housing market. Monetary policy should take such risks into account, given their potential to affect future macroeconomic outcomes, but the policy rate alone is not a perfect instrument. For one thing, tail risks to the inflation outlook (as implied by asset price/credit booms) will not always guide monetary policy in the same direction as the baseline inflation outlook. There is, consequently, a case for adopting other tools, including macroprudential regulation or tax policy measures, to try and engineer a soft landing in the real estate market. In addition, policymakers will need to maintain high standards of microprudential regulation and supervision, with continued emphasis on on-site supervisory work and close contact with top management. Staying vigilant obviously poses a challenge the more memories of Norway's financial crisis in the early 1990s recede. However, the experience of global financial turmoil in recent months surely serves to recall the importance of the task.

\section{$\underline{\text { Sources: }}$}

Berg, Sigbjørn A. and Øyvind Eitrheim (2009): Bank Regulation and Bank Crisis: The main developments in the Norwegian regulatory system before, during and after the banking crisis of 1988-92. Norges Bank Working Paper No. 18/2009.

Moe, Thorvald G., Jon A. Solheim, and Bent Vale, eds. (2004): The Norwegian Banking Crisis. Norges Bank Occasional Paper No. 33. 


\section{ANNEX III. SPILlOVERS FroM THE EURO AREA TO NORWAY-THE Role OF FinANCIAL SHOCKS ${ }^{12}$}

\section{This annex analyzes spillovers from the euro area to Norway through financial and} trade channels. Norway has strong trade and financial linkages with the euro area:

- $\quad$ Norway's banks rely heavily on foreign wholesale financing.

- $\quad$ Foreigners hold more than 60 percent of all outstanding debt securities and a significant share of domestic equities.

- $\quad$ The euro area's share in Norway's non-oil exports is about 40 percent (with another 20 percent going to other European economies). Practically all Norwegian energy exports are destined to Europe, with nearly half going to euro area economies. Import shares have a similar geographic profile.
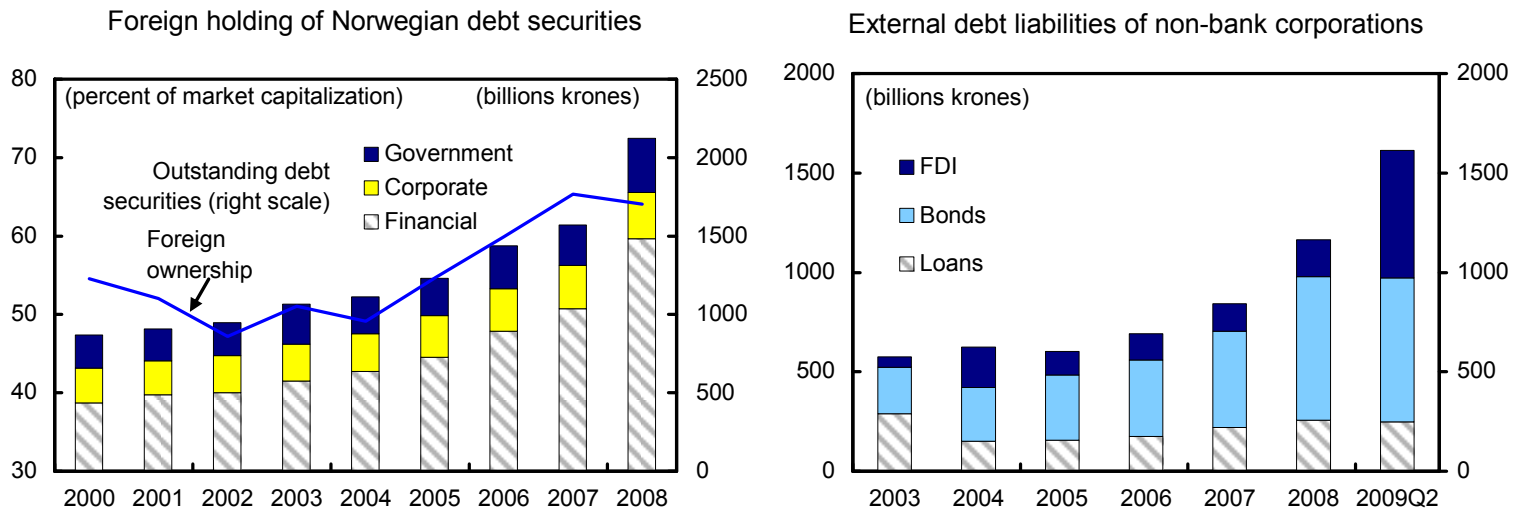

Sources: Bank for International Settlements; Haver Analytics; Statistics Norway; and IMF staff calculations.

The analysis is based on a structural VAR model. The model includes four variables: euro area and Norway's mainland real GDP growth, oil price growth, and a measure of financial stress for the euro area. ${ }^{13}$ The financial stress index relies on price movements relative to past levels or trend to proxy for the presence of strains in financial markets or on intermediation. ${ }^{14}$ The index is constructed so that a value of zero implies neutral financial market conditions, while positive values indicate

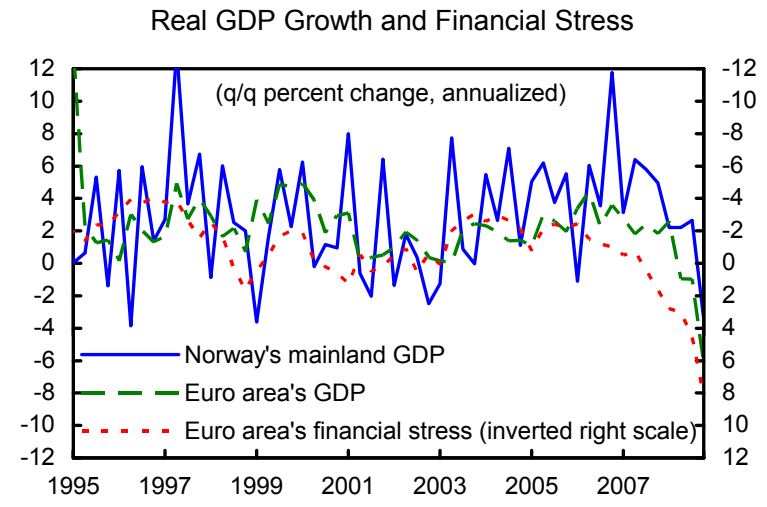

12 Prepared by Volodymyr Tulin.

${ }^{13}$ Variables for the euro area and the oil price are assumed to be exogenous with respect to Norwegian variables. The data cover the period 1991Q1-2007Q4 at a quarterly frequency. The results are robust to the inclusion of additional variables, such as inflation, the real exchange rate and domestic financial stress.

${ }^{14}$ For details of the construction, see IMF WP 09/133 by R. Balakrishnan, S. Danninger, S. Elekdag, and I. Tytell: "The transmission of financial stress from advanced to emerging economies". 
financial strain. One unit of the index is equivalent to one standard deviation from average conditions.

The results suggest that external financial shocks have a significant effect on Norway's growth. A one unit shock to the euro area's financial stress index reduces Norway's mainland GDP growth by about 0.5 percentage points in three quarters. The final chart presents a decomposition of the financial shock impact into financial and trade channels. The trade channel is proxied by the effect of the change in euro area growth caused by the financial shock on Norway's growth. The financial channel is the direct effect of the financial shock on Norway's growth (excluding the indirect effect working through the change in euro area growth and export demand). One can think of the latter as Norwegian banks and corporations facing adverse financing conditions. The decomposition suggests that external financial stress is transmitted predominantly through financial channels.
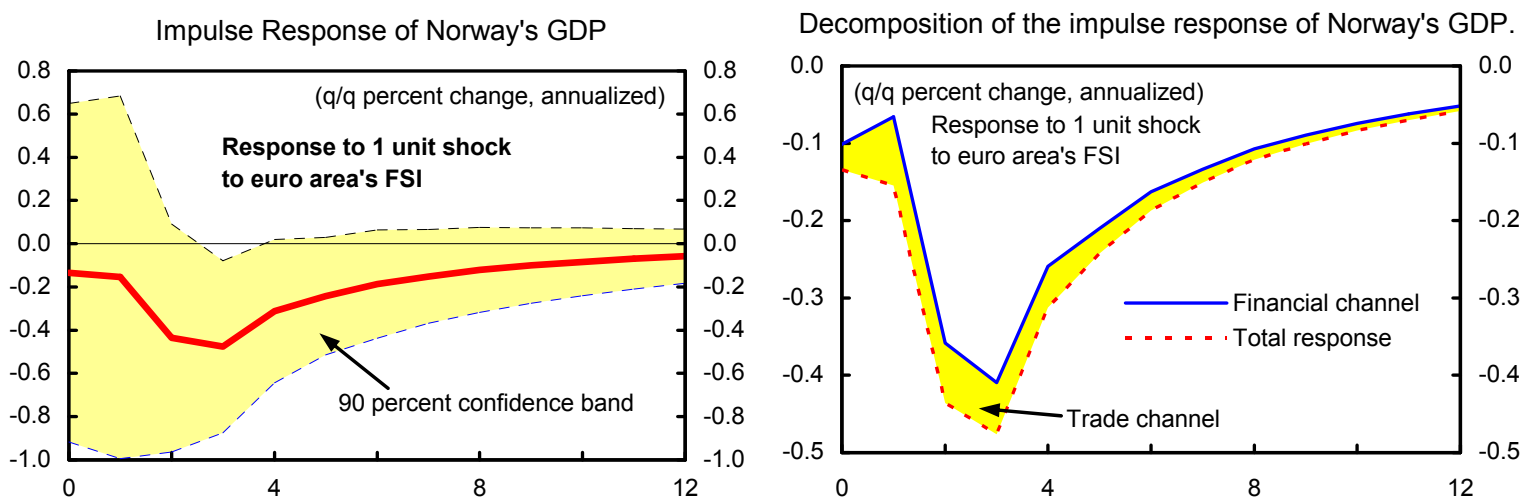

Despite the historically strong influence of external financial conditions on the domestic economy, Norway has weathered the global financial crisis very well. This underscores the effectiveness of the substantial macroeconomic stimulus and measures taken to ameliorate domestic financial strains. 


\section{Annex IV. Recent Stress Tests of Norwegian Banks' Portfolios ${ }^{1}$}

\section{Norges Bank reported the results of stress tests of Norwegian banks in its}

December 2009 Financial Stability Report. The baseline scenario corresponds to Norges Bank's baseline macroeconomic scenario described in Monetary Policy Report 3/09. The stress scenario assumes a relatively low-probability outcome - a very prolonged and weak recovery and a 20 percent fall in house prices (see text table). Banks incur increasing losses over the period 2010-12 due to depressed lending margins, low volume growth, and rising loan losses.

\begin{tabular}{|c|c|c|}
\hline & Baseline & Stress \\
\hline \multicolumn{3}{|c|}{ Mainland GDP growth (in percent, yoy) } \\
\hline 2009 & -1.0 & -1.3 \\
\hline 2010 & 2.8 & 0.0 \\
\hline 2011 & 3.2 & 0.8 \\
\hline 2012 & 2.6 & 1.6 \\
\hline \multicolumn{3}{|c|}{ House prices $1 /$} \\
\hline 2009 & 24.1 & 24.1 \\
\hline 2010 & 26.2 & 24.1 \\
\hline 2011 & 27.3 & 21.9 \\
\hline 2012 & 28.3 & 19.9 \\
\hline \multicolumn{3}{|c|}{ Banks' lending rates (percentage points) } \\
\hline 2009 & 4.4 & 4.4 \\
\hline 2010 & 4.3 & 4.2 \\
\hline 2011 & 5.4 & 5.0 \\
\hline 2012 & 6.3 & 5.9 \\
\hline \multicolumn{3}{|c|}{ Bank credit growth (in percent, yoy) } \\
\hline 2009 & 4.2 & 3.8 \\
\hline 2010 & 6.1 & 2.7 \\
\hline 2011 & 6.3 & 1.6 \\
\hline 2012 & 6.2 & 2.4 \\
\hline \multicolumn{3}{|c|}{ Return on assets (post-tax, in percent) $2 /$} \\
\hline 2009 & 0.6 & 0.5 \\
\hline 2010 & 0.5 & -0.1 \\
\hline 2011 & 0.6 & -0.6 \\
\hline 2012 & 0.6 & -0.8 \\
\hline \multicolumn{3}{|c|}{ Credit losses $3 /$} \\
\hline 2009 & 0.5 & 0.7 \\
\hline 2010 & 0.9 & 1.9 \\
\hline 2011 & 0.7 & 2.5 \\
\hline 2012 & 0.5 & 2.9 \\
\hline
\end{tabular}

Source: Norges Bank Financial Stability Report 2/09.

$1 /$ In thousands of Norwegian kroner per square meter.

2/ For the five largest Norwegian banks and Nordea Bank Norge.

3 / In percentage of exposure at default at beginning of year.

\footnotetext{
${ }^{1}$ Prepared by Jay Surti.
} 
Under the baseline scenario, tier I and equity ratios of the major banks are comfortably above 8 percent and 5 $1 \frac{1}{2}$ percent respectively (see table). More importantly, in the stress scenario, tier I ratios also are expected to remain well above the minimum requirement of 4 percent through 2012 (see last column). The second column in the table shows the capital ratios after the recent capital raising effort (by DnB NOR and Sparebank 1-SR). With the additional capital, tier I capital would remain above 6 percent of risk-weighted assets through the forecast horizon.

Norges Bank Stress Test Results 1/

\begin{tabular}{lccc}
\hline & Baseline & Stress & $\begin{array}{l}\text { Stress without } \\
\text { capital increase }\end{array}$ \\
\hline & & (in percentage points) \\
Tier I Ratio 2/ & & & \\
2009 & 9.5 & 9.6 & 8.3 \\
2010 & 9.7 & 9.0 & 7.8 \\
2011 & 9.6 & 7.6 & 6.4 \\
2012 & 9.5 & 6.0 & 4.8 \\
Equity Ratio 3/ & & & n.a. \\
2009 & 5.8 & 5.7 & n.a. \\
2010 & 5.6 & 5.6 & n.a. \\
2011 & 5.6 & 5.0 & n.a. \\
2012 & 5.6 & 4.0 & \\
\hline
\end{tabular}

Source: Norges Bank Financial Stability Report 2/09.

Notes:

1/ Aggregated results for 5 largest Norwegian banks and Nordea Bank Norge.

2/ Tier I regulatory capital-to-risk weighted assets.

$3 /$ Shareholder equity-to-total assets. 


\section{INTERNATIONAL MONETARY FUND}

\section{NORWAY}

\section{Staff Report for the 2009 Article IV Consultation-Informational Annex}

Prepared by the European Department

January 5, 2010

Contents

Page

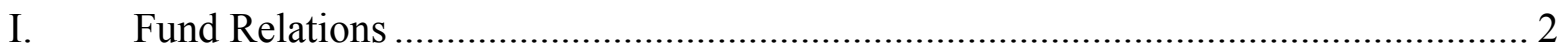




\section{APPENDIX I: FUND RELATIONS}

(As of November 30, 2009)

I. Membership Status: Joined 12/27/45; Article VIII

II. General Resources Account:

Quota

Fund holdings of currency

Reserve position in Fund

Lending to the Fund

III. SDR Department:

Net cumulative allocation

Holdings

SDR Million
$1,671.70$
$1,346.92$
324.79
78.40

SDR Million

$1,563.07$

$1,604.55$

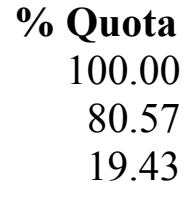

$\%$ Allocation

100.00

102.65

IV. Outstanding Purchases and Loans: None

V. Financial Arrangements: None

VI. Projected Obligations to Fund (SDR Million): ${ }^{1}$

\begin{tabular}{|l|r|r|r|r|r|}
\hline \multicolumn{5}{|c|}{ Forthcoming } \\
\hline & 2009 & 2010 & 2011 & 2012 & 2013 \\
\hline Principal & & & & & \\
\hline Charges/Interest & & 0.12 & 0.12 & 0.12 & 0.12 \\
\hline Total & & 0.12 & 0.12 & 0.12 & 0.12 \\
\hline
\end{tabular}

${ }^{1 /}$ When a member has overdue financial obligations outstanding for more than three months, the amount of such arrears will be shown in this section.

VII. Exchange Rate Arrangement: The present exchange rate arrangement for the krone is classified as an independent float, following the adoption of an inflation targeting regime on March 29, 2001. Norway maintains an exchange system that is free of restrictions on the making of payments and transfers for current international transactions, except for exchange restrictions maintained for security reasons that have been notified to the Fund pursuant to Decision No. 144-(51/52) (August 14, 1952).

Norges Bank has not intervened in the foreign exchange market since January 1999.

VIII. Article IV Consultation: Discussions for the 2009 Article IV Consultation were held in Oslo during November 12-23, 2009. The Staff Report will be considered by the Executive Board on January 22, 2010.

Norway has accepted the obligations of Article VIII, Sections 2, 3, and 4, of the Articles of Agreement. Norway subscribes to the Special Data Dissemination Standard and its economic statistics are satisfactory for surveillance purposes. Norway is a member of the 
European Economic Area, which provides for free movement of goods, services, labor, and capital with the European Union.

The authorities intend to publish this report.

IX. Technical Assistance: None (since 1998).

X. Resident Representative: None.

\section{Norway: Statistical Issues}

Norway maintains high standards in the provision of economic data, which are adequate for surveillance purposes. In some instances, including oil wealth, in particular, the GPFGlobal, and SOEs, transparency is very strong by international standards. For example, the Ministry of Petroleum and Energy and Statistics Norway regularly publish data on energy resources and activity while Norges Bank, the manager of the GPF-Global, regularly publishes detailed (quarterly and annual) reports on the portfolio and performance of the fund. The Ministry of Trade and Industry regularly publishes state ownership reports. 


\section{NORWAY: TABLE OF COMMON INDICATORS REQUIRED FOR SURVEILLANCE}

(As of December 17, 2009)

\begin{tabular}{|c|c|c|c|c|c|c|c|}
\hline & \multirow{2}{*}{$\begin{array}{c}\text { Date of } \\
\text { latest } \\
\text { observation }\end{array}$} & \multirow{2}{*}{$\begin{array}{l}\text { Date } \\
\text { received }\end{array}$} & \multirow{2}{*}{$\begin{array}{c}\text { Frequency } \\
\text { of } \\
\text { Data }^{6}\end{array}$} & \multirow{2}{*}{$\begin{array}{l}\text { Frequency } \\
\quad \text { of } \\
\text { Reporting }^{6}\end{array}$} & \multirow{2}{*}{$\begin{array}{l}\text { Frequency } \\
\text { of } \\
\text { publication }^{6}\end{array}$} & \multicolumn{2}{|c|}{ Memo Items: } \\
\hline & & & & & & $\begin{array}{c}\text { Data Quality - } \\
\text { Methodological } \\
\text { soundness } \\
\end{array}$ & $\begin{array}{c}\text { Data Quality - } \\
\text { Accuracy and } \\
\text { reliability } \\
\end{array}$ \\
\hline Exchange Rates & $\begin{array}{l}\text { Dec. } 16,20 \\
09\end{array}$ & $\begin{array}{l}\text { Dec. } 17,20 \\
09\end{array}$ & $\mathrm{D}$ & $\mathrm{D}$ & $\mathrm{D}$ & & \\
\hline $\begin{array}{l}\text { International Reserve Assets and Reserve Liabilities } \\
\text { of the Monetary Authorities }{ }^{1}\end{array}$ & Nov. 2009 & Dec. 2009 & M & M & M & & \\
\hline Reserve/Base Money & Oct. 2009 & Nov. 2009 & M & M & M & \multirow{4}{*}{$\mathrm{O}, \mathrm{O}, \mathrm{O}, \mathrm{LO}$} & \multirow{4}{*}{$\mathrm{O}, \mathrm{O}, \mathrm{O}, \mathrm{O}, \mathrm{O}$} \\
\hline Broad Money & Oct. 2009 & Nov. 2009 & M & M & M & & \\
\hline Central Bank Balance Sheet & Nov. 2009 & Dec. 2009 & M & M & M & & \\
\hline Consolidated Balance Sheet of the Banking System & Oct. 2009 & Nov. 2009 & M & M & M & & \\
\hline Interest Rates $^{2}$ & $\begin{array}{l}\text { Dec. } 16,20 \\
09\end{array}$ & $\begin{array}{l}\text { Dec. } 17,20 \\
09\end{array}$ & $\mathrm{D}$ & $\mathrm{D}$ & $\mathrm{D}$ & & \\
\hline Consumer Price Index & Nov. 2009 & Dec. 2009 & M & M & M & $\mathrm{O}, \mathrm{O}, \mathrm{O}, \mathrm{O}$ & $\mathrm{O}, \mathrm{O}, \mathrm{O}, \mathrm{O}, \mathrm{O}$ \\
\hline $\begin{array}{l}\text { Revenue, Expenditure, Balance and Composition of } \\
\text { Financing }{ }^{3} \text { - General Government }\end{array}$ & 2008 & May 2009 & A & A & A & \multirow[t]{2}{*}{$\mathrm{LO}, \mathrm{LNO}, \mathrm{O}, \mathrm{O}$} & \multirow[t]{2}{*}{$\mathrm{LO}, \mathrm{O}, \mathrm{O}, \mathrm{O}, \mathrm{LO}$} \\
\hline $\begin{array}{l}\text { Revenue, Expenditure, Balance and Composition of } \\
\text { Financing }{ }^{3} \text { - Central Government }\end{array}$ & Q3, 2009 & Oct. 2009 & Q & Q & Q & & \\
\hline $\begin{array}{l}\text { Stocks of Central Government and Central } \\
\text { Government-Guaranteed Debt }\end{array}$ & Q3, 2009 & Nov. 2009 & Q & Q & Q & & \\
\hline External Current Account Balance & Q3, 2009 & Dec. 2009 & Q & Q & Q & \multirow[b]{2}{*}{$\mathrm{O}, \mathrm{O}, \mathrm{O}, \mathrm{O}$} & \multirow[b]{2}{*}{$\mathrm{LO}, \mathrm{O}, \mathrm{O}, \mathrm{O}, \mathrm{LO}$} \\
\hline Exports and Imports of Goods and Services & Q3, 2009 & Dec. 2009 & $\mathrm{Q}$ & $\mathrm{Q}$ & $\mathrm{Q}$ & & \\
\hline GDP/GNP & Q3, 2009 & Dec. 2009 & Q & Q & Q & $\mathrm{O}, \mathrm{O}, \mathrm{O}, \mathrm{O}$ & $\mathrm{O}, \mathrm{O}, \mathrm{O}, \mathrm{O}, \mathrm{LO}$ \\
\hline Gross External Debt & Q3, 2009 & Nov. 2009 & Q & Q & $\mathrm{Q}$ & & \\
\hline
\end{tabular}

${ }^{1}$ Includes reserve assets pledged or otherwise encumbered as well as net derivative positions.

${ }^{2}$ Both market-based and officially-determined, including discount rates, money market rates, rates on treasury bills, notes and bonds.

${ }^{3}$ Foreign, domestic bank, and domestic nonbank financing.

${ }^{4}$ The general government consists of the central government, including National Insurance Scheme, and local governments.

${ }^{5}$ Including currency and instrument composition.

${ }^{6}$ Daily (D), Weekly (W), Monthly (M), Quarterly (Q), Annually (A), Irregular (I); Not Available (NA).

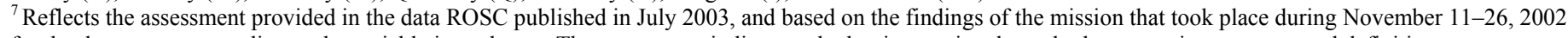
for the dataset corresponding to the variable in each row. The assessment indicates whether international standards concerning concepts and definitions, scope, classification/sectorization, and basis for recording are fully observed (O), largely observed (LO), largely not observed (LNO), or not observed (NO).

${ }^{8}$ Same as footnote 7 , except referring to international standards concerning source data, statistical techniques, assessment and validation of source data, assessment and validation of intermediate data and statistical outputs, and revision studies. 


\section{INTERNATIONAL MONETARY FUND}

Public Information Notice (PIN) No. 10/14

FOR IMMEDIATE RELEASE

January 27, 2010
International Monetary Fund

$70019^{\text {th }}$ Street, NW

Washington, D. C. 20431 USA

\section{IMF Executive Board Concludes 2009 Article IV Consultation with Norway}

On January 22, 2010, the Executive Board of the International Monetary Fund (IMF) concluded the Article IV consultation with Norway. ${ }^{1}$

\section{Background}

Norway was affected by the global financial crisis, but less severely than most other advanced economies. Falling asset prices and a sharp rise in uncertainty pulled down private demand in the second half of 2008. However, the ensuing recession was comparatively shallow, with mainland GDP already returning to growth in the second quarter of 2009. Unemployment has increased only modestly to about 3 percent and consumer confidence has recovered strongly, in sync with a rebound in the housing market. Still, the economic downturn has reduced earlier pressures on capacity constraints. Wage growth has eased, and $\mathrm{CPI}$ inflation has fallen below the target.

The authorities' response to the slowdown was forceful and effective. Norges Bank cut interest rates by a cumulative 450 basis points through June 2009. At the same time, a large fiscal stimulus was implemented and a number of timely measures to support financial stability were put in place. Norway's resilience has also been underpinned by buoyant activity in the offshore hydrocarbon sector, limited dependence on the hardest-hit segments of global manufacturing, and the temporary depreciation of the krone in late 2008.

\footnotetext{
${ }^{1}$ Under Article IV of the IMF's Articles of Agreement, the IMF holds bilateral discussions with members, usually every year. A staff team visits the country, collects economic and financial information, and discusses with officials the country's economic developments and policies. On return to headquarters, the staff prepares a report, which forms the basis for discussion by the Executive Board. At the conclusion of the discussion, the Managing Director, as Chairman of the Board, summarizes the views of Executive Directors, and this summary is transmitted to the country's authorities. An explanation of any qualifiers used in summings up can be found here: http://www.imf.org/external/np/sec/misc/qualifiers.htm.
} 
The Norwegian financial system has held up well. The authorities' stepped-up liquidity support after Lehman's bankruptcy helped contain the effect of the global crisis on domestic financial institutions. Norwegian banks did not face solvency issues, the rise in non-performing loans has been limited so far, and profitability has strengthened in the course of 2009. Credit conditions have recently started to ease, after a sharp tightening in late 2008. Banks' good performance reflects low exposure to toxic assets, a robust domestic economy, and a relatively conservative prudential framework. Still, credit risks remain elevated as the banking system has large credit exposures to the shipping and commercial real estate sectors.

Looking ahead, the economic recovery is expected to continue, with private domestic demand progressively replacing public spending as the main driver of growth. Private consumption is projected to strengthen further as households continue to benefit from low interest rates, limited unemployment, and improved asset valuations. A turn in the inventory cycle should also support activity, while fixed investment may remain subdued somewhat longer, and net exports are likely to weaken. On balance, mainland GDP is expected to grow by $2 \frac{1}{4}$ percent in 2010 . Near-term inflation should be kept in check by slower wage growth and regained krone strength, although tight cyclical conditions are set to reemerge sooner than in many other advanced economies. The outlook for Norway's economy is, however, subject to significant uncertainty related to future developments in global demand, commodity prices, and the exchange rate.

\section{Executive Board Assessment}

Directors observed that Norway entered the global financial crisis from a strong macroeconomic position and has faced a relatively mild downturn. The economy's resilience has been bolstered by effective fiscal and monetary stimulus, a favorable industrial structure, and a relatively stable financial system. Directors expected the economic recovery to continue, while recognizing that uncertainty about the global economic environment posed a risk to the outlook. The near-term policy challenge will be to manage the gradual withdrawal of stimulus as the recovery takes hold.

Directors considered the large fiscal stimulus implemented in 2009 timely and well designed. However, they expressed concern that many of the temporary spending measures introduced in 2009 have been replaced by more permanent expenditure increases in the 2010 budget. Given the relatively limited slack in the economy and the high non-oil deficit, Directors called for strict expenditure control in the 2010 budget implementation.

Directors welcomed the authorities' intention to steadily reduce the non-oil deficit to the 4-percent target as the economic recovery takes hold. Fiscal consolidation will reaffirm commitment to Norway's fiscal guidelines, help preserve competitiveness, and restore flexibility to deal with future adverse shocks. Directors called for early identification of concrete measures to help enhance the credibility of consolidation plans, and supported the authorities' emphasis on expenditure-side adjustment. They viewed the fiscal guidelines as appropriate but stressed that the flexibility to temporarily deviate from the fiscal target should be used symmetrically.

Directors commended the authorities' pension reform, which aims to encourage longer working lives and contain the rise of pension outlays by tying benefits to demographic developments. The reform should be supplemented by concrete actions to reduce the high 
inflows into sickness and disability benefit schemes, with measures enhancing the incentives of both employees and employers.

Directors noted that aggressive monetary policy easing through mid-2009 has played an important role in mitigating the domestic recession. The moderate interest rate hikes in late 2009 are an appropriate response to the stabilization of the situation. Looking ahead, the strengthening outlook, a relatively tight labor market, and the macroeconomic risks implied by strong house price appreciation all point to the need for a gradual further withdrawal of the extraordinary monetary stimulus.

Directors considered that Norway's financial sector has weathered the crisis well but vulnerabilities remain. They welcomed the authorities' targeted measures to support banking sector liquidity and improve the functioning of the corporate bond market, which helped preserve financial stability during the crisis. Recent efforts to strengthen banks' capital buffers, including through capital injections from the State Finance Fund, will allow banks to continue lending to creditworthy customers.

Directors saw scope for a further strengthening of Norway's general prudential framework. Priorities in this area are strengthening the management of liquidity risks and the adoption of measures to limit excessive balance sheet growth. To contain the systemic risk associated with large household debt and high loan-to-value mortgages, Directors recommended reducing tax subsidies for housing investment and adopting targeted macroprudential measures. While regulatory improvements should be based on international practices, Directors pointed out that close coordination with Norway's neighbors could be used to ensure higher common standards across the Nordic financial region as appropriate.

Public Information Notices (PINs) form part of the IMF's efforts to promote transparency of the IMF's views and analysis of economic developments and policies. With the consent of the country (or countries) concerned, PINs are issued after Executive Board discussions of Article IV consultations with member countries, of its surveillance of developments at the regional level, of post-program monitoring, and of ex post assessments of member countries with longer-term program engagements. PINs are also issued after Executive Board discussions of general policy matters, unless otherwise decided by the Executive Board in a particular case. The staff report (use the free Adobe Acrobat Reader to view this pdf file) for the 2009 Article IV Consultation with Norway is also available. 
Norway: Selected Economic and Social Indicators, 2004-10

\begin{tabular}{|c|c|c|c|c|c|c|c|}
\hline & 2004 & 2005 & 2006 & 2007 & 2008 & $\begin{array}{l}2009 \\
\text { Proj. }\end{array}$ & $\begin{array}{l}2010 \\
\text { Proj. }\end{array}$ \\
\hline \multicolumn{8}{|l|}{ Real economy (change in percent) } \\
\hline Real GDP & 3.9 & 2.5 & 2.1 & 2.7 & 1.8 & -1.1 & 1.2 \\
\hline Real mainland GDP 1/ & 4.4 & 4.4 & 4.6 & 5.6 & 2.2 & -1.2 & 2.3 \\
\hline Domestic demand & 6.7 & 5.5 & 5.6 & 5.0 & 2.5 & -2.3 & 2.4 \\
\hline Private consumption & 5.6 & 4.0 & 4.8 & 5.4 & 1.3 & -0.1 & 3.3 \\
\hline Private mainland fixed investment & 11.3 & 15.9 & 12.0 & 17.2 & 0.1 & -15.4 & -3.2 \\
\hline Unemployment rate (percent of labor force) & 4.5 & 4.6 & 3.4 & 2.5 & 2.6 & 3.1 & 3.7 \\
\hline Output gap (mainland economy, - = output below potential) & -1.9 & -0.6 & 1.0 & 3.5 & 3.1 & -0.3 & -0.1 \\
\hline $\mathrm{CPI}$ (average) & 0.5 & 1.5 & 2.3 & 0.7 & 3.8 & 2.2 & 1.4 \\
\hline CPI (end of period) & 1.1 & 1.8 & 2.2 & 2.8 & 2.1 & 2.0 & 1.6 \\
\hline Gross national saving (percent of GDP) & 32.7 & 37.4 & 39.2 & 39.1 & 41.6 & 35.9 & 36.7 \\
\hline Gross domestic investment (percent of GDP) & 20.0 & 21.2 & 22.0 & 23.6 & 22.7 & 21.8 & 20.8 \\
\hline \multicolumn{8}{|l|}{ Public finance } \\
\hline \multicolumn{8}{|l|}{ Central government (fiscal accounts basis) $2 /$} \\
\hline Overall balance (percent of GDP) & 7.1 & 10.8 & 14.4 & 13.9 & 15.9 & 6.2 & 2.6 \\
\hline \multirow{2}{*}{$\begin{array}{l}\text { Structural non-oil balance (percent of mainland trend GDP) 3/ } \\
\text { in percent of Government Pension Fund-Global capital 4/ }\end{array}$} & -3.2 & -3.4 & -3.4 & -3.5 & -4.2 & -7.2 & -7.8 \\
\hline & -5.2 & -4.8 & -3.7 & -3.2 & -3.6 & -5.7 & -5.7 \\
\hline \multicolumn{8}{|l|}{ General government (national accounts basis, percent of GDP) $5 /$} \\
\hline Overall balance & 11.1 & 15.1 & 18.5 & 17.8 & 18.7 & 7.3 & 8.5 \\
\hline Net financial assets & 86.5 & 99.6 & 109.4 & 115.1 & 112.9 & 134.7 & 136.2 \\
\hline of which: Capital of Government Pension Fund-Global & 58.3 & 71.8 & 82.5 & 88.8 & 89.4 & 109.5 & 112.6 \\
\hline \multicolumn{8}{|l|}{ Money and credit (end of period, 12-month percent change) 6/ } \\
\hline Broad money, M2 & 7.5 & 11.7 & 13.7 & 16.7 & 3.7 & 1.5 & $\ldots$ \\
\hline Domestic credit, C2 & 8.6 & 13.2 & 14.3 & 14.0 & 12.0 & 5.1 & $\cdots$ \\
\hline \multicolumn{8}{|l|}{ Interest rates (year average, in percent) } \\
\hline Three-month interbank rate & 2.0 & 2.2 & 3.1 & 5.0 & 6.2 & 2.5 & $\ldots$ \\
\hline Ten-year government bond yield & 4.4 & 3.7 & 4.1 & 4.8 & 4.5 & 4.0 & $\ldots$ \\
\hline \multicolumn{8}{|l|}{ Balance of payments (percent of mainland GDP) } \\
\hline Current account balance & 16.4 & 21.8 & 23.5 & 18.6 & 26.0 & 18.7 & 21.7 \\
\hline Balance of goods and services & 17.4 & 22.1 & 24.7 & 20.2 & 26.8 & 17.5 & 20.9 \\
\hline Net exports of oil and gas & 24.8 & 29.3 & 31.4 & 27.5 & 33.7 & 24.1 & 27.6 \\
\hline Exports of goods and services (volume change in percent) & 1.1 & 1.1 & 0.0 & 2.3 & 0.9 & -5.2 & 0.2 \\
\hline Imports of goods and services (volume change in percent) & 8.8 & 8.7 & 8.4 & 8.6 & 2.2 & -10.5 & 3.5 \\
\hline Terms of trade (change in percent) & 7.7 & 15.6 & 11.9 & -1.6 & 12.2 & $\ldots$ & $\ldots$ \\
\hline International reserves (end of period, in billions of US dollars) & 44.4 & 47.0 & 56.5 & 61.1 & 51.1 & $\cdots$ & $\cdots$ \\
\hline \multicolumn{8}{|l|}{ Fund position (as of November 30,2009 ) } \\
\hline Holdings of currency (percent of quota) & & & & & & & 80.6 \\
\hline Holdings of SDR (percent of allocation) & & & & & & & 102.7 \\
\hline Quota (SDR millions) & & & & & & & 671.7 \\
\hline \multicolumn{8}{|l|}{ Exchange rates (end of period) } \\
\hline Exchange rate regime & & & & & \multicolumn{3}{|c|}{ Free float } \\
\hline Bilateral rate (NOK/USD) 7/ & 6.0 & 6.8 & 6.3 & 5.4 & 7.0 & 5.9 & $\ldots$ \\
\hline Nominal effective rate $(2000=100) 6 /$ & 110.6 & 111.5 & 110.9 & 116.5 & 100.7 & 107.9 & $\ldots$ \\
\hline Real effective rate $(2000=100) 6 /$ & 109.7 & 110.7 & 110.3 & 115.3 & 100.4 & 107.1 & $\cdots$ \\
\hline \multicolumn{8}{|l|}{ Social Indicators (reference year): } \\
\hline \multirow{2}{*}{\multicolumn{8}{|c|}{$\begin{array}{l}\text { Per capita GDP (2008): } \$ 96,100 \text {; Income distribution (ratio of after-tax income received by top and bottom } 20 \text { th percentile, } 2007 \text { ): } 3.4 \text {; } \\
\text { At-risk-of-poverty rate (2007): } 11.7 \text {; Life expectancy at birth (2008): male: } 78.3 \text {, female: } 82.9 \text {. } \\
\text { Population (2008): } 4.69 \text { million; Population density (2008): } 14.5 \text { inhabitants per square km. }\end{array}$}} \\
\hline & & & & & & & \\
\hline \multicolumn{8}{|c|}{$\begin{array}{l}\text { Sources: Ministry of Finance; Norges Bank; Statistics Norway; International Financial Statistics; and IMF staff estimates and projections. } \\
\text { 1/ Excludes items related to petroleum exploitation and ocean shipping. } \\
\text { 2/ Projections based on authorities' } 2010 \text { budget. } \\
\text { 3/ Authorities' key fiscal policy variable; excludes oil-related revenue and expenditure, GPF-G income, as well as cyclical effects. } \\
\text { 4/ Over-the-cycle deficit target: } 4 \text { percent } \\
\text { 5/ Staff projections, incorporating higher } 2010 \text { oil price assumption than the authorities' } 2010 \text { budget. } \\
\text { 6/ } 2009 \text { data as of end-October. } \\
\text { 7/ } 2009 \text { data as of December } 18,2009 .\end{array}$} \\
\hline
\end{tabular}




\section{Statement by Jarle Bergo, Executive Director for Norway January 22, 2010}

On behalf of my Norwegian authorities, I would like to thank staff for a thorough and well-written report on the Norwegian economy. My authorities broadly concur with staff's analysis.

\section{Economic developments}

As noted by staff, the Norwegian economy has been relatively mildly hit by the financial crisis and the subsequent contraction in world economic activity. Mainland-GDP is estimated to have fallen by just over 1 percent in 2009, while the authorities project growth in 2010 to be just above 2 percent - around $1 / 2$ percentage point below the trend rate of growth. Employment has declined considerably over the past year, but in combination with a fall in labor supply, the increase in unemployment has been moderate. The unemployment rate is currently 3.2 percent (September-November 2009), up from the very low level of $2 \frac{1}{2}$ percent in 2008 .

Underlying inflation is currently close to the inflation target, but is expected to fall somewhat in the coming months, partly as a result of weak international price impulses and a stronger Norwegian currency. Wage growth is moderated by bleak profits in the competitive sector, which traditionally provide a norm for wage growth in other sectors of the economy.

\section{Fiscal policy}

The Norwegian fiscal framework aims at a gradual increase in the spending of petroleum revenues to a sustainable level. Over time the structural non-oil deficit shall correspond to the expected annual real rate of return on the Government Pension Fund - Global (GPF), estimated at 4 percent. In the shorter run, the guidelines also allow fiscal policy to be used actively to counter fluctuations in economic activity. In a cyclical expansion, fiscal policy restraint relative to the 4 percent spending rule is called for, whereas in a cyclical downturn, higher spending of oil revenues is justified to stabilize the economy.

After the Lehman Brothers crisis in September 2008 there was a dramatic change in the outlook for the Norwegian economy. It was necessary to draw on both monetary and fiscal policy to prevent too strong a downturn in mainland activity, and action was also taken through targeted measures to reduce the problems in financial markets.

An extraordinary January 2009 stimulus package increased the fiscal impulse from 0.7 to 2.4 percent of mainland GDP. The January package was mainly targeted at public infrastructure (both maintenance and investments), supplemented by temporary tax reductions for businesses. In May 2009, in the Revised National Budget, fiscal policy was made even more expansionary, mainly as a result of higher estimated growth in expenditures in the social security system and estimated lower dividends from stateowned companies. In the Final Budget Revision for 2009, in late November, the 
estimated public spending was revised somewhat down and structural taxes somewhat up, resulting in a downward revision of the estimated fiscal impulse in 2009 from 3.0 to 2.7 percent of mainland GDP.

Uncertainty about future economic developments was gradually reduced in the course of the summer and autumn of 2009, but risks were still pronounced when the 2010 Budget was presented in early October 2009. Thus, the 2010 Fiscal Budget included a further $1 / 2$ percentage point expansionary fiscal impulse.

The extraordinary fiscal escalation to counteract the effects of the financial crisis and the global recession has brought spending of petroleum revenues to a high level. The structural, non-oil deficit for 2010 is estimated at NOK 148.5 billion, or 7.8 percent of trend GDP for mainland Norway. The 2010-figure is NOK 45 billion above the 4 percent path and in line with the expected real return on the Fund for 2018.

The Norwegian Government has stated that spending of petroleum revenues should be brought back to the 4-percent path as the economic outlook brightens and economic growth picks up again. In this way fiscal policy leeway can be restored, and public finances will be better bolstered to meet the expenditure increases that will accompany an aging population. Furthermore, a return to the 4 percent path will ease pressure on monetary policy, reducing the risk of a too strong exchange rate for mainland industries exposed to international competition.

The fiscal guidelines ensure that the petroleum wealth will make a lasting contribution to financing public welfare schemes, in benefit of today's young people and future generations. The market value of the GPF, including both the international and domestic part, is estimated at NOK 2700 billion or 115 percent of GDP at the end of 2009, making it one of the world's largest sovereign wealth funds. Nevertheless, the capital in the Fund is considerably lower than the old age pension obligations under the National Insurance Scheme. Long-term budget challenges, due to future increases in pension costs in the National Insurance Scheme and other age-related expenses, underline the need for a prudent fiscal policy and continued reform to curb growth in public expenditures.

\section{Monetary policy}

The Norwegian authorities generally concur with staff's assessment of monetary policy. The strengthening macroeconomic outlook calls for a gradual move to a tighter monetary policy stance. As markets returned to normal, most of the unconventional monetary policy measures were phased out during autumn 2009. Norges Bank is one of the first central banks to start raising policy rates, having increased rates by a total of $50 \mathrm{bp}$ in October and December to 1.75 percent. According to the latest assessments by Norges Bank's Executive Board, the key policy rate should be in the interval of 1.25 percent to 2.25 percent in the period up to the publication of the next Monetary Policy Report on March 24, 2010. After that, Norges Bank projects the key policy rate to be raised gradually to around 2.75 percent by the end of the year. 
The Bank has emphasized that there is considerable uncertainty surrounding the interest rate projections. Even though the upturn seems to have gained firmer footing both internationally and in Norway, the pace of the recovery is still uncertain. Higher capacity utilization or a weaker krone - for instance as a result of falling oil prices - may on the one hand result in higher than projected inflation. On the other hand, inflation may be lower than expected if the krone remains strong or productivity picks up rapidly. In an environment of very low interest rates internationally, higher interest rates in Norway may lead to an appreciation of the krone. In its latest communications, Norges Bank has pointed out that "should the krone appreciate considerably more than projected, the interest rate may be increased to a lesser extent or later than currently envisaged."

The authorities take note of staff's assessment of the real effective exchange rate. Calculations done by the IMF staff suggest a slight overvaluation of the krone based on conservative assumptions about the petroleum wealth. Such calculations are, however, uncertain and sensitive to small changes in the assumptions. To conclude with any degree of confidence that the real exchange rate is misaligned, the actual rate has to deviate significantly from the estimated rate.

Measured in relative wages in a common currency, the real effective krone exchange rate has strengthened considerably in recent years and is now approximately 15 percent higher than its long term average.

\section{Financial stability}

The authorities agree with staff that "the financial system in Norway has weathered the global financial crisis well, but vulnerabilities remain". Norwegian financial institutions had limited exposure to risky assets, partly due to sound regulation. Extensive monetary and fiscal policy measures have limited the decline in activity and bank losses, and it seems unlikely that the financial crisis will lead to a solvency crisis in Norwegian banks. Banks are now bolstering their Tier I capital, which will make it easier for them to procure new loans, bear losses, and provide credit.

Norwegian banks still face challenges. They have to take account of credit risk on loans to the commercial property and shipping sectors. Also, the household debt burden (debt as a percentage of disposable income) is high and is expected to edge up. Banks' loan losses are likely to increase. However, unless the Norwegian economy is exposed to new severe shocks, bank results are expected to remain favorable. Stress tests indicate that banks will satisfy the capital adequacy requirements also in a case where economic developments prove to be considerably worse than expected.

The crisis has demonstrated the importance of sound financial market regulation and supervision. Norway has, inter alia, emphasized uniform capital requirements for all types of financial institutions, conservative treatment of subsidiaries, off balance sheet assets and securitization, and a single supervisor which combines supervision of individual entities with macro-economic surveillance. A good deposit insurance scheme helped avoid run on banks, and it was not necessary to increase the coverage level or provide a 
government guarantee for banks. Further strengthening of the prudential framework is foreseen in line with new recommendations from international fora like the BIS and through implementation of new EU provision through the EEA Agreement. The scope for Nordic cooperation on stricter prudential rules is also explored.

\section{Pension reform and benefit entitlements}

Fundamentals in the Norwegian labor market are healthy with low unemployment and high participation rates, especially among women and older workers. A key to sustainable public finances in the long run is to keep labor supply high or preferably to increase it. This may be challenging with an ageing population and an increasing inflow into sick leave and disability schemes.

The Norwegian authorities share staff's concern about the high proportion of the working population on sick leave, disability and other health-related benefits, and agree that measures should be taken to bring these numbers down. Together with the social partners, the Government is currently working to revise the existing agreement on sick leave that was introduced in 2001. The intention is to reduce the actual absentee level and curb expenditure growth. Both administrative measures and extended employer co-financing are being discussed.

The Norwegian pension system is undergoing fundamental reform. An important reform element is the introduction, in the National Insurance Scheme from January 1, 2011, of a flexible retirement age from 62 years which is actuarially neutral with respect to retirement age. A similar reform of the early retirement system in the private sector is almost completed. However, some elements of the reform are still to be decided on. In particular, that includes necessary adjustments of disability pensions, where the Government will present a proposal to Parliament this year based on the Disability Commission's report from 2007. 